Published in final edited form as:

J Med Chem. 2015 November 12; 58(21): 8694-8712. doi:10.1021/acs.jmedchem.5b01330.

\title{
Phenyl Ether- and Aniline-Containing 2-Aminoquinolines as Potent and Selective Inhibitors of Neuronal Nitric Oxide Synthase
}

\author{
Maris A. Cinelli ${ }^{1}$, Huiying $\mathrm{Li}^{2}$, Anthony V. Pensa ${ }^{1}$, Soosung Kang ${ }^{1}$, Linda J. Roman ${ }^{3}$, Pavel

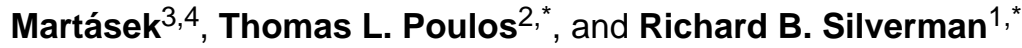 \\ ${ }^{1}$ Department of Chemistry, Department of Molecular Biosciences, Chemistry of Life Processes \\ Institute, Center for Molecular Innovation and Drug Discovery, Northwestern University, 2145 \\ Sheridan Road, Evanston, Illinois 60208-3113, United States \\ ${ }^{2}$ Departments of Molecular Biology and Biochemistry, Pharmaceutical Sciences, and Chemistry, \\ University of California, Irvine, California 92697-3900, United States \\ ${ }^{3}$ Department of Biochemistry, University of Texas Health Science Center, San Antonio, Texas \\ 78384-7760, United States \\ ${ }^{4}$ Department of Pediatrics, 1st Faculty of Medicine, Charles University, Prague and BIOCEV, \\ Czech Republic
}

\begin{abstract}
Excess nitric oxide (NO) produced by neuronal nitric oxide synthase (nNOS) is implicated in neurodegenerative disorders. As a result, inhibition of nNOS and reduction of NO levels is desirable therapeutically, but many nNOS inhibitors are poorly bioavailable. Promising members of our previously reported 2-aminoquinoline class of nNOS inhibitors, although orally bioavailable and brain-penetrant, suffer from unfavorable off-target binding to other CNS receptors, and they resemble known promiscuous binders. Rearranged phenyl ether- and anilinelinked 2-aminoquinoline derivatives were therefore designed to a) disrupt the promiscuous binding pharmacophore and diminish off-target interactions, and b) preserve potency, isoform selectivity, and cell permeability. A series of these compounds was synthesized and tested against purified nNOS, endothelial NOS (eNOS), and inducible NOS (iNOS) enzymes. One compound, 20, displayed high potency, selectivity, and good human nNOS inhibition, and retained some permeability in a Caco-2 assay. Most promisingly, CNS receptor counterscreening revealed this rearranged scaffold significantly reduces off-target binding.
\end{abstract}

\footnotetext{
*To whom correspondence should be addressed. Tel.:+1 847491 5653; Fax: +1 8474917713 (R.B.S.); Tel.:+1 9498247020. (T.L.P.).Agman@chem.northwestern.edu (R.B.S), poulos@uci.edu (T.L.P).

Supporting Information. Crystallographic data collection and refinement statistics for rat and human nNOS, eNOS, and nNOS double mutant crystal structures; synthesis and analytical data for compounds 28-59; and rnNOS-10, eNOS-7, -8, -17, $\mathbf{- 2 0}$, and hnNOS-17 crystal structures (Figures S1-S5).

PDB ID Codes. PDB codes for X-ray crystal structures described in this study have been deposited in the Protein Data Bank under the following accession codes: 5AD4, 5AD5, 5AD6, 5AD6, 5AD8, 5AD9, 5ADA, 5ADB, 5ADC, 5ADD, 5ADE, 5ADF, 5ADG, 5ADI, $5 \mathrm{ADJ}, 5 \mathrm{ADK}, 5 \mathrm{ADL}, 5 \mathrm{ADN}, 5 \mathrm{FJ} 2$, and $5 \mathrm{FJ} 3$.
} 


\section{Introduction}

Neurodegenerative disorders, such as Alzheimer's, Parkinson's, and Huntington's diseases, amyotrophic lateral sclerosis (ALS), and others, are diseases where the structure and function of neurons gradually deteriorate, leading to the motor, cognitive, and psychological difficulties associated with these disorders. Neuronal damage also occurs in head trauma, cerebral palsy, stroke, and ischemic events. With the world's increasingly aged population, the incidence of neurodegenerative disorders is also increasing, and, with most treatments limited to palliative care, the development of new therapeutics is of utmost importance.

A target receiving considerable attention is neuronal nitric oxide synthase (nNOS). ${ }^{1}$ Nitric oxide (NO), an important second messenger, is produced by three nitric oxide synthase (NOS) enzymes: inducible nitric oxide synthase (iNOS), required for immune response activation, endothelial nitric oxide synthase (eNOS), which regulates blood pressure and vascular tone, and nNOS, necessary for neuronal signaling. ${ }^{2}$ If nNOS is overexpressed or overactive in neuronal tissue, however, the excess $\mathrm{NO}$, especially if converted to peroxynitrite, can cause free radical damage to cellular structures and protein nitration, which can lead to misfolding and aggregation. ${ }^{3,4}$ Abnormally high levels of nNOS and NO have therefore been associated with or implicated in numerous neurodegenerative disorders, $, 5,6,8$ making nNOS inhibition a desirable therapeutic avenue for treatment or prevention of these conditions. $.9,10,11$

Nitric oxide synthases are unique among mammalian enzymes in that they are homodimers requiring five cofactors to function: flavin adenine dinucleotide (FAD), flavin mononucleotide (FMN), and reduced nicotinamide adenine dinucleotide phosphate (NADPH), found in each monomer's reductase domain, and (6R)-5,6,7,8tetrahydrobiopterin $\left(\mathrm{H}_{4} \mathrm{~B}\right)$ and the final electron acceptor, heme, which bind in each monomer's oxygenase domain along with the substrate, L-arginine. Between the two domains lies a flexible region where calmodulin binds when activated by calcium ion, and electron flow proceeds from one monomer's reductase domain to the other's oxygenase domain, ${ }^{12}$ where NO is produced as L-arginine is oxidized to L-citrulline. ${ }^{13}$

One important challenge in the design of nNOS inhibitors is that eNOS and iNOS, in sequence and overall structure, are nearly identical to nNOS, especially in their active site residues. ${ }^{14,15}$ Nonselective NOS inhibition is potentially dangerous: iNOS inhibition could interfere with immune activation, while eNOS inhibition can cause severe hypertension and other cardiovascular liabilities. ${ }^{16}$ Additionally, many nNOS inhibitors are mimics of Larginine and thus have high basicity and polarity, large total polar surface area (tPSA), and many hydrogen bond donors, all of which hinder inhibitors' blood-brain barrier (BBB) penetration and diminish therapeutic use. ${ }^{17}$

In 2014, we reported a series of 2-aminoquinolines as competitive nNOS inhibitors. ${ }^{18}$ Two compounds, 1 and 2 (Figure 1), were considered promising candidates for further development because of their high potency and selectivity over iNOS and eNOS. These compounds are permeable in a Caco-2 assay, and $\mathbf{1}$ displayed good oral bioavailability and brain permeation in mice. Although only modestly potent in vivo, 2 also inhibited nNOS in 
rat brain homogenates and in the brains of live rats. Despite their promise, $\mathbf{1}$ and $\mathbf{2}$ have major disadvantages. Compound $\mathbf{2}$ has a poor safety profile in rats, displaying toxic side effects at the doses required for effective nNOS inhibition. Furthermore, a counterscreen against a panel of relevant CNS targets and receptors performed by the Psychoactive Drug Screening Program (PDSP) ${ }^{19}$ revealed $\mathbf{1}$, and especially $\mathbf{2}$, are promiscuous binders with strong $(<100 \mathrm{nM})$ affinities for serotonin, opioid, and histamine receptors, as well as for the dopamine and norepinephrine transporters, which could cause unfavorable side effects. Additionally, compounds $\mathbf{1}$ and $\mathbf{2}$ are quite time consuming to synthesize (12 steps). Because of these problems, we chose to investigate alternative aminoquinoline-containing scaffolds for nNOS inhibition.

Interestingly, the literature revealed that compounds such as ketanserin, haloperidol, and risperidone, which also bind to multiple, similar CNS targets, have overall structural motifs in common with $\mathbf{1}$ and $\mathbf{2}$ - two hydrophobic or aromatic exteriors (one, often halogenated), joined by an interior alkylamine linker, a pharmacophore (Figure 2A) that appears to "stick" to GPCRs and other CNS targets. ${ }^{20}$

Lowe and colleagues at $\mathrm{Pfize}^{21}$ reported the structure of $\mathbf{3}$, a potent nNOS inhibitor with very high affinity for dopamine and serotonin receptors. Removal of the exterior hydrophobic group diminished off-target binding, and when an exterior polar amine was attached to an interior hydrophobic group (such as in $\mathbf{4}$ and 5) higher potency and isoform selectivity resulted. ${ }^{22,23}$ Similar exterior polar amines (especially $N$-methyl and $\mathrm{N}, \mathrm{N}$ dimethylamines) were also effective in conferring potency and selectivity of NeurAxon's thiophenecarboximidamides. ${ }^{24,25}$

Design of an analogous "inverted" aminoquinoline-containing compound (Figure 2B) resulted in $\mathbf{6}$, with the halves of the molecule joined by a phenyl ether, the same as in $\mathbf{4}$ and 5. We hypothesized that in addition to reducing off-target binding, this structural rearrangement could have additional benefits. First, the external amine of $\mathbf{6}$ could potentially form interactions in various spots peripheral to the nNOS active site such as Asp597, the $\mathrm{H}_{4} \mathrm{~B}$ site, or residues of the substrate access channel hydrophobic pocket, all of which have been shown to play significant roles in conferring potency or isoform selectivity. $26,27,28$ Second, the predicted physicochemical properties of $\mathbf{6}$ are similar to those of $\mathbf{1}$ and $\mathbf{2}$ (CLogP: $2-4,<7$ rotatable bonds, TPSA $<80 \AA^{2}$, and $<4$ hydrogen-bond donors), making it plausible that the cellular permeability of $\mathbf{1}$ and $\mathbf{2}$ could be preserved.

In addition to 6, we designed and synthesized a small library of related compounds (7-12, Figure 3); all were assayed against purified rat nNOS, murine iNOS, and bovine eNOS. Encouraged by the potency and isoform selectivity of $\mathbf{8}$ and $\mathbf{9}$, different modifications were performed to optimize the structure and examine the SAR. First, $\mathbf{1 3}$ and $\mathbf{1 4}$ were synthesized to investigate if longer tail lengths could provide additional or enhanced beneficial contacts with the enzyme. Second, although $\mathbf{8}$ and $\mathbf{9}$ have the amine-containing moiety located meta to the phenyl ether, para-substituted compounds $\mathbf{1 5}$ and $\mathbf{1 6}$ were also prepared to investigate the role that different ring substitution patterns may play. Third, we reasoned that bioisosteric replacement of the phenyl ether with an aniline (17 and 18) might introduce 
another contact in the region near the heme propionates, resulting in greater affinity for nNOS.

Finally, we performed specific, structure-based optimizations to improve the potency and selectivity of lead 9. X-ray crystallography indicated that the center aryl rings of $\mathbf{8}$ and $\mathbf{9}$ abut two residues, Tyr706 and Asn569. We hypothesized that introduction of halogens para to the phenyl ether linkage, as in 19 and 20, could provide additional van der Waals interactions with Tyr706 or the surrounding hydrophobic structures. Likewise, by converting the phenyl ring to a pyridine (21), a hydrogen bond or polar contact could potentially form between the pyridine nitrogen and the side chain of Asn569. We also proposed that contacts might be made with other residues of the hydrophobic pocket (such as Met336 and Leu337) by placing a methyl group alpha to the exterior amine group of $\mathbf{9}$ (to yield 22). All compounds were assayed against purified rat nNOS, and select compounds were assayed against eNOS, iNOS, and human nNOS, for cellular permeability in a Caco-2 model, and against a panel of CNS targets in the PDSP to assess their off-target binding.

\section{Chemistry}

Previously, 7-substituted-2-aminoquinolines were prepared via readily accessible chloroquinoline $\mathbf{2 3}^{18,29}$ (Scheme 1) by performing a Korodi amidation ${ }^{30}$ to produce 2acetamidoquinoline 25. Unfortunately, this procedure gives irreproducible yields and is not readily amenable to scale-up. Smith et al. ${ }^{31}$ reported the palladium-catalyzed amination of 2chloroquinolines using LHMDS as both an ammonia surrogate and base; applying this procedure to $\mathbf{2 3}$ afforded 2-aminoquinoline $\mathbf{2 4}$ in nearly quantitative yield on a multigram scale. Treatment with $\mathrm{N}$-acetylimidazole in refluxing THF afforded 25, and free-radical bromination (as previously reported) yielded versatile bromide $\mathbf{2 6}$.

The phenol and aniline halves were then prepared. To prepare 6 (Scheme 2A), 3methoxyphenethylamine (27) was dimethylated, and the $O$-methyl group of $\mathbf{2 8}$ was removed to yield phenol 29. Monomethyl phenol 32 (needed for compound 7) was prepared from 3methoxyphenethyl bromide (30, Scheme 2B) and methylamine, followed by demethylation of $\mathbf{3 1}$ and immediate Boc-protection (to aid in purification and prevent later interference by the free secondary amine). For the benzylic amine of 8, phenol 34 (Scheme 2C) was prepared by reductive amination of commercially available aldehyde 33 with $N, N$ dimethylamine. Similarly, exchanging $N, N$-dimethylamine for methylamine (needed for 9) yielded an amine, which was protected as $\mathbf{3 5}$. Phenol 37 (Scheme 2D) was prepared for the synthesis of $\mathbf{1 0}$ by Boc-protecting commercially available $\mathbf{3 6}$.

The longer linker of 13, via phenol 40, was prepared by a Sonogashira coupling of 3iodophenol $\mathbf{3 8}$ with $N, N$-dimethylpropargylamine, followed by reduction of the triple bond of 39 to yield 40 (Scheme 3A). For compound 14, 42 was prepared by a Mitsunobu reaction between resorcinol 41 and 3-(N,N-dimethylamino)ethanol ${ }^{32}$ (Scheme 3B). As performed for the meta-analogues, phenols 44 and 45 (for analogues 15 and 16, respectively, Scheme 4) were prepared from 4-hydroxybenzaldehyde (43) and either $N, N$-dimethylamine (for 44) or methylamine (for 45). 
The anilines required for $\mathbf{1 7}$ and $\mathbf{1 8}$ were prepared from 3-nitrobenzyl bromide (46, Scheme 5 ) upon treatment with either dimethylamine (47) or methylamine (followed by Bocprotection to yield 49). Reduction of the nitro group with Raney nickel afforded 48 (for 17) and $\mathbf{5 0}$ (for 18).

Finally, the substituted phenols (for 19-22, Scheme 6A) could be prepared by employing the reductive amination/Boc protection protocol to commercially available aldehydes $(\mathbf{5 1}, \mathbf{5 2})$ or acetophenone 53, to yield the protected amines 54-56, respectively. Lastly, the pyridinol $\mathbf{5 9}$ (for 21, Scheme 6B) was prepared by reductive amination of nicotinaldehyde 57 and cleavage of the methyl group of 58; Boc-protection furnished $\mathbf{5 9}$.

With the halves of the phenyl ether-substituted quinolines in hand, assembly of the final cores (Scheme 7) was completed by first treating the desired phenol $[\mathbf{2 9}, \mathbf{3 2}, \mathbf{3 4}, \mathbf{3 5}, \mathbf{3 7}, \mathbf{4 0}$, $42,44,45,54-56,59$, or commercially available 3-hydroxypyridine or 3-( $N, N$ dimethylamino)phenol (for compounds $\mathbf{1 1}$ and 12, respectively)] with sodium hydride in $\mathrm{DMF}$ at $0{ }^{\circ} \mathrm{C}$. A solution of $\mathbf{2 6}$ was then added; the reaction was typically complete within 1 h. Yields were good, but were lower for the tertiary amines because of partial solubility in the aqueous DMF solutions produced in the workup. The intermediate acetamides (60-74) were not characterized and were deprotected immediately after purification: the acetyl group was first removed by $\mathrm{K}_{2} \mathrm{CO}_{3}$ in refluxing methanol, and after isolation, the free aminoquinolines were treated with methanolic $\mathrm{HCl}$ in ether to produce water-soluble hydrochloride salts. Compounds without a Boc group were isolated after 5-15 min; those with a Boc group were stirred overnight for deprotection. In the case of 72, $\mathrm{HCl}$ induced unfavorable side-reactions, so TFA was used instead.

The microwave alkylation procedure of Romero et al. ${ }^{33}$ was employed to synthesize aniline 18 (Scheme 7). Compound 26, excess 50, and catalytic potassium iodide were heated in acetonitrile under microwave irradiation to furnish intermediate $\mathbf{7 5}$, which was deprotected as described above. Unfortunately, because of its nucleophilic amine, $\mathbf{4 8}$ only produced water-soluble quaternization products upon reaction with 26. It was proposed that the two halves of $N$-linked compound $\mathbf{1 7}$ could be joined via reductive amination, beginning with the quinolinecarboxaldehyde $\mathbf{8 1}$. After many unsuccessful attempts to prepare $\mathbf{8 1}$ from $\mathbf{2 5}$ and 26, 81 was prepared in five steps ${ }^{34}$ (Scheme 8), starting with a Wittig cyanovinylation of commercially available aldehyde 76; the desired trans-isomer $\mathbf{7 7}$ was obtained in good yield. Iron-catalyzed reductive cyclization yielded aminoquinoline $\mathbf{7 8}$, which was acetylated in good yield using $N$-acetylimidazole. Ester $\mathbf{7 9}$ was reduced to alcohol 80, and oxidation to $\mathbf{8 1}$ was performed using Dess-Martin periodinane. An indirect reductive amination with $\mathbf{4 8}$ was effective at elevated temperatures, and the crude acetamide was deprotected to yield $\mathbf{1 8 .}$

\section{Results and Discussion}

Compounds 6-22 were first assayed against purified rat nNOS, murine macrophage iNOS, and bovine eNOS using the hemoglobin capture assay. ${ }^{35,36}$ These species are used because (a) it is easiest to purify and readily obtain crystallographic data with these isozymes, and (b) there is a large active-site homology between mammalian species and therefore, while not $100 \%$ accurate, an adequate approximation of isoform selectivity can be obtained. Table 
1 summarizes the apparent $K_{\mathrm{i}}$ values and isoform selectivity values for $\mathbf{6 - 2 2}$; for the sake of comparison, values for $\mathbf{1}$ and $\mathbf{2}$ are included.

The first series of compounds, $\mathbf{6 - 1 2}$, is less potent than $\mathbf{1}$ or $\mathbf{2}$. At first glance, it appears compounds with a basic amino group (6-10) are more potent against nNOS than those with less basic groups such as pyridine (11) and $N, N$-dimethylaniline, which rendered compound 12 essentially inactive. The positioning of the tail amino group plays a role in enzymeinhibitor interactions. The crystal structures of nNOS-6 and nNOS-7 are compared side by side in Figure 4. The strong 2-aminoquinoline-Glu592 (arginine mimic) interaction characteristic of this class is well supported by the strong electron density. In contrast, the central aryl ring and the tail regions show rather weak density, indicative of disordering. The methylamine of 7 reaches the $\mathrm{H}_{4} \mathrm{~B}$ site because the tail is long enough to displace the water molecule normally present in this site, and $\mathrm{H}$-bond either with $\mathrm{H}_{4} \mathrm{~B}$ or with the nearby heme propionate (Figure 4B). This interaction pushes the central aryl ring into non-bonded contact with the Tyr706 side chain. However, the tertiary amino group of $\mathbf{6}$ does not interact with $\mathrm{H}_{4} \mathrm{~B}$ or heme, but hangs adjacent to Met336 because the central aryl ring presses against the heme propionate (Figure 4A). The lack of both the $\mathrm{H}_{4} \mathrm{~B}$ site and Tyr706 contacts likely explains why $\mathbf{6}$ is less potent than 7 .

When the tail is one methylene shorter, ( 8 and 9 vs. $\mathbf{6}$ and $\mathbf{7}$, respectively) the potency is also increased. As shown in Figure 5, the tertiary amino group of $\mathbf{8}$ can form an H-bond with Asn569, while the secondary amino group of $\mathbf{9}$ is involved in a water-mediated H-bonding network with $\mathrm{H}_{4} \mathrm{~B}$ and heme. The phenyl ring of 9 forms a pi-stacking interaction with Tyr706 (these rings are > $4 \AA$ apart in the nNOS-8 structure). These same interactions are observed in the nNOS-10 structure, which has a primary amino group, (see Supporting Information (SI) Figure S1).

Two trends are clear. First, potency is increased slightly upon removal of one methyl group from the tertiary amines; $\mathbf{9}$ and $\mathbf{1 0}$ are more potent than $\mathbf{8}$, and $\mathbf{7}$ is more potent than $\mathbf{6}$. The protonated secondary amino group bears two hydrogens and is a stronger H-bond donor than the tertiary amino group, as demonstrated by $\mathbf{7}$ and $\mathbf{9}$. Second, the longer chains of $\mathbf{6}$ and $\mathbf{7}$ show higher flexibility (structure disordering) in the phenyl ether and tail region when compared to $\mathbf{8}$ and $\mathbf{9}$, and thus could result in weaker or partial interactions as a result of entropy, leading to lower potency than $\mathbf{8}$ and $\mathbf{9}$. Interactions with Asn569 or the $\mathrm{H}_{4} \mathrm{~B}$ site are crucial for the activity of these compounds; the short amino group of $\mathbf{1 2}$ is incapable of forming these interactions, and this could be why $\mathbf{1 2}$ has little activity.

Interestingly, the n/e selectivity for $\mathbf{8}$ and $\mathbf{9}$ is similar to that observed for $\mathbf{1}$ or $\mathbf{2}$. It is known that contact between the halophenyl rings of $\mathbf{1}$ and $\mathbf{2}$ and the hydrophobic pocket residues Tyr706, Leu337, and Met336 improves potency and n/e selectivity. ${ }^{18}$ What is responsible for the $\mathrm{n} / \mathrm{e}$ selectivity for these compounds lacking obvious hydrophobic contact? X-ray crystallography indicates that in eNOS, a common binding mode is observed for most phenyl ether-linked aminoquinolines, characterized by an "upward" position of the ether bond, where the phenyl ring sits perpendicular to the plane of the aminoquinoline. In the eNOS-9 structure (Figure 6A), the perpendicular orientation of the phenyl ring breaks the $p i$ stacking interactions with Tyr706 (distance > $6 \AA$ ), and the phenyl ring and methylamine 
portion can be modeled in alternate conformations where the amine can either face toward or away from the $\mathrm{H}_{4} \mathrm{~B}$ site. Similar upward phenyl ring positions are also observed for $\mathbf{7}$ and 8 bound to eNOS (see SI Figure S2), indicating that this position occurs regardless of tail length or amine alkylation pattern.

While the perpendicular orientations found in these eNOS structures would diminish many of the interactions that confer binding to nNOS (and thus result in the observed n/e selectivity), it was unclear what structural difference between nNOS and eNOS resulted in these binding modes. Further complicating the interpretation of the eNOS structural data is the presence of both glycerol and acetate (crystallization buffer components) in all of the eNOS structures. While the glycerol is located peripheral relative to the inhibitor, the acetate (found in eNOS because of the alternate rotamer assumed by Arg252) abuts the perpendicular phenyl rings of the inhibitors and in several cases results in clearer electron density in the crystal structures, suggesting that the perpendicular binding modes may be stabilized by non-bonded contacts with the acetate, and are thus likely a crystallographic artifact. By removing acetate from the cryo-soaking buffer, we were able to confirm that acetate is, indeed, the reason for some of these inhibitors to adopt a different binding mode in eNOS. This will be considered in more detail when the structures of $\mathbf{2 0}$ bound to eNOS and nNOS are discussed below.

To confirm this hypothesis further, the rat nNOS double mutant D597N/M336V was employed, where Asp597 and Met336 are mutated to, respectively, the corresponding asparagine and valine found in bovine eNOS. This enzyme has previously been used as an eNOS "surrogate" to elucidate the effects that amino acid differences have on inhibitor binding. ${ }^{37,38}$ While the active-site sequence resembles eNOS, the overall local environment and domain architecture still resemble wild-type rat nNOS; Arg481 (the equivalent of Arg252) is retained in the WT nNOS rotameric state, and acetate no longer binds. In the nNOS-D597N/M336V-9-structure (Figure 6B) the phenyl ether portion of 9 reverts to the co-planar binding mode observed in WT rat nNOS, and not the perpendicular mode observed in the eNOS-9 structure, indicating the upward position of the phenyl ring is likely stabilized or induced by the acetate. Nonetheless, a difference in the positioning of the methylamine tail in the nNOS-D597N/M336V-9 structure (Figure 6B) could explain the observed selectivity for nNOS over eNOS. In the WT nNOS structure, the methylamine tail rotates away from bulky Met336, and the amino group faces toward the bridging water in the $\mathrm{H}_{4} \mathrm{~B}$ site (Figure 5B). In the double mutant structure, the smaller Val336 (analogous to eNOS' Val106) allows for the amine to instead face toward the hydrophobic pocket, breaking the $\mathrm{H}_{4} \mathrm{~B}$ site interaction. This is not the first reported case where subtle differences in Met/Val contacts have led to large effects on n/e selectivity ${ }^{18,39}$ and also serves as a cautionary note against over-reliance on X-ray structures in interpretation of SAR data. As no acetate is used in eNOS purification or assay, the observed eNOS selectivity for 9 was assumed to result from actual structural changes by comparing WT nNOS-9 and nNOSD597N/M336V-9 structures. Assaying 9 against nNOS-D597N/M336V yielded a $K_{\mathrm{i}}$ of 585 $\mathrm{nM}$. This value is four-fold higher than the WT nNOS $K_{\mathrm{i}}$, indicating that the Met-to-Val switch indeed disfavors binding to the double mutant. This value is also considerably lower than the eNOS $K_{\mathrm{i}}$ value $(25.3 \mu \mathrm{M})$, demonstrating that different amino acids are also not the 
full determinant of selectivity - subtle differences in sterics, electronics, or the local active site environment could also be responsible.

Although 6 and $\mathbf{7}$ are less potent than the shorter compounds $(\mathbf{8 - 1 0})$, we reasoned that elongation of the alkyl chain by one methylene unit (to phenylpropyl, such as in $\mathbf{1 3}$ and $\mathbf{1 4}$ ) might either force the $\mathrm{N}$-methyl groups toward the nNOS-specific hydrophobic pocket or place the basic amine near Asp597. Asn368 replaces Asp597 in eNOS (vide supra), and electrostatic or water-mediated contact with the latter residue has been previously implicated in high n/e selectivity. ${ }^{26,40}$ Disappointingly, this modification was ineffective: $\mathbf{1 3}$ and $\mathbf{1 4}$ are less potent than $\mathbf{6}$. Loss of activity upon extensive homologation was seen previously for 2 aminoquinoline compounds, ${ }^{18}$ hypothesized to result from sterically disfavored, suboptimal or partial interactions, or internal torsional strain.

We also synthesized para-substituted analogues $\mathbf{1 5}$ and $\mathbf{1 6}$ to investigate whether different ring substitution could improve potency or selectivity. Compound $\mathbf{1 5}$ has lower potency than meta-substituted analogue $\mathbf{9}\left(K_{\mathrm{i}} 283 \mathrm{nM}\right.$ vs. $\left.142 \mathrm{nM}\right)$, and desmethyl compound $\mathbf{1 6}$ is slightly less potent than $\mathbf{1 5}$, indicating that the binding mode of these compounds must be different from the meta-substituted analogues. The nNOS-15 crystal structure (Figure 7A) indicates that the phenyl ring of $\mathbf{1 5}$ is oriented quite differently from that of $\mathbf{9}$. The alkylamine tail of $\mathbf{1 5}$, as a para-substituent, extends out farther with high flexibility. The methyl group makes possible contact with Met336, but the amine loses its effective H-bond interaction with the $\mathrm{H}_{4} \mathrm{~B}$ site water. The flexible nature of the tail may allow it to make both the hydrophobic pocket and $\mathrm{H}_{4} \mathrm{~B}$ site contacts transiently.

We also employed the secondary aniline (17 and $\mathbf{1 8})$ as a bioisosteric replacement for the ether oxygen. Crystal structures of the phenyl ether-linked compounds indicated a possible placement for the $\mathrm{NH}$ group between the heme propionates, where it could make another electrostatic or H-bonding interaction. Surprisingly, the potency for $\mathbf{1 7}$ was lower than $\mathbf{8}$, and the loss of additional potency upon demethylation (to 18) indicated that $\mathbf{1 7}$ and $\mathbf{1 8}$ do not bind like $\mathbf{8}$ and $\mathbf{9}$. The nNOS-17 structure (Figure 7B) reveals instead that the aminoquinoline and central aryl rings sit $\sim 120^{\circ}$ relative to each other in a "butterfly" position, reflecting the geometry required for the aniline nitrogen to interact with the nearby heme propionate. As a result, the aryl ring moves upward, and the dimethylamine H-bonds to Asn569. It is not evident from this structure why $\mathbf{1 7}$ should be a worse nNOS inhibitor than $\mathbf{8}$ (or why demethylation should further attenuate the activity) but both steric crowding around the Asn569-dimethylamine area (highly disordered in the crystal structure) and the lack of the inhibitor-Tyr706 pi-stacking interaction observed in $\mathbf{8}$ and $\mathbf{9}$ could play a role. Additionally, the eNOS-17 structure (see SI Figure S3) reveals a nearly identical binding mode to that assumed in the nNOS-17 structure, which could be consistent with the low selectivity of $\mathbf{1 7}$.

While the addition of a fluorine or alpha-methyl group to 9 (to give $\mathbf{1 9}$ or 22, respectively) were neutral (19) or deleterious (22) modifications with regard to both potency and selectivity (relative to $\mathbf{9}$, and thus were not investigated further or examined crystallographically), the replacement of the phenyl ring of $\mathbf{9}$ with pyridyl (21) resulted in a substantial increase in potency ( $K_{\mathrm{i}} 142 \mathrm{nM}$ to $43 \mathrm{nM}$; more potent than 1 and 2). The 
nNOS-9 structure indicated the potential for the ring nitrogen to make an additional contact with Asn569, a prediction proven correct by the nNOS-21 structure (Figure 8A). Compound 21 assumes a well-defined, 9-like binding mode, where the external amine binds the $\mathrm{H}_{4} \mathrm{~B}$ site water and the pyridine ring simultaneously forms an edge-to-face pi-stacking interaction with Tyr706 and a polar contact with Asn569 (although at $3.7 \AA$, it is likely too far for a true H-bond). The high potency of $\mathbf{2 1}$ also highlights the absolute necessity of the external polar amine; compound 11, the unsubstituted 3-pyridine, binds nearly 17-fold weaker to nNOS than 21. While potent, 21 does not possess improved n/e selectivity relative to 9: this asparagine residue is conserved across all NOS isoforms and interaction with the pyridine likely non-specifically increases binding affinity to other isoforms, as manifested by the decreased $K_{\mathrm{i}}$ values for eNOS and iNOS as well.

In contrast to para-fluoro compound $\mathbf{1 9}$, the para-chloro analogue $\mathbf{2 0}$ is much more potent than compound $\mathbf{9}$, with high isoform selectivity comparable to $\mathbf{1}$ and $\mathbf{2}$. The nNOS-20 structure (Figure 8B) shows that the phenyl ring is flexible, having two possible orientations in the two nNOS monomers, where the amine can either displace the $\mathrm{H}_{4} \mathrm{~B}$-site water or point toward the hydrophobic pocket by rotation of the phenyl ring, while the chlorine can make Van der Waals contacts with Met336. The fluorine atom of $\mathbf{1 9}$ could be too small to make the latter contact, whereas the alpha-methyl group of $\mathbf{2 2}$ may be sterically disfavored in this region.

The eNOS-20 crystal structure (see SI Figure S4) also displays the "upward" binding mode and the stabilizing acetate ion. However, if acetate is removed from the cryo-soaking buffer, the phenyl ring of $\mathbf{2 0}$ no longer adopts the upward orientation (Figure 8C), but points toward the pocket bounded by Val106, Leu107, and Tyr477, similar to the binding mode observed in the rat nNOS double mutant D597N/M336-20 structure (Figure 8D). In addition, the positions of the phenyl ring and its two substituents (chlorine and methylamine) are better resolved than in the double mutant nNOS structure. The methylamine tail contacts Val106, but does not $\mathrm{H}$-bond with the $\mathrm{H}_{4} \mathrm{~B}$ or heme propionate $\mathrm{A}$ as observed in the wild type nNOS structure (Figure 8B). The chlorine makes no contact with Val106. As this binding mode is quite similar to that found in the double mutant structure (Figure 8D), we can confirm that acetate strongly influences the binding mode of inhibitors in eNOS structures and that the nNOS double mutant is indeed a good mimic of eNOS. In the nNOS double mutant-20 structure (Figure 8D) the Met-to-Val switch causes a significant change in binding mode: the phenyl ring has a single orientation rather than the two different ones observed in WT nNOS. The amine- $\mathrm{H}_{4} \mathrm{~B}$ site interaction is broken; instead, the methylamine tail fits in the hydrophobic pocket, larger because of the smaller Val336 residue. In addition, there is a lack of van der Waals contact between 20's chlorine atom and Val336. Assaying 20 against nNOS D597N/M336V gave a $K_{\mathrm{i}}$ value $(863 \mathrm{nM})$ that is in between that of the WT nNOS $(58 \mathrm{nM})$ and eNOS $(12.5 \mu \mathrm{M}) K_{\mathrm{i}}$ values, indicating, like for $\mathbf{9}$, that differences in amino acid sequence (such as Met to Val) do not fully account for the observed selectivity. Nonetheless, the double-mutant nNOS/wild-type nNOS selectivity ratio (15) is higher than 9's (4) showing, as the crystal structure does, that the inhibitor-Met336 contact plays a greater role in $\mathrm{n} / \mathrm{e}$ selectivity for $\mathbf{2 0}$ than it does for $\mathbf{9}$. 
In addition to the good n/e selectivity, the majority of the phenyl ether compounds are also poor iNOS inhibitors $(20-150 \mu \mathrm{M})$. We had previously reported this incompatibility between iNOS and 2-aminoquinolines. ${ }^{17}$ The high $\mathrm{n} / \mathrm{i}$ selectivity was attributed in part to the mismatch between the smaller and more rigid heme-binding pocket of iNOS ${ }^{41}$ and the bulky aminoquinoline, and in part to hydrophobic pocket contacts (as murine iNOS contains a polar residue, Asn115, in place of Leu337 of rat nNOS). Indeed, a bulky and hydrophobic group, such as chlorophenyl, may clash in the region of Asn115 and possibly lead to the high $\mathrm{n} / \mathrm{i}$ selectivity observed for $\mathbf{2 1}$.

Several compounds of interest $(\mathbf{6}, \mathbf{8}, \mathbf{9}, \mathbf{1 5}, \mathbf{1 7}, \mathbf{2 0}$, and $\mathbf{2 1})$ were also assayed against purified human nNOS (Table 2). The human nNOS active site differs from rat nNOS by one residue - Leu337 is replaced by His $342 .{ }^{42,43}$ The peripheral pocket of human nNOS, therefore, prefers binding smaller and more hydrophilic fragments, as evident from the high rat nNOS/ human nNOS selectivity for the hydrophobic-tailed compounds $\mathbf{1}$ and $\mathbf{2}$. If the bound inhibitor cannot reach the Leu/His site, an identical binding mode should be found in both rat and human nNOS structures. ${ }^{42}$ Aniline $\mathbf{1 7}$ is a typical example. In the human nNOS-17 structure (see SI Figure S5), the "butterfly" binding mode is identical to that found in the rat nNOS-17 structure, and the bound inhibitor is far from the Leu/His site. Therefore, there should be little selectivity ( $\mathrm{r} / \mathrm{h}=1.8$ only) between these two nNOS enzymes. Most of the ether-linked compounds are poor human nNOS inhibitors $\left(K_{\mathrm{i}}=1-2 \mu \mathrm{M}\right)$. The most potent human nNOS inhibitor, 20, is still selective for rat nNOS over human nNOS, even though it is approximately as potent as $\mathbf{1}$. The human nNOS-20 structure (Figure 9A) shows a consistent phenyl ring orientation where the dimethylamine makes an $\mathrm{H}$-bond with the $\mathrm{H}_{4} \mathrm{~B}$ site water; whereas in the rat nNOS-20 structure (Figure 8B) the phenyl ring rotates and allows the dimethylamine to displace the $\mathrm{H}_{4} \mathrm{~B}$ site water molecule in one orientation, but extends the amine to the hydrophobic pocket in the other orientation (not shown). Apparently, the bulkier His342 in human nNOS influences the phenyl position of $\mathbf{2 0}$ differently than Leu337 in rat nNOS.

Pyridine analogue 21 strongly prefers to bind to rat nNOS $(\mathrm{r} / \mathrm{h}=11.8)$, although the binding mode shows almost no difference in the two nNOS structures (Figure 9B for human). The only subtle difference observed in the structures is the side chain orientation of Tyr706 in rat compared to Tyr711 in human nNOS (because of the closer contacts from His342 in the human enzyme). A slight change in the edge-to-face $p i$-stacking interaction between the tyrosine and the inhibitor's pyridyl ring, however, would likely not fully account for the great difference in inhibitory potency.

Encouraged by the potency and selectivity of $\mathbf{2 0}$, this compound was tested in a Caco-2 assay (Table 3), in which a compound's ability to cross a monolayer of cells (resembling the intestinal lumen) is measured. This assay can be used to approximate permeability of the gut epithelium, and, to a lesser extent, the blood-brain barrier. ${ }^{44,45}$ Compound $\mathbf{1}$, an orally bioavailable, brain-penetrant nNOS inhibitor, has good membrane permeability in the apical to basolateral $\left(\mathrm{A} \rightarrow \mathrm{B}\right.$ ) direction (a mean $\mathrm{P}_{\mathrm{app}}$ of $16.9 \times 10^{-6} \mathrm{~cm} \mathrm{~s}^{-1}$ ), high compound recovery values, and a low efflux ratio [ratio of membrane permeability $(\mathrm{A} \rightarrow \mathrm{B})$ to efflux $(\mathrm{B} \rightarrow \mathrm{A}),<3$ is considered favorable]. Unfortunately, compound 20 is less cell-penetrant, has a slightly higher efflux ratio than $\mathbf{1}$, and has a lower $\mathrm{A} \rightarrow \mathrm{B}$ recovery value, potentially 
indicative of poor solubility or metabolic lability in these cells. Nonetheless, although suboptimal, some permeability is retained despite the drastic structural rearrangement.

Finally, 20 was screened by the PDSP. ${ }^{19}$ In this assay, compounds are assayed against a panel of 45 pharmacologically relevant CNS targets via radioligand binding assays. We have classified off-target binding (Table 4) into four categories: concerning $\left(K_{\mathrm{i}}<100 \mathrm{nM}\right.$, or < $\sim 2 \times \operatorname{nNOS} K_{\mathrm{i}}$ value), moderate (100-300 nM, $\sim 2-5 \times \mathrm{nNOS} K_{\mathrm{i}}$ value), weak (> $300 \mathrm{nM}$, or $>\sim 5 \times \mathrm{nNOS} K_{\mathrm{i}}$ value, typically $\left.\sim 1 \mu \mathrm{M}\right)$, and insignificant $(<50 \%$ at $10 \mu \mathrm{M})$. For compound 2 , a promiscuous scaffold with low therapeutic index, binding was considered concerning or moderate at 15/45 targets (mostly serotonin and histamine receptors), with 22/45 targets classified as weak, and 8/45 as insignificant. For compound 20, the concerning/moderate binding fraction has decreased to 6 targets, and the insignificant binding fraction has increased considerably, from $8 / 45$ to $22 / 45$, with the majority of the decrease coming from serotonin receptors. These results indicate that truncation and structural rearrangement, as observed for $\mathbf{4}$ and $\mathbf{5}$, are effective at reducing off-target CNS binding and could potentially translate to improved safety in vivo, making the phenyl ether-linked core an exciting scaffold for further optimization.

\section{Conclusions}

To summarize, we have developed a novel series of 2-aminoquinoline-based nNOS inhibitors, using the rationale that this particular "rearranged" scaffold could maintain or enhance the potency and isoform selectivity of our previous leads ( $\mathbf{1}$ and $\mathbf{2}$ ) while diminishing the off-target binding of these compounds. Assaying this new generation of inhibitors (containing an exterior polar amine and an interior hydrophobic portion linked to the aminoquinoline via a phenyl ether or aniline) against purified NOS enzymes indicated that $\mathbf{9}$, while having lower potency than $\mathbf{1}$ or $\mathbf{2}$, maintained the triple-digit isoform selectivity of the leads. X-ray crystallography (using rat nNOS and a rat nNOS double mutant) indicated that the n/e selectivity might arise from enhanced hydrophobic contacts between the tail of the inhibitor and the nNOS-specific hydrophobic pocket. Elongating the chain between the aryl ring and the amine, changing the ring substitution pattern, and replacing the phenyl ether linkage with an aniline failed to improve 9's potency and selectivity, but one compound (20), chlorinated on the central aryl ring, was found to be a potent and selective inhibitor of both rat and human nNOS. Although lower than compound 1, 20 still displayed some cellular permeability in a Caco-2 assay despite the significant structural rearrangement. Most promisingly, when assayed against a panel of 45 relevant CNS targets and receptors in the PDSP, 20 showed diminished off-target interactions relative to $\mathbf{2}$ (a promiscuous binder) indicating that potent and selective compounds based on the inverted phenyl ether core may have the potential for improved safety in vivo.

\section{Experimental Section}

\section{General Procedures}

Anhydrous solvents (THF, $\mathrm{CH}_{2} \mathrm{Cl}_{2}, \mathrm{MeOH}$, and DMF) were distilled prior to use. The remaining solvents, reactants, and reagents were purchased from commercial vendors and were used without further purification. Methanolic $\mathrm{HCl}$ (3 M, for ammonium salt formation 
and Boc-deprotection) was prepared fresh by the reaction of acetyl chloride and anhydrous $\mathrm{MeOH}$ at $0{ }^{\circ} \mathrm{C}$. Melting points were determined in capillary tubes using a Buchi melting point B-540 apparatus and are uncorrected. ${ }^{1} \mathrm{H}-\mathrm{NMR}$ spectra were recorded at $500 \mathrm{MHz}$, using a Bruker Avance III 500 (direct cryoprobe), and ${ }^{13} \mathrm{C}-\mathrm{NMR}$ spectra were obtained at $126 \mathrm{MHz}$ using the same instrument. Low-resolution ESIMS was performed using a Bruker AmaZon SL Ion Trap mass spectrometer system. High-resolution mass spectral data were obtained at the Integrated Molecular Structure Education and Research Center (Northwestern University) on an Agilent 6210A TOF mass spectrometer in positive ion mode using electrospray ionization with an Agilent G1312A HPLC pump and an Agilent G1367B autoinjector. Data were processed using MassHunter software version B.04.00. Flash column chromatography was performed using an Agilent 971-FP automated flash purification system with a Varian column station and SiliCycle cartridges (12-80 g). Analytical HPLC was performed using an Agilent Infinity 1260 HPLC system and injection volumes of 5-10 $\mu \mathrm{L}$. A Phenomenex Luna $5 \mu \mathrm{m}$ C-8(2) $100 \AA$ column, $50 \times 4.60 \mathrm{~mm}$, was used for all HPLC experiments, using a 10-minute gradient of $95 \% \mathrm{H}_{2} \mathrm{O} / 5 \%$ acetonitrile + $0.05 \%$ TFA to $95 \%$ acetonitrile $/ 5 \% \mathrm{H}_{2} \mathrm{O}+0.05 \% \mathrm{TFA}$, at $1.5 \mathrm{~mL} / \mathrm{min}$. The purity of all final target compounds was found to be $₫ 5 \%$ by HPLC. Preparative HPLC was performed at the Northwestern University Center for Molecular Innovation and Drug Discovery ChemCore lab, using an Agilent 1200 Series HPLC and Agilent 6120 Quadrupole Mass Spectrometer (API-MS mode) and $150 \times 21.2 \mathrm{~mm}$ preparative HPLC columns (described under subheadings for individual compounds). Microwave chemistry was performed using a Biotage Initiator Sixty research microwave in Biotage vials. Analytical thin-layer chromatography was performed on Silicycle extra hard $250 \mu \mathrm{m}$ TLC plates. Compounds were visualized with short-wavelength UV light, and with ninhydrin, $\mathrm{FeCl}_{3}$, and $\mathrm{KMnO}_{4}$ stain, where relevant. Compounds $\mathbf{2 3},{ }^{18} \mathbf{2 6},{ }^{31,46} \mathbf{3 1},{ }^{47} \mathbf{3 7},{ }^{48}$ and $\mathbf{4 2}^{32}$ were prepared by known literature procedures, and their spectral data are consistent with those data reported for them. The preparation of phenols, anilines, and precursors 28-59 and is discussed in the Supplemental Information.

\section{2-Amino-7-methylquinoline (24)}

Compound 23 (1.00 g, $5.63 \mathrm{mmol}$ ), DavePhos (0.051 g, $2 \mathrm{~mol} \%)$, and $\operatorname{Pd}_{2}(\mathrm{dba})_{3}(0.051 \mathrm{~g}$, $\sim 1 \mathrm{~mol} \%$ ) in a sealed tube or Biotage $20 \mathrm{~mL}$ microwave vial were diluted with anhydrous dioxane (6 mL), and LHMDS ( $1 \mathrm{M}$ in THF, $12 \mathrm{~mL}, 12 \mathrm{mmol}$ ) was added slowly. The solution was purged with argon for $5 \mathrm{~min}$, sealed, and heated to $100{ }^{\circ} \mathrm{C}$ for $20 \mathrm{~h}$. The mixture was cooled and poured into aqueous $\mathrm{HCl}(1 \mathrm{M}, 20 \mathrm{~mL})$ and stirred for $10 \mathrm{~min}$ before EtOAc $(20 \mathrm{~mL})$ was added. The layers were separated and the aqueous layer was extracted with $1 \mathrm{M} \mathrm{HCl}(3 \times 50 \mathrm{~mL})$; the aqueous phase was washed repeatedly with EtOAc $(3 \times 30 \mathrm{~mL})$ and the combined organic phase was discarded. The aqueous phase was basified to $\mathrm{pH} 9$ with $\mathrm{NaOH}$ and extracted with EtOAc $(2 \times 150 \mathrm{~mL})$. The organic phase was washed with sat. aq. $\mathrm{NaCl}(100 \mathrm{~mL})$, dried, and concentrated to yield the crude aminoquinoline as an off-white iridescent solid $(0.900 \mathrm{~g}, 100 \%$ with minor impurities); analytical data for this compound are as previously described. ${ }^{29}$ 


\section{2-(Acetamido)-7-methylquinoline (25)}

Compound 24 (3.02 g, $19.1 \mathrm{mmol})$ was diluted with anhydrous THF (100 mL), $N$ acetylimidazole $(2.52 \mathrm{~g}, 23.0 \mathrm{mmol})$ was added, and the mixture was heated at reflux for 17 h. The mixture was cooled, concentrated, and the residue was diluted with EtOAc $(200 \mathrm{~mL})$ and washed with $\mathrm{H}_{2} \mathrm{O}(\sim 500 \mathrm{~mL})$ and sat. aq. $\mathrm{NaCl}(100 \mathrm{~mL})$. The organic layer was dried over anhydrous sodium sulfate and concentrated. The residue was dissolved in a minimal amount of hot EtOAc and precipitated with hexanes $(\sim 200 \mathrm{~mL})$ to yield 25 as a pale-tan iridescent solid (3.23 g, 85\%) after washing with hexanes. Analytical data for this compound are consistent with those previously reported. ${ }^{18,29}$

\section{General Procedure for Synthesis and Deprotection of Phenyl Ether-Linked Aminoquinolines}

Sodium hydride (60\% suspension in mineral oil, 1 eq.) was diluted with anhydrous DMF (1$2 \mathrm{~mL}$ ) and cooled to $0{ }^{\circ} \mathrm{C}$ under argon. A solution of the required phenol (1 eq.) in anhydrous DMF (1-2 mL) was added slowly to the suspension and stirred at $0{ }^{\circ} \mathrm{C}$ for $10-30$ min (typically $\sim 25 \mathrm{~min}$ ), following which bromide $\mathbf{2 6}$ ( 1 eq.) was added as a solution in anhydrous DMF. The reaction mixture was stirred at $0{ }^{\circ} \mathrm{C}$ for $40 \mathrm{~min}-1 \mathrm{~h}$ (typically $\sim 50$ min), and quenched at $0{ }^{\circ} \mathrm{C}$ by addition of a $1: 1$ sat. aq. $\mathrm{NaCl} / \mathrm{H}_{2} \mathrm{O}$ mixture $(\sim 15 \mathrm{~mL})$ or a sat. aq. $\mathrm{NaHCO}_{3}$ solution. The mixture was extracted with EtOAc (usually $3 \times 20 \mathrm{~mL}$ was sufficient; for tertiary amines, more exhaustive extraction was required) and the organic phase was washed with $5 \%$ aq. $\mathrm{NaCl}(3-4 \times 30-80 \mathrm{~mL})$ and sat aq. $\mathrm{NaCl}(30-50 \mathrm{~mL})$. The organic layer was dried over anhydrous sodium sulfate, concentrated, and purified by flash column chromatography (12 $\mathrm{g} \mathrm{SiO}_{2}$ cartridge), using gradients as described for individual compounds below. The resulting intermediate acetamides were not characterized or purified further, but were diluted with anhydrous $\mathrm{MeOH}(5-10 \mathrm{~mL})$, and anhydrous $\mathrm{K}_{2} \mathrm{CO}_{3}(2-2.5$ eq.) was added. The mixture was heated at reflux for $2-2.5$, cooled, and concentrated. The resulting residue was partitioned between EtOAc and 1:1 $\mathrm{H}_{2} \mathrm{O} /$ sat. aq. $\mathrm{NaCl}$, and the aqueous layer was extracted with EtOAc $(2-3 \times 5-20 \mathrm{~mL})$. The organic layers were washed with sat. aq. $\mathrm{NaCl}$ and dried over anhydrous sodium sulfate. Purification is detailed under subheadings for individual compounds. The free aminoquinoline was diluted in dry ether (or 10:1 ether $(\mathrm{MeOH})$ and filtered to remove any particulate matter. To the filtered solution, methanolic $\mathrm{HCl}(3 \mathrm{M}, 1.5 \mathrm{~mL}$ ) was added, and the mixture was stirred either $5 \mathrm{~min}$ (when a Boc group was not present) or overnight (when a Boc group was present). The hydrochloride salts were isolated by filtration, and the final purification was performed as described below for individual compounds.

\section{7-[(3-(2-(Dimethylamino)ethyl)phenoxy)methyl]quinolin-2-amine Dihydrochloride (6)}

This was prepared from $26(0.150 \mathrm{~g}, 0.54 \mathrm{mmol})$ and phenol $29(0.089 \mathrm{~g}, 0.54 \mathrm{mmol})$. Workup and purification by flash column chromatography, eluting with a gradient of $2 \%$ $\mathrm{MeOH}$ in EtOAc to 30\% $\mathrm{MeOH}$ in EtOAc, afforded the intermediate acetamide $\mathbf{6 0}$ as a white semisolid $(0.081 \mathrm{~g}, 41 \%)$, that was immediately deprotected using $\mathrm{K}_{2} \mathrm{CO}_{3}(0.062 \mathrm{~g}$, $0.446 \mathrm{mmol}$ ). After workup, the resulting gum was dissolved in minimal EtOAc, and hexanes were added to precipitate a white solid. This procedure was repeated twice, and the solid was diluted with $10 \% \mathrm{MeOH}$ in ether $(10 \mathrm{~mL})$, filtered, and concentrated. The 
resulting residue was diluted in ether $(\sim 10 \mathrm{~mL})$ and treated with methanolic $\mathrm{HCl}$ for $5 \mathrm{~min}$. Filtration afforded $\mathbf{6}(0.050 \mathrm{~g}, 57 \%$ from $\mathbf{6 4})$ as a cream-colored powder after washing with ether $\left(3 \times 2 \mathrm{~mL}\right.$ ): $\mathrm{mp} 115-120{ }^{\circ} \mathrm{C}$ (softens), $240{ }^{\circ} \mathrm{C}(\mathrm{dec}) .{ }^{1} \mathrm{H}-\mathrm{NMR}\left(500 \mathrm{MHz}\right.$; DMSO- $d_{6}: \delta$ 14.37 (s, $1 \mathrm{H}), 10.46$ (s, $1 \mathrm{H}), 9.21$ (br s, $1 \mathrm{H}), 8.38$ (d, $J=9.3 \mathrm{~Hz}, 1 \mathrm{H}), 8.22(\mathrm{br} \mathrm{s}, 1 \mathrm{H})$, $7.95(\mathrm{~d}, J=8.2 \mathrm{~Hz}, 1 \mathrm{H}), 7.78(\mathrm{~s}, 1 \mathrm{H}), 7.54(\mathrm{dd}, J=8.2,1.4 \mathrm{~Hz}, 1 \mathrm{H}), 7.28(\mathrm{t}, J=7.9 \mathrm{~Hz}, 1$ H), $7.11(\mathrm{~d}, J=9.3 \mathrm{~Hz}, 1 \mathrm{H}), 7.02(\mathrm{~d}, J=1.7 \mathrm{~Hz}, 1 \mathrm{H}), 6.95(\mathrm{dd}, J=8.0,2.3 \mathrm{~Hz}, 1 \mathrm{H}), 6.89$ $(\mathrm{d}, J=7.6 \mathrm{~Hz}, 1 \mathrm{H}), 5.32$ (s, $2 \mathrm{H}), 3.29$ (dt, $J=12.1,4.6 \mathrm{~Hz}, 2 \mathrm{H}), 3.01-2.98(\mathrm{~m}, 2 \mathrm{H}), 2.80$ (s, $3 \mathrm{H}), 2.79$ (s, $3 \mathrm{H}) ;{ }^{13} \mathrm{C}-\mathrm{NMR}\left(126 \mathrm{MHz}\right.$; DMSO- $\left.d_{6}\right)$ : $\delta 158.2,154.4,142.8,142.3$, 138.6, 135.8, 129.8, 129.0, 123.8, 121.5, 120.3, 115.5, 115.1, 113.7, 113.0, 68.4, 57.1, 42.1, 29.8; ESIMS m/z (rel. intensity) $322\left(\mathrm{MH}^{+}, 100\right)$; HRMS calcd for $\mathrm{C}_{20} \mathrm{H}_{24} \mathrm{~N}_{3} \mathrm{O}$ : 322.1919; found: 322.1912 .

\section{7-[(3-(2-(Methylamino)ethyl)phenoxy)methyl]quinolin-2-amine Dihydrochloride (7)}

This was prepared from $26(0.150 \mathrm{~g}, 0.54 \mathrm{mmol})$ and phenol $32(0.138 \mathrm{~g}, 0.54 \mathrm{mmol})$. Workup and purification by flash column chromatography, eluting with a gradient of $5 \%$ EtOAc in $\mathrm{CH}_{2} \mathrm{Cl}_{2}$ to $40 \%$ EtOAc in $\mathrm{CH}_{2} \mathrm{Cl}_{2}$, afforded intermediate acetamide $\mathbf{6 1}$ as a white semisolid (0.181 g, 74\%), which was immediately deprotected using $\mathrm{K}_{2} \mathrm{CO}_{3}(0.111 \mathrm{~g}, 0.806$ $\mathrm{mmol})$. After workup, the resulting gum was triturated with hexanes and 1:1 ether/hexanes (5 mL each) and filtered to yield a white solid that was suspended in ether $(8 \mathrm{~mL})$ and treated with methanolic $\mathrm{HCl}(1.5 \mathrm{~mL})$ for $20 \mathrm{~h}$. Filtration afforded $7(0.105 \mathrm{~g}, 69 \%$ from 61) as a chalky white solid after trituration with $10 \% \mathrm{MeOH}$ in ether $(3 \times 1 \mathrm{~mL})$ : $\mathrm{mp} 211.5-213$ ${ }^{\circ} \mathrm{C} .{ }^{1} \mathrm{H}-\mathrm{NMR}\left(500 \mathrm{MHz}\right.$; DMSO- $d_{6}$ ): $\delta 14.48$ (s, $\left.1 \mathrm{H}\right), 9.26$ (br s, $\left.1 \mathrm{H}\right), 9.01(\mathrm{~s}, 2 \mathrm{H}), 8.37$ (d, $J=9.3 \mathrm{~Hz}, 1 \mathrm{H}), 8.27(\mathrm{br} \mathrm{s}, 1 \mathrm{H}), 7.95(\mathrm{~d}, J=8.2 \mathrm{~Hz}, 1 \mathrm{H}), 7.78(\mathrm{~s}, 1 \mathrm{H}), 7.54(\mathrm{dd}, J=8.2$, $1.0 \mathrm{~Hz}, 1 \mathrm{H}), 7.27(\mathrm{t}, J=7.9 \mathrm{~Hz}, 1 \mathrm{H}), 7.12(\mathrm{~d}, J=9.3 \mathrm{~Hz}, 1 \mathrm{H}), 6.99(\mathrm{~s}, 1 \mathrm{H}), 6.94$ (dd, $J=$ 8.2, $2.4 \mathrm{~Hz}, 1 \mathrm{H}), 6.87(\mathrm{~d}, J=7.6 \mathrm{~Hz}, 1 \mathrm{H}), 5.32(\mathrm{~s}, 2 \mathrm{H}), 3.16-3.11(\mathrm{~m}, 2 \mathrm{H}), 2.93(\mathrm{t}, J=8.0$ $\mathrm{Hz}, 2 \mathrm{H}), 2.55(\mathrm{t}, J=5.4 \mathrm{~Hz}, 3 \mathrm{H}) .{ }^{13} \mathrm{C}-\mathrm{NMR}\left(126 \mathrm{MHz}\right.$; DMSO- $\left.d_{6}\right): \delta 158.2,154.4,142.8$, $142.3,138.9,135.8,129.8,129.0,123.8,121.4,120.3,115.4,115.1,113.7,113.0,68.4$, 48.9, 32.3, 31.4; ESIMS $m / z$ (rel. intensity) $308\left(\mathrm{MH}^{+}, 100\right)$; HRMS calcd for $\mathrm{C}_{19} \mathrm{H}_{22} \mathrm{~N}_{3} \mathrm{O}$ : 308.1763; found: 308.1760 .

\section{7-[(3-(Dimethylamino)methyl)phenoxy)methyl]quinolin-2-amine Dihydrochloride (8)}

This was prepared from $26(0.120 \mathrm{~g}, 0.42 \mathrm{mmol})$ and phenol $34(0.065 \mathrm{~g}, 0.43 \mathrm{mmol})$. Workup and purification by flash column chromatography, eluting with a gradient of $2 \%$ $\mathrm{MeOH}$ in EtOAc to 30\% $\mathrm{MeOH}$ in EtOAc, afforded intermediate acetamide 62 as a white gum (0.091 g, 61\%), which was deprotected using $\mathrm{K}_{2} \mathrm{CO}_{3}(0.089 \mathrm{~g}, 0.65 \mathrm{mmol})$. After workup, the resulting syrup was triturated with 5:1 DCM: hexanes $(5 \mathrm{~mL})$ to yield a white solid. This was diluted in EtOAc (3 mL), filtered to remove particulates, and concentrated. The residue was diluted in $\mathrm{MeOH}(1 \mathrm{~mL})$ and treated with methanolic $\mathrm{HCl}(1.5 \mathrm{~mL})$. Ether was added to precipitate a gum that was washed with $5 \% \mathrm{MeOH}$ in ether and ether $(1 \mathrm{~mL}$ each) to yield $8\left(0.063 \mathrm{~g}, 64 \%\right.$ from 62) as a pale-yellow foam: mp $76{ }^{\circ} \mathrm{C}$ (softens), $91-94$ ${ }^{\circ} \mathrm{C}$ (melts), $240{ }^{\circ} \mathrm{C}(\mathrm{dec}) .{ }^{1} \mathrm{H}-\mathrm{NMR}\left(500 \mathrm{MHz}\right.$; DMSO- $\left.d_{6}\right): \delta 14.37$ (s, $\left.1 \mathrm{H}\right), 10.77$ (s, $1 \mathrm{H}$ ), $9.21(\mathrm{br} \mathrm{s}, 1 \mathrm{H}), 8.38(\mathrm{~d}, J=9.3 \mathrm{~Hz}, 1 \mathrm{H}), 8.24(\mathrm{~s}, 1 \mathrm{H}), 7.95(\mathrm{~d}, J=8.2 \mathrm{~Hz}, 1 \mathrm{H}), 7.78(\mathrm{~s}, 1$ H), $7.55(\mathrm{dd}, J=8.2,1.4 \mathrm{~Hz}, 1 \mathrm{H}), 7.41-7.38(\mathrm{~m}, 2 \mathrm{H}), 7.15-7.10(\mathrm{~m}, 3 \mathrm{H}), 5.36(\mathrm{~s}, 2 \mathrm{H})$, $4.24(\mathrm{~d}, J=5.3 \mathrm{~Hz}, 2 \mathrm{H}), 2.68$ (s, $3 \mathrm{H}), 2.67$ (s, $3 \mathrm{H}) .{ }^{13} \mathrm{C}-\mathrm{NMR}\left(126 \mathrm{MHz}\right.$; DMSO- $\left.d_{6}\right): \delta$ 
158.2, 154.4, 142.9, 142.1, 132.1, 130.1, 129.1, 124.0, 123.6, 120.4, 117.5, 115.9, 115.2, 113.9, 68.6, 59.4, 48.7, 41.6; ESIMS $\mathrm{m} / z$ (rel. intensity) $308\left(\mathrm{MH}^{+}, 100\right)$; HRMS calcd for $\mathrm{C}_{19} \mathrm{H}_{22} \mathrm{~N}_{3} \mathrm{O}: 308.1763$; found: 308.1757 .

\section{7-[(3-(Methylamino)methyl)phenoxy)methyl]quinolin-2-amine Dihydrochloride (9)}

This was prepared from $26(0.150 \mathrm{~g}, 0.54 \mathrm{mmol})$ and phenol 35 ( $0.128 \mathrm{~g}, 0.54 \mathrm{mmol})$. Workup and purification by flash column chromatography, eluting with 5\% EtOAc in $\mathrm{CH}_{2} \mathrm{Cl}_{2}$ to $33 \%$ EtOAc in $\mathrm{CH}_{2} \mathrm{Cl}_{2}$, afforded intermediate acetamide $\mathbf{6 3}$ as a colorless foam $(0.184 \mathrm{~g}, 78 \%)$, which was deprotected using $\mathrm{K}_{2} \mathrm{CO}_{3}(0.117 \mathrm{~g}, 0.844 \mathrm{mmol})$. After workup, the resulting residue was diluted in ether $(5 \mathrm{~mL})$, filtered to remove particulates, and treated with methanolic $\mathrm{HCl}(1.5 \mathrm{~mL})$ for $20 \mathrm{~h}$. Ether $(3 \mathrm{~mL})$ was added, and the precipitate was filtered to yield 9 as a white amorphous solid $(0.102 \mathrm{~g}, 66 \%$ from 63$)$ after trituration with 2:1 ether/MeOH $(2 \mathrm{~mL})$ and washing with ether $(2 \mathrm{~mL})$ : $\mathrm{mp} 257-259{ }^{\circ} \mathrm{C} .{ }^{1} \mathrm{H}-\mathrm{NMR}(500$ MHz; DMSO- $d_{6}$ ): $\delta 14.41$ (s, $\left.1 \mathrm{H}\right), 9.27$ (s, $\left.3 \mathrm{H}\right), 8.37$ (d, $\left.J=9.3 \mathrm{~Hz}, 1 \mathrm{H}\right), 8.30$ (br s, $\left.1 \mathrm{H}\right)$, $7.95(\mathrm{~d}, J=8.2 \mathrm{~Hz}, 1 \mathrm{H}), 7.78(\mathrm{~s}, 1 \mathrm{H}), 7.55-7.53(\mathrm{~m}, 1 \mathrm{H}), 7.37(\mathrm{t}, J=7.9 \mathrm{~Hz}, 1 \mathrm{H}), 7.33(\mathrm{~s}$, $1 \mathrm{H}), 7.12-7.08(\mathrm{~m}, 3 \mathrm{H}), 5.35(\mathrm{~s}, 2 \mathrm{H}), 4.08(\mathrm{t}, J=5.5 \mathrm{~Hz}, 2 \mathrm{H}), 2.52(\mathrm{~d}, J=5.2 \mathrm{~Hz}, 3 \mathrm{H}$, partially obscured by solvent signal); ${ }^{13} \mathrm{C}-\mathrm{NMR}\left(126 \mathrm{MHz}\right.$; DMSO- $\left.d_{6}\right): \delta 158.1,154.4$, 142.8, 142.1, 135.8, 133.6, 129.9, 129.0, 123.8, 122.5, 120.3, 116.6, 115.14, 115.10, 113.8, 68.5, 51.0, 31.9; ESIMS $m / z$ (rel. intensity) $294\left(\mathrm{MH}^{+}, 100\right)$; HRMS calcd for $\mathrm{C}_{18} \mathrm{H}_{20} \mathrm{~N}_{3} \mathrm{O}$ : 294.1606; found: 294.1603 .

\section{7-[(3-Aminomethyl)phenoxy)methyl]quinolin-2-amine Dihydrochloride (10)}

This was prepared from $26(0.100 \mathrm{~g}, 0.358 \mathrm{mmol})$ and phenol $37(0.080 \mathrm{~g}, 0.358 \mathrm{mmol})$. Workup and purification by flash column chromatography, eluting with 5\% EtOAc in $\mathrm{CH}_{2} \mathrm{Cl}_{2}$ to $50 \%$ EtOAc in $\mathrm{CH}_{2} \mathrm{Cl}_{2}$, afforded intermediate acetamide $\mathbf{6 4}$ as a colorless foam $(0.121 \mathrm{~g}, 80 \%)$, which was deprotected using $\mathrm{K}_{2} \mathrm{CO}_{3}(0.079 \mathrm{~g}, 0.569 \mathrm{mmol})$. After workup, the resulting gum was triturated with 5:1 ether/hexanes and 2:1 hexanes/EtOAc (5 mL each) to yield the product as a white solid, which was diluted in $\mathrm{MeOH}$, filtered to remove particulates, and concentrated. The residue was diluted with ether $(8 \mathrm{~mL})$ and treated with methanolic $\mathrm{HCl}(1.5 \mathrm{~mL})$ for $20 \mathrm{~h}$. The precipitate was filtered to yield $\mathbf{1 0}$ as a white powder $(0.050 \mathrm{~g}, 50 \%$ from 64) after trituration with $15 \% \mathrm{MeOH}$ in ether $(2 \times 2 \mathrm{~mL})$ and $2: 1$ ether/ $\mathrm{MeOH}(2 \mathrm{~mL})$ and washing with ether $(2 \mathrm{~mL})$ : mp $254-255^{\circ} \mathrm{C} .{ }^{1} \mathrm{H}-\mathrm{NMR}(500 \mathrm{MHz}$; DMSO- $d_{6}$ ): $\delta 14.49$ (s, $\left.1 \mathrm{H}\right), 9.24(\mathrm{br} \mathrm{s}, 1 \mathrm{H}), 8.45$ (s, $\left.3 \mathrm{H}\right), 8.37(\mathrm{~d}, J=9.3 \mathrm{~Hz}, 1 \mathrm{H}), 8.28$ (br s, $1 \mathrm{H}), 7.95(\mathrm{~d}, J=8.2 \mathrm{~Hz}, 1 \mathrm{H}), 7.78(\mathrm{~s}, 1 \mathrm{H}), 7.54(\mathrm{dd}, J=8.2,1.4 \mathrm{~Hz}, 1 \mathrm{H}), 7.35$ (t, $J$ $=7.9 \mathrm{~Hz}, 1 \mathrm{H}), 7.28(\mathrm{~d}, J=1.8 \mathrm{~Hz}, 1 \mathrm{H}), 7.13-7.05(\mathrm{~m}, 3 \mathrm{H}), 5.34(\mathrm{~s}, 2 \mathrm{H}), 3.99(\mathrm{q}, J=5.7$ $\mathrm{Hz}, 2 \mathrm{H}) .{ }^{13} \mathrm{C}-\mathrm{NMR}\left(126 \mathrm{MHz}\right.$; DMSO- $\left.d_{6}\right): \delta 158.1,154.4,142.8,142.1,135.82,135.69$, 129.8, 129.0, 123.8, 121.5, 120.3, 115.7, 115.1, 114.6, 113.8, 68.5, 42.1; ESIMS m/z (rel. intensity) $280\left(\mathrm{MH}^{+}, 100\right)$; HRMS calcd for $\mathrm{C}_{17} \mathrm{H}_{18} \mathrm{~N}_{3} \mathrm{O}$ : 280.1450 ; found: 280.1442 .

\section{7-[(Pyridin-3-yloxy)methyl]quinolin-2-amine Dihydrochloride (11)}

This was prepared from $26(0.120 \mathrm{~g}, 0.43 \mathrm{mmol})$ and 3-hydroxypyridine $(0.041 \mathrm{~g}, 0.43$ mmol). Workup and purification by trituration with $50 \% \mathrm{CH}_{2} \mathrm{Cl}_{2}$ in hexanes $(4 \mathrm{~mL})$ afforded intermediate acetamide $\mathbf{7 4}$ as a flocculent, peach-colored solid $(0.068 \mathrm{~g}, 54 \%)$, which was deprotected using $\mathrm{K}_{2} \mathrm{CO}_{3}(0.064 \mathrm{~g}, 0.466 \mathrm{mmol})$. After workup, the resulting 
residue was triturated with $\mathrm{DCM} / \mathrm{hexanes}(\sim 4 \mathrm{~mL})$, and the pale-yellow iridescent solid was collected, dissolved in $\mathrm{MeOH}$, filtered to remove particulates, and concentrated. The residue was resuspended in $\mathrm{MeOH}(1 \mathrm{~mL})$ and methanolic $\mathrm{HCl}(1.5 \mathrm{~mL})$ was added. After $5 \mathrm{~min}$, the addition of ether $(5 \mathrm{~mL})$ precipitated $\mathbf{1 1}$ as an off-white solid $(0.067 \mathrm{~g}, 88 \%$ from $\mathbf{7 4})$ after washing with ether $\left(2 \mathrm{~mL}\right.$ ): $\mathrm{mp} 188^{\circ} \mathrm{C}$ (softens), $211-214{ }^{\circ} \mathrm{C}$ (melts). ${ }^{1} \mathrm{H}-\mathrm{NMR}$ (500 MHz; DMSO- $d_{6}$ ): $\delta 14.35$ (s, $\left.1 \mathrm{H}\right), 9.23$ (br s, $\left.1 \mathrm{H}\right), 8.65$ (s, $\left.1 \mathrm{H}\right), 8.43$ (s, $\left.1 \mathrm{H}\right), 8.38$ (d, $J=$ 9.3 Hz, $1 \mathrm{H}), 8.27$ (br s, $1 \mathrm{H}), 7.98-7.97(\mathrm{~m}, 2 \mathrm{H}), 7.79$ (s, $1 \mathrm{H}), 7.76-7.74(\mathrm{~m}, 1 \mathrm{H}), 7.57$ (d, $J=8.1 \mathrm{~Hz}, 1 \mathrm{H}), 7.13-7.11(\mathrm{~m}, 1 \mathrm{H}), 5.51(\mathrm{~s}, 2 \mathrm{H})$; the pyridinium $\mathrm{N}-\mathrm{H}$ proton is broadened into the baseline and is not visible; ${ }^{13} \mathrm{C}-\mathrm{NMR}$ (126 MHz; DMSO- $d_{6}$ ): $\delta 155.7,154.6,143.0$, 140.9, 138.2, 135.9, 133.6, 129.3, 127.7, 126.5, 124.2, 120.7, 115.7, 114.2, 69.7; ESIMS m/z (rel. intensity) $252\left(\mathrm{MH}^{+}, 100\right)$; HRMS calcd for $\mathrm{C}_{15} \mathrm{H}_{14} \mathrm{~N}_{3} \mathrm{O}$ : 252.1137; found: 252.1130 .

\section{7-((3-(Dimethylamino)phenoxy)methyl)quinolin-2-amine Dihydrochloride (12)}

This was prepared from $26(0.120 \mathrm{~g}, 0.43 \mathrm{mmol})$ and 3-(dimethylamino)phenol $(0.041 \mathrm{~g}$, $0.43 \mathrm{mmol}$ ). After workup, the resulting residue was purified by flash column chromatography, eluting with a gradient of $5 \% \mathrm{EtOAc}$ in $\mathrm{CH}_{2} \mathrm{Cl}_{2}$ to $25 \% \mathrm{EtOAc}$ in $\mathrm{CH}_{2} \mathrm{Cl}_{2}$, to yield intermediate acetamide $\mathbf{6 5}(0.070 \mathrm{~g}, 49 \%)$ as a clear syrup, which was immediately deprotected using $\mathrm{K}_{2} \mathrm{CO}_{3}(0.058 \mathrm{~g}, 0.42 \mathrm{mmol})$. After workup, the resulting oil was treated with methanolic $\mathrm{HCl}(4 \mathrm{~mL})$, and ether $(12 \mathrm{~mL})$ was added to afford an off-white solid; an analytically pure sample for assay was prepared by preparative LC-MS, using the instrument described in the General Procedures section and a Phenomenex Luna $5 \mu \mathrm{m} \mathrm{C8(2)} 100 \AA$, $150 \times 21.2 \mathrm{~mm}$ preparative HPLC column, eluting with a gradient of $95 \% \mathrm{H}_{2} \mathrm{O}+0.1 \%$ formic acid $/ 5 \% \mathrm{MeCN}+0.1 \%$ formic acid to $81 \% \mathrm{H}_{2} \mathrm{O}+0.1 \%$ formic acid $/ 19 \% \mathrm{MeCN}+$ $0.1 \%$ formic acid over $20 \mathrm{~min}$. Evaporation of the desired mass fraction and retreatment with methanolic $\mathrm{HCl}(1 \mathrm{~mL})$ and ether $(1 \mathrm{~mL})$ afforded $\mathbf{1 2}$ as a white solid $(0.023 \mathrm{~g}, 30 \%$ from 65): mp 195-197 ${ }^{\circ} \mathrm{C} .{ }^{1} \mathrm{H}-\mathrm{NMR}\left(500 \mathrm{MHz}\right.$; DMSO- $d_{6}$ ): $\delta 14.30$ (s, $\left.1 \mathrm{H}\right), 9.22$ (br s, 1 $\mathrm{H}), 8.38(\mathrm{~d}, J=9.5 \mathrm{~Hz}, 1 \mathrm{H}), 8.22(\mathrm{br} \mathrm{s}, 1 \mathrm{H}), 7.95(\mathrm{~d}, J=9.0 \mathrm{~Hz}, 1 \mathrm{H}), 7.77(\mathrm{~s}, 1 \mathrm{H}), 7.55$ $(\mathrm{d}, J=9.0 \mathrm{~Hz}, 1 \mathrm{H}), 7.27(\mathrm{~s}, 1 \mathrm{H}), 7.11(\mathrm{~d}, J=9.0 \mathrm{~Hz}, 1 \mathrm{H}), 6.68(\mathrm{br} \mathrm{s}, 3 \mathrm{H}), 5.32(\mathrm{~s}, 2 \mathrm{H})$, 2.99 (s, $6 \mathrm{H})$; one proton is not visible due to baseline broadening; ${ }^{13} \mathrm{C}-\mathrm{NMR}$ (126 MHz; DMSO- $\left.d_{6}\right): \delta 159.4,154.8,143.4,142.9,136.3,130.6,129.4,124.4,120.8,115.6,114.2$, 66.9 ; four of the aryl carbons are not visible due to baseline broadening and the methyl carbon signals are obscured by the solvent peak; ESIMS $m / z$ (rel. intensity) $294\left(\mathrm{MH}^{+}, 100\right)$; HRMS calcd for $\mathrm{C}_{18} \mathrm{H}_{20} \mathrm{~N}_{3} \mathrm{O}, 294.1606$; found, 294.1599.

\section{7-[(3-(3-(Dimethylamino)propyl)phenoxy)methyl]quinolin-2-amine Dihydrochloride (13)}

This was prepared from $26(0.150 \mathrm{~g}, 0.54 \mathrm{mmol})$ and phenol 49 (0.097 g, $0.54 \mathrm{mmol})$. Workup and purification by flash column chromatography, eluting with a gradient of $2 \%$ $\mathrm{MeOH}$ in EtOAc to $40 \% \mathrm{MeOH}$ in EtOAc, afforded intermediate acetamide $\mathbf{6 6}$ as a pale yellow gum $(0.105 \mathrm{~g}, 51 \%)$ after filtering an EtOAc solution to remove particulates and reconcentrating. The intermediate acetamide was deprotected using $\mathrm{K}_{2} \mathrm{CO}_{3}(0.077 \mathrm{~g}, 0.556$ mmol). After workup, the resulting residue was diluted in $\mathrm{CH}_{2} \mathrm{Cl}_{2}(1 \mathrm{~mL})$ and precipitated with hexanes $(5 \mathrm{~mL})$ to yield the free aminoquinoline as a white solid, which was diluted with $\mathrm{CH}_{2} \mathrm{Cl}_{2}$, filtered again, and concentrated. The residue was diluted in ether $(5 \mathrm{~mL})$ and treated with methanolic $\mathrm{HCl}(1 \mathrm{~mL})$ for $5 \mathrm{~min}$. The mixture was then concentrated, and the residue was triturated with ether $(2 \times 5 \mathrm{~mL}), 10 \% \mathrm{MeOH}$ in ether $(4 \times 5 \mathrm{~mL})$, and EtOAc $(5$ 
$\mathrm{ml}$ ), to yield 13 as an off-white foam $\left(0.045 \mathrm{~g}, 40 \%\right.$ from 66): $\mathrm{mp} 72-75^{\circ} \mathrm{C}$ (softens), 260 ${ }^{\circ} \mathrm{C}$ (dec). ${ }^{1} \mathrm{H}-\mathrm{NMR}\left(500 \mathrm{MHz}\right.$; DMSO- $d_{6}$ ): $\delta 14.34$ (s, $\left.1 \mathrm{H}\right), 10.41$ (s, $\left.1 \mathrm{H}\right), 9.17$ (br s, $1 \mathrm{H}$ ), $8.37(\mathrm{~d}, J=9.3 \mathrm{~Hz}, 1 \mathrm{H}), 8.21(\mathrm{br} \mathrm{s}, 1 \mathrm{H}), 7.95(\mathrm{~d}, J=8.2 \mathrm{~Hz}, 1 \mathrm{H}), 7.77(\mathrm{~s}, 1 \mathrm{H}), 7.54$ (dd, $J$ $=8.2,1.3 \mathrm{~Hz}, 1 \mathrm{H}), 7.24(\mathrm{t}, J=7.9 \mathrm{~Hz}, 1 \mathrm{H}), 7.10(\mathrm{~d}, J=9.3 \mathrm{~Hz}, 1 \mathrm{H}), 6.96(\mathrm{t}, J=1.8 \mathrm{~Hz}, 1$ H), 6.90-6.88 (m, $1 \mathrm{H}), 6.85(\mathrm{~d}, J=7.7 \mathrm{~Hz}, 1 \mathrm{H}), 5.31(\mathrm{~s}, 2 \mathrm{H}), 3.02-2.99(\mathrm{~m}, 2 \mathrm{H}), 2.72(\mathrm{~s}, 3$ $\mathrm{H}), 2.72(\mathrm{~s}, 3 \mathrm{H}), 2.61(\mathrm{t}, J=7.7 \mathrm{~Hz}, 2 \mathrm{H}), 2.00-1.94(\mathrm{~m}, 2 \mathrm{H}) .{ }^{13} \mathrm{C}-\mathrm{NMR}(126 \mathrm{MHz}$; DMSO- $\left.d_{6}\right): \delta 158.1,154.4,142.8,142.36,142.27,135.9,129.6,129.0,123.8,121.1,120.3$, 115.12, 115.01, 113.7, 112.3, 68.3, 56.1, 42.0, 31.9, 25.1; ESIMS $m / z$ (rel. intensity) 336 $\left(\mathrm{MH}^{+}, 100\right)$; HRMS calcd for $\mathrm{C}_{21} \mathrm{H}_{26} \mathrm{~N}_{3} \mathrm{O}, 336.2076$; found, 336.2073 .

\section{7-((3-(2-(Dimethylamino)ethoxy)phenoxy)methyl)quinolin-2-amine Dihydrochloride (14)}

This was prepared from $26(0.100 \mathrm{~g}, 0.36 \mathrm{mmol})$ and phenol $42(0.065 \mathrm{~g}, 0.36 \mathrm{mmol})$. After workup, the resulting residue was purified by flash column chromatography, eluting with $50 \%$ EtOAc in hexanes $+5 \% \mathrm{Et}_{3} \mathrm{~N}$, to yield intermediate acetamide $67(0.050 \mathrm{~g}, 37 \%)$ as an opaque syrup, which was immediately deprotected using $\mathrm{K}_{2} \mathrm{CO}_{3}(0.036 \mathrm{~g}, 0.26 \mathrm{mmol})$. After workup, the resulting oil was treated with methanolic $\mathrm{HCl}(3 \mathrm{M}, 3 \mathrm{~mL})$, and ether (9 $\mathrm{mL}$ ) was added, affording an off-white solid; an analytically pure sample for assay was prepared by preparative LC-MS, using the instrument described in the General Procedures section, and a Phenomenex Luna $5 \mu \mathrm{m} \mathrm{C} 8(2) 100 \AA$, $150 \times 21.2 \mathrm{~mm}$ preparative HPLC column, eluting with a gradient of $99 \% \mathrm{H}_{2} \mathrm{O}+0.1 \%$ formic acid $/ 1 \% \mathrm{MeCN}+0.1 \%$ formic acid to $98 \% \mathrm{H}_{2} \mathrm{O}+0.1 \%$ formic acid $2 \% \mathrm{MeCN}+0.1 \%$ formic acid over $20 \mathrm{~min}$. Evaporation of the desired mass fraction and retreatment with methanolic $\mathrm{HCl}(1 \mathrm{~mL})$ and ether $(1 \mathrm{~mL})$ afforded 14 as a white solid $(0.0065 \mathrm{~g}, 12 \%$, from 67$)$ : $\mathrm{mp} 181-183{ }^{\circ} \mathrm{C} .{ }^{1} \mathrm{H}-$ NMR (500 MHz; DMSO- $\left.d_{6}\right): \delta 14.43(\mathrm{~s}, 1 \mathrm{H}), 10.57(\mathrm{~s}, 1 \mathrm{H}), 9.24(\mathrm{br} \mathrm{s}, 1 \mathrm{H}), 8.37(\mathrm{~d}, J=$ $9.0 \mathrm{~Hz}, 1 \mathrm{H}), 8.23(\mathrm{br} \mathrm{s}, 1 \mathrm{H}), 7.95(\mathrm{~d}, J=8.0 \mathrm{~Hz}, 1 \mathrm{H}), 7.77(\mathrm{~s}, 1 \mathrm{H}), 7.53(\mathrm{~d}, J=8.0 \mathrm{~Hz}, 1$ $\mathrm{H}), 7.24(\mathrm{dd}, J=8.0,8.0 \mathrm{~Hz}, 1 \mathrm{H}), 7.11(\mathrm{~d}, J=9.0 \mathrm{~Hz}, 1 \mathrm{H}), 6.72-6.67(\mathrm{~m}, 2 \mathrm{H}), 6.62(\mathrm{dd}$, $J=8.0,2.5 \mathrm{~Hz}, 1 \mathrm{H}), 5.32(\mathrm{~s}, 2 \mathrm{H}), 4.36(\mathrm{t}, J=5.0 \mathrm{~Hz}, 2 \mathrm{H}), 3.48(\mathrm{dt}, J=5.0,5.0 \mathrm{~Hz}, 2 \mathrm{H})$, 2.83 (s, $6 \mathrm{H}) ;{ }^{13} \mathrm{C}-\mathrm{NMR}\left(126 \mathrm{MHz}\right.$; DMSO- $\left.d_{6}\right): \delta 159.7,159.2,154.9 .143 .2,142.6,136.3$, 130.7, 129.5, 124.2, 120.8, 115.8, 114.2, 108.2, 108.0, 102.5, 69.0, 62.8, 55.7, 48.2. ESIMS $m / z$ (rel. intensity) $338\left(\mathrm{MH}^{+}, 100\right)$; HRMS calcd for $\mathrm{C}_{20} \mathrm{H}_{24} \mathrm{~N}_{3} \mathrm{O}_{2}, 338.1868$; found, 338.1864 .

\section{7-[(4-(Dimethylamino)methyl)phenoxy)methyl]quinolin-2-amine Dihydrochloride (15)}

This was prepared from $26(0.120 \mathrm{~g}, 0.43 \mathrm{mmol})$ and phenol $44(0.065 \mathrm{~g}, 0.43 \mathrm{mmol})$. Workup and purification by flash column chromatography, eluting with a gradient of $3 \%$ $\mathrm{MeOH}$ in EtOAc to $20 \% \mathrm{MeOH}$ in EtOAc, afforded crude acetamide $\mathbf{6 8}$ as a foamy paleyellow semisolid $(0.099 \mathrm{~g}, 66 \%)$, which was deprotected using $\mathrm{K}_{2} \mathrm{CO}_{3}(0.078 \mathrm{~g}, 0.57$ mmol). After workup, the resulting yellowish gum was triturated with $10 \%$ EtOAc in hexanes $(10 \mathrm{~mL})$, diluted with $\mathrm{MeOH}$, filtered, and re-concentrated. The resulting residue was diluted with ether $(5 \mathrm{~mL})$ and treated with methanolic $\mathrm{HCl}(1 \mathrm{~mL})$ for $5 \mathrm{~min}$.

Concentration afforded an off-white foamy solid; an analytically pure sample for assay was prepared by preparative LC-MS, using the instrument described in the General Procedures section, and a Phenomenex Luna $5 \mu \mathrm{m} \mathrm{C} 8(2) 100 \AA$, $150 \times 21.2 \mathrm{~mm}$ preparative HPLC column, eluting with a gradient of $95 \% \mathrm{H}_{2} \mathrm{O}+0.1 \%$ formic acid $/ 5 \% \mathrm{MeCN}+0.1 \%$ formic 
acid to $80 \% \mathrm{H}_{2} \mathrm{O}+0.1 \%$ formic acid $20 \% \mathrm{MeCN}+0.1 \%$ formic acid over $20 \mathrm{~min}$. Evaporation of the desired mass fraction yielded a syrup that was suspended in $\mathrm{MeOH}(2$ $\mathrm{mL})$, filtered, concentrated, and treated with methanolic $\mathrm{HCl}(0.7 \mathrm{~mL})$. Ether $(5 \mathrm{~mL})$ was added to precipitate $\mathbf{1 5}$, which was obtained as a white hygroscopic solid $(0.022 \mathrm{~g}, 21 \%$ from 68) after washing with ether and drying: mp $251-253.5{ }^{\circ} \mathrm{C} .{ }^{1} \mathrm{H}-\mathrm{NMR}(500 \mathrm{MHz}$; DMSO- $d_{6}$ ): $\delta 14.27$ (s, $\left.1 \mathrm{H}\right), 10.50(\mathrm{~s}, 1 \mathrm{H}), 9.15(\mathrm{br} \mathrm{s}, 1 \mathrm{H}), 8.37$ (d, $\left.J=9.3 \mathrm{~Hz}, 1 \mathrm{H}\right), 8.21$ (br s, $1 \mathrm{H}), 7.95(\mathrm{~d}, J=8.2 \mathrm{~Hz}, 1 \mathrm{H}), 7.76(\mathrm{~s}, 1 \mathrm{H}), 7.55-7.54(\mathrm{~m}, 1 \mathrm{H}), 7.50(\mathrm{~d}, J=8.7 \mathrm{~Hz}, 2$ H), $7.12(\mathrm{~d}, J=8.7 \mathrm{~Hz}, 2 \mathrm{H}), 7.10(\mathrm{~d}, J=9.4 \mathrm{~Hz}, 1 \mathrm{H}), 5.35(\mathrm{~s}, 2 \mathrm{H}), 4.19(\mathrm{~d}, J=4.7 \mathrm{~Hz}, 2$ H), 2.66 (s, $3 \mathrm{H}), 2.65$ (s, $3 \mathrm{H}$ ); ${ }^{13} \mathrm{C}-\mathrm{NMR}\left(126 \mathrm{MHz}\right.$; DMSO- $\left.d_{6}\right)$ : $\delta 158.8,154.4,142.8$, 142.0, 135.9, 132.7, 129.0, 123.8, 122.8, 120.4, 115.22, 115.02, 113.8, 68.5, 58.9, 41.3; ESIMS $m / z$ (rel. intensity) $308\left(\mathrm{MH}^{+}, 100\right)$; HRMS calcd for $\mathrm{C}_{19} \mathrm{H}_{22} \mathrm{~N}_{3} \mathrm{O}, 308.1763$; found, 308.1756.

\section{7-[(4-(Methylamino)methyl)phenoxy)methyl]quinolin-2-amine Dihydrochloride (16)}

This was prepared from $26(0.150 \mathrm{~g}, 0.54 \mathrm{mmol})$ and phenol $45(0.128 \mathrm{~g}, 0.54 \mathrm{mmol})$. Workup and purification by flash column chromatography, eluting with a gradient of $5 \%$ EtOAc in $\mathrm{CH}_{2} \mathrm{Cl}_{2}$ to $33 \%$ EtOAc in $\mathrm{CH}_{2} \mathrm{Cl}_{2}$, afforded intermediate acetamide $\mathbf{6 9}$ as a pale yellow foam (0.184 g, 78\%), which was deprotected using $\mathrm{K}_{2} \mathrm{CO}_{3}(0.117 \mathrm{~g}, 0.844 \mathrm{mmol})$. After workup, the resulting residue was purified by flash column chromatography, eluting with a gradient of EtOAc to $2 \% \mathrm{MeOH}$ in EtOAc, to yield a colorless foam. The free aminoquinoline was diluted with ether $(7 \mathrm{~mL})$ and treated with methanolic $\mathrm{HCl}(1.5 \mathrm{~mL})$ for $18 \mathrm{~h}$. The precipitate was filtered to yield $\mathbf{1 6}$ as a white chalky solid $(0.131 \mathrm{~g}, 85 \%$ from $\mathbf{6 9})$ after washing with $20 \% \mathrm{MeOH}$ in ether $(5 \mathrm{~mL})$ and drying: $\mathrm{mp} 283-285{ }^{\circ} \mathrm{C} .{ }^{1} \mathrm{H}-\mathrm{NMR}(500$ MHz; DMSO- $d_{6}$ ): $\delta 14.31$ (s, $1 \mathrm{H}$ ), 9.07 (br s, $3 \mathrm{H}$ ), 8.36 (d, $J=9.3 \mathrm{~Hz}, 1 \mathrm{H}$ ), 8.29 (br s, 1 H), $7.94(\mathrm{~d}, J=8.2 \mathrm{~Hz}, 1 \mathrm{H}), 7.75(\mathrm{~s}, 1 \mathrm{H}), 7.53(\mathrm{dd}, J=8.2,1.3 \mathrm{~Hz}, 1 \mathrm{H}), 7.47-7.45$ (m, 2 H), 7.10-7.09 (m, $3 \mathrm{H}), 5.35(\mathrm{~s}, 2 \mathrm{H}), 4.03(\mathrm{t}, J=5.6 \mathrm{~Hz}, 2 \mathrm{H}), 2.48(\mathrm{~m}, 3 \mathrm{H}$, partially obscured by solvent peak). ${ }^{13} \mathrm{C}-\mathrm{NMR}\left(126 \mathrm{MHz}\right.$; DMSO- $\left.d_{6}\right): \delta 158.4,154.4,142.7,142.0$, 136.0, 131.6, 129.0, 124.5, 123.7, 120.4, 115.2, 114.9, 113.7, 68.5, 50.6, 31.7; ESIMS m/z (rel. intensity) $294\left(\mathrm{MH}^{+}, 100\right)$; HRMS calcd for $\mathrm{C}_{18} \mathrm{H}_{20} \mathrm{~N}_{3} \mathrm{O}, 294.1606$; found, 294.1597.

\section{7-[((3-((Dimethylamino)methyl)phenyl)amino)methyl]quinolin-2-amine Trihydrochloride (17)}

Aldehyde 81 ( $0.080 \mathrm{~g}, 0.374 \mathrm{mmol})$ and aniline $48(0.067 \mathrm{~g}, 0.449 \mathrm{mmol})$ were diluted in abs. EtOH $(12 \mathrm{~mL})$ and anhydrous $\mathrm{Na}_{2} \mathrm{SO}_{4}(\sim 0.5 \mathrm{~g})$ was added. The mixture was heated to $60{ }^{\circ} \mathrm{C}$ for $1 \mathrm{~h}$, glacial $\mathrm{AcOH}(8 \mu \mathrm{L})$ was added, and heating was continued for $22 \mathrm{~h}$. The mixture was cooled to room temperature, and $\mathrm{NaBH}_{4}(0.018 \mathrm{~g}, 0.486 \mathrm{mmol})$ was added, and after $20 \mathrm{~min}$, the mixture was filtered. The filtrate was evaporated and partitioned between EtOAc and sat. aq. $\mathrm{NaHCO}_{3}(20 \mathrm{~mL}$ each). The aqueous layer was extracted with EtOAc (2 $\times 30 \mathrm{~mL}$ ), and the organic layer was washed with $\mathrm{H}_{2} \mathrm{O}$ and sat. aq. $\mathrm{NaCl}(20 \mathrm{~mL}$ each), dried over anhydrous sodium sulfate, and concentrated. The resulting residue was purified by flash column chromatography, eluting with a gradient of $\mathrm{CH}_{2} \mathrm{Cl}_{2}$ to $25 \% \mathrm{MeOH}$ in $\mathrm{CH}_{2} \mathrm{Cl}_{2}$, to yield the crude acetamide as a white solid $(0.032 \mathrm{~g}, 25 \%)$ after trituration with $10 \%$ $\mathrm{CH}_{2} \mathrm{Cl}_{2}$ in hexanes. The intermediate acetamide was deprotected using $\mathrm{K}_{2} \mathrm{CO}_{3}(0.026 \mathrm{~g}$, $0.188 \mathrm{mmol}$ ), worked up using the General Procedure; the obtained yellow gum was triturated with $10 \%$ EtOAc in hexanes and hexanes ( $3 \mathrm{~mL}$ each), diluted with $20 \% \mathrm{MeOH}$ in ether $(\sim 5 \mathrm{~mL})$, and treated with methanolic $\mathrm{HCl}(0.5 \mathrm{~mL})$ for $5 \mathrm{~min}$. The precipitate was 
collected, diluted in $\mathrm{MeOH}(0.5 \mathrm{~mL})$, and precipitated with ether $(3 \mathrm{~mL})$ to afford 17 (0.019 $\mathrm{g}, 12 \%$ from the acetamide) as a pale-yellow powder: $\mathrm{mp} 219-221{ }^{\circ} \mathrm{C} ;{ }^{1} \mathrm{H}-\mathrm{NMR}(500 \mathrm{MHz}$; DMSO- $\left.d_{6}\right): \delta 14.18(\mathrm{~s}, 1 \mathrm{H}), 10.35(\mathrm{~s}, 1 \mathrm{H}), 9.11(\mathrm{br} \mathrm{s}, 1 \mathrm{H}), 8.33(\mathrm{~d}, J=9.3 \mathrm{~Hz}, 1 \mathrm{H}), 8.12$ (br s, $1 \mathrm{H}), 7.87(\mathrm{~d}, J=8.2 \mathrm{~Hz}, 1 \mathrm{H}), 7.64(\mathrm{~s}, 1 \mathrm{H}), 7.48(\mathrm{dd}, J=8.2,1.3 \mathrm{~Hz}, 1 \mathrm{H}), 7.11(\mathrm{t}, J$ $=7.8 \mathrm{~Hz}, 1 \mathrm{H}), 7.04(\mathrm{~d}, J=9.3 \mathrm{~Hz}, 1 \mathrm{H}), 6.75(\mathrm{~s}, 1 \mathrm{H}), 6.68(\mathrm{~d}, J=7.5 \mathrm{~Hz}, 1 \mathrm{H}), 6.63(\mathrm{dd}, J$ $=8.2,1.6 \mathrm{~Hz}, 1 \mathrm{H}), 4.49(\mathrm{~s}, 2 \mathrm{H}), 4.07(\mathrm{~d}, J=5.5 \mathrm{~Hz}, 2 \mathrm{H}), 2.63(\mathrm{~s}, 3 \mathrm{H}), 2.62(\mathrm{~s}, 3 \mathrm{H})$; the anilinium $\mathrm{N}-\mathrm{H}$ protons appear as a broad singlet, exchanging with residual water at 4.2 ppm; ${ }^{13} \mathrm{C}-\mathrm{NMR}$ (126 MHz; DMSO- $d_{6}$ ): $\delta$ 154.3, 148.5, 145.9, 142.9, 135.8, 131.1, 129.4, $128.8,124.3,119.8,118.3,114.7,114.1,113.5,113.1,60.0,46.1,41.5$; ESIMS $m / z$ (rel. intensity) $307\left(\mathrm{MH}^{+}, 100\right)$; HRMS calcd for $\mathrm{C}_{19} \mathrm{H}_{23} \mathrm{~N}_{4}, 307.1923$; found, 307.1916.

\section{7-[((3-((Methylamino)methyl)phenyl)amino)methyl]quinolin-2-amine Trihydrochloride (18)}

Bromide 26 (0.092 g, $0.330 \mathrm{mmol})$, aniline 50 (0.195 g, $0.826 \mathrm{mmol})$, and $\mathrm{KI}(0.006 \mathrm{~g}, 15$ $\mathrm{mol} \%$ ) were combined in anhydrous $\mathrm{MeCN}(2.5 \mathrm{~mL})$, sealed, and heated under microwave irradiation at $110^{\circ} \mathrm{C}$ for $20 \mathrm{~min}$. The mixture was diluted with $\mathrm{CH}_{2} \mathrm{Cl}_{2}(30 \mathrm{~mL})$ and washed with sat. aq. $\mathrm{NaHCO}_{3}(20 \mathrm{~mL})$. The aqueous layer was extracted with $\mathrm{CH}_{2} \mathrm{Cl}_{2}(20 \mathrm{~mL})$ and the organic layers were washed with $\mathrm{H}_{2} \mathrm{O}$ and sat. aq. $\mathrm{NaCl}(30 \mathrm{~mL})$, dried over anhydrous sodium sulfate, and concentrated. The residue was purified by flash column chromatography, eluting with a gradient of $5 \% \mathrm{EtOAc}$ in $\mathrm{CH}_{2} \mathrm{Cl}_{2}$ to $40 \% \mathrm{EtOAc}$ in $\mathrm{CH}_{2} \mathrm{Cl}_{2}$, to yield intermediate acetamide $\mathbf{7 5}$ as a yellow foam $(0.103 \mathrm{~g}, 72 \%)$, which was deprotected using $\mathrm{K}_{2} \mathrm{CO}_{3}(0.065 \mathrm{~g}, 0.474 \mathrm{mmol})$ and worked up according to the General Procedure. The resulting residue was purified by flash column chromatography, eluting with a gradient of EtOAc to $2 \% \mathrm{MeOH}$ in EtOAc, to yield a pale-yellow foam. The free aminoquinoline was diluted with $30 \% \mathrm{MeOH}$ in ether $(11 \mathrm{~mL})$ and was treated with methanolic $\mathrm{HCl}(1.5$ $\mathrm{mL})$ for $20 \mathrm{~h}$. The precipitate was collected and precipitated from hot $\mathrm{MeOH}(0.5 \mathrm{~mL})$ with ether $(5 \mathrm{~mL})$ to yield 18 as a cream-colored solid $(0.050 \mathrm{~g}, 53 \%$ from $\mathbf{7 5})$ : $\mathrm{mp} 230-232$ ${ }^{\circ} \mathrm{C} .{ }^{1} \mathrm{H}-\mathrm{NMR}\left(500 \mathrm{MHz}\right.$; DMSO- $d_{6}$ ): $\delta 14.30$ (s, $\left.1 \mathrm{H}\right), 9.10$ (br s, $\left.3 \mathrm{H}\right), 8.34$ (d, J = 9.3 Hz, 1 $\mathrm{H}), 8.16(\mathrm{br} \mathrm{s}, 1 \mathrm{H}), 7.88(\mathrm{~d}, J=8.2 \mathrm{~Hz}, 1 \mathrm{H}), 7.65(\mathrm{~s}, 1 \mathrm{H}), 7.49(\mathrm{dd}, J=8.2,1.3 \mathrm{~Hz}, 1 \mathrm{H})$, $7.09(\mathrm{t}, J=7.8 \mathrm{~Hz}, 1 \mathrm{H}), 7.06(\mathrm{~d}, J=9.3 \mathrm{~Hz}, 1 \mathrm{H}), 6.76(\mathrm{~s}, 1 \mathrm{H}), 6.68(\mathrm{~d}, J=7.5 \mathrm{~Hz}, 1 \mathrm{H})$, $6.60(\mathrm{dd}, J=8.1,1.7 \mathrm{~Hz}, 1 \mathrm{H}), 4.49$ (s, $2 \mathrm{H}), 3.92$ (t, $J=5.9 \mathrm{~Hz}, 2 \mathrm{H}), 2.47$ (t, $J=5.4 \mathrm{~Hz}, 3$ $\mathrm{H}$, partially obscured by solvent peak); the anilinium $\mathrm{N}-\mathrm{H}$ protons appear as a broad singlet, exchanging with residual water at $4.4 \mathrm{ppm} ;{ }^{13} \mathrm{C}-\mathrm{NMR}\left(126 \mathrm{MHz}\right.$; DMSO- $\left.d_{6}\right): \delta 154.5$, 148.5, 146.1, 143.0, 136.0, 132.9, 129.5, 129.0, 124.4, 120.0, 117.6, 114.9, 113.6, 113.24, 113.19, 51.7, 46.4, 32.1; ESIMS $\mathrm{m} / z$ (rel. intensity) $293\left(\mathrm{MH}^{+}, 100\right)$; HRMS calcd for $\mathrm{C}_{18} \mathrm{H}_{21} \mathrm{~N}_{4}, 293.1766$; found, 293.1760.

\section{7-[(4-Fluoro-3-((methylamino)methyl)phenoxy)methyl]quinolin-2-amine Dihydrochloride (19)}

This was prepared from $26(0.100 \mathrm{~g}, 0.358 \mathrm{mmol})$ and phenol $54(0.091 \mathrm{~g}, 0.358 \mathrm{mmol})$. Workup and purification by flash column chromatography, eluting with $2 \%$ EtOAc in $\mathrm{CH}_{2} \mathrm{Cl}_{2}$ to $30 \%$ EtOAc in $\mathrm{CH}_{2} \mathrm{Cl}_{2}$, afforded intermediate acetamide $\mathbf{7 0}$ as a colorless foam $(0.128 \mathrm{~g}, 79 \%)$, which was immediately deprotected using $\mathrm{K}_{2} \mathrm{CO}_{3}(0.078 \mathrm{~g}, 0.564 \mathrm{mmol})$. After workup, the resulting gum was triturated with hexanes $(2 \times 5 \mathrm{~mL})$, diluted in $10 \%$ $\mathrm{MeOH}$ in ether $(9 \mathrm{~mL})$ and treated with methanolic $\mathrm{HCl}(1.5 \mathrm{~mL})$ for $20 \mathrm{~h}$. The precipitate was collected and precipitated 3 times from hot $\mathrm{MeOH}(0.5 \mathrm{~mL})$ with ether $(2.5 \mathrm{~mL})$ to yield 
19 as a white amorphous solid (0.053 g, 49\% from 70): mp 293-294 ${ }^{\circ} \mathrm{C} .{ }^{1} \mathrm{H}-\mathrm{NMR}(500$ MHz; DMSO- $d_{6}$ ): $\delta 14.35$ (s, $1 \mathrm{H}$ ), 9.29 (br s, $3 \mathrm{H}$ ), 8.37 (d, $J=9.3 \mathrm{~Hz}, 1 \mathrm{H}$ ), 8.29 (br s, 1 H), $7.95(\mathrm{~d}, J=8.2 \mathrm{~Hz}, 1 \mathrm{H}), 7.78(\mathrm{~s}, 1 \mathrm{H}), 7.54(\mathrm{dd}, J=8.2,1.3 \mathrm{~Hz}, 1 \mathrm{H}), 7.44(\mathrm{dd}, J=6.0$, $3.1 \mathrm{~Hz}, 1 \mathrm{H}), 7.27(\mathrm{t}, J=9.2 \mathrm{~Hz}, 1 \mathrm{H}), 7.14(\mathrm{dt}, J=8.9,3.6 \mathrm{~Hz}, 1 \mathrm{H}), 7.10(\mathrm{~d}, J=9.3 \mathrm{~Hz}, 1$ $\mathrm{H}), 5.33(\mathrm{~s}, 2 \mathrm{H}), 4.14(\mathrm{~s}, 2 \mathrm{H}), 2.57(\mathrm{~s}, 3 \mathrm{H}) ;{ }^{13} \mathrm{C} \mathrm{NMR}\left(126 \mathrm{MHz}\right.$; DMSO- $\left.d_{6}\right): \delta(156.0+$ 154.04, 1 C), 154.4, (154.11 + 154.10, 1 C), 142.8, 141.8, 136.0, 129.0, 123.8, 120.4, $(119.89+119.76,1 \mathrm{C}),(118.18+118.15,1 \mathrm{C}),(117.10+117.03,1 \mathrm{C}),(116.53+116.35,1$ C), 115.3, 113.8, 69.2, (44.44 + 44.41, $1 \mathrm{C}), 32.2$; ESIMS $\mathrm{m} / \mathrm{z}$ (rel. intensity) $312\left(\mathrm{MH}^{+}\right.$, 100); HRMS calcd for $\mathrm{C}_{18} \mathrm{H}_{19} \mathrm{FN}_{3} \mathrm{O}, 312.1512$; found, 312.1502 .

\section{7-[(4-Chloro-3-((methylamino)methyl)phenoxy)methyl]quinolin-2-amine Dihydrochloride (20)}

This was prepared from $26(0.100 \mathrm{~g}, 0.358 \mathrm{mmol})$ and phenol $55(0.097 \mathrm{~g}, 0.358 \mathrm{mmol})$. Workup and purification by flash column chromatography, eluting with $2 \%$ EtOAc in $\mathrm{CH}_{2} \mathrm{Cl}_{2}$ to $30 \%$ EtOAc in $\mathrm{CH}_{2} \mathrm{Cl}_{2}$, afforded intermediate acetamide $\mathbf{7 1}$ as a colorless foam $(0.136 \mathrm{~g}, 81 \%)$, which was deprotected using $\mathrm{K}_{2} \mathrm{CO}_{3}(0.080 \mathrm{~g}, 0.578 \mathrm{mmol})$. After workup, the resulting gum was triturated with hexanes $(2 \times 5 \mathrm{~mL})$, diluted in $10 \% \mathrm{MeOH}$ in ether $(9$ $\mathrm{mL})$, and treated with methanolic $\mathrm{HCl}(1.5 \mathrm{~mL})$ for $20 \mathrm{~h}$. The precipitate was collected and precipitated 4 times from hot $\mathrm{MeOH}(1 \mathrm{~mL})$ with ether $(3 \mathrm{~mL})$ to yield $\mathbf{2 0}$ as a white amorphous solid (0.059 g, 51\% from 71): $\mathrm{mp} 290-291.5^{\circ} \mathrm{C}$ (dec). ${ }^{1} \mathrm{H}-\mathrm{NMR}(500 \mathrm{MHz}$; DMSO- $d_{6}$ ): $\delta 14.36$ (s, $\left.1 \mathrm{H}\right), 9.21$ (br s, $\left.3 \mathrm{H}\right), 8.37$ (d, $\left.J=9.3 \mathrm{~Hz}, 1 \mathrm{H}\right), 8.27$ (br s, $\left.1 \mathrm{H}\right), 7.95$ $(\mathrm{d}, J=8.2 \mathrm{~Hz}, 1 \mathrm{H}), 7.77(\mathrm{~s}, 1 \mathrm{H}), 7.54(\mathrm{dd}, J=5.2,2.2 \mathrm{~Hz}, 2 \mathrm{H}), 7.49(\mathrm{~d}, J=8.9 \mathrm{~Hz}, 1 \mathrm{H})$, $7.14(\mathrm{dd}, J=8.9,3.0 \mathrm{~Hz}, 1 \mathrm{H}), 7.10(\mathrm{~d}, J=9.3 \mathrm{~Hz}, 1 \mathrm{H}), 5.37$ (s, $2 \mathrm{H}), 4.21(\mathrm{~s}, 2 \mathrm{H}), 2.60$ (s, $3 \mathrm{H}) ;{ }^{13} \mathrm{C}-\mathrm{NMR}\left(126 \mathrm{MHz}\right.$; DMSO- $\left.d_{6}\right): \delta 156.9,154.4,142.7,141.5,135.9,130.9,130.5$, 129.1, 124.9, 123.8, 120.4, 118.3, 117.0, 115.4, 113.8, 69.0, 48.3, 32.4; ESIMS $m / z$ (rel. intensity) $328\left(\mathrm{MH}^{+}, 100\right)$; HRMS calcd for $\mathrm{C}_{18} \mathrm{H}_{19} \mathrm{ClN}_{3} \mathrm{O}$, 328.1217; found, 328.1212.

\section{7-[((5-((Methylamino)methyl)pyridin-3-yl)oxy)methyl]quinolin-2-amine Trihydrochloride (21)}

This was prepared from 26 ( $0.100 \mathrm{~g}, 0.358 \mathrm{mmol})$ and phenol $\mathbf{5 9}(0.085 \mathrm{~g}, 0.358 \mathrm{mmol})$. Workup and purification by flash column chromatography, eluting with $15 \%$ EtOAc in $\mathrm{CH}_{2} \mathrm{Cl}_{2}$ to $90 \%$ EtOAc in $\mathrm{CH}_{2} \mathrm{Cl}_{2}$, afforded intermediate acetamide $\mathbf{7 3}$ as a white amorphous solid (0.098 g, 63\%), which was deprotected using $\mathrm{K}_{2} \mathrm{CO}_{3}(0.062 \mathrm{~g}, 0.449$ $\mathrm{mmol})$. After workup, the resulting gum was triturated with hexanes $(2 \times 5 \mathrm{~mL})$, diluted in $10 \% \mathrm{MeOH}$ in ether $(9 \mathrm{~mL})$ and treated with methanolic $\mathrm{HCl}(1.5 \mathrm{~mL})$ for $20 \mathrm{~h}$. The precipitate was collected and precipitated from hot $\mathrm{MeOH}(0.5 \mathrm{~mL})$ with ether $(2.5 \mathrm{~mL})$ to yield 21 as a flocculent, cream-colored solid $(0.056 \mathrm{~g}, 62 \%$ from 73$)$ : $\mathrm{mp} 224-226{ }^{\circ} \mathrm{C} .{ }^{1} \mathrm{H}$ NMR (500 MHz; DMSO- $d_{6}$ ): $\delta 14.36$ (s, $\left.1 \mathrm{H}\right), 9.47$ (s, $2 \mathrm{H}$ ), 9.23 (br s, $\left.1 \mathrm{H}\right), 8.51$ (d, $J=2.7$ $\mathrm{Hz}, 1 \mathrm{H}), 8.38$ (d, $J=9.4 \mathrm{~Hz}, 2 \mathrm{H}), 8.26$ (br s, $1 \mathrm{H}), 7.97$ (d, $J=8.2 \mathrm{~Hz}, 2 \mathrm{H}), 7.80(\mathrm{~s}, 1 \mathrm{H})$, $7.56(\mathrm{dd}, J=8.2,1.4 \mathrm{~Hz}, 1 \mathrm{H}), 7.11(\mathrm{~d}, J=9.3 \mathrm{~Hz}, 1 \mathrm{H}), 5.46(\mathrm{~s}, 2 \mathrm{H}), 4.18(\mathrm{t}, J=5.8 \mathrm{~Hz}, 2$ H), 2.54 (t, $J=5.4 \mathrm{~Hz}, 3 \mathrm{H}) ;{ }^{13} \mathrm{C}-\mathrm{NMR}\left(126 \mathrm{MHz}\right.$; DMSO- $\left.d_{6}\right)$ : $\delta 154.54,154.42,143.0$, 142.3, 141.2, 137.1, 136.0, 129.51, 129.32, 125.2, 124.2, 120.7, 115.6, 114.1, 69.4, 48.3, 32.1; ESIMS $m / z$ (rel. intensity) $295\left(\mathrm{MH}^{+}, 100\right)$; HRMS calcd for $\mathrm{C}_{17} \mathrm{H}_{19} \mathrm{~N}_{4} \mathrm{O}, 295.1559$; found, 295.1553. 
(RS)-7-[(3-(1-(Methylamino)ethyl)phenoxy)methyl]quinolin-2-amine Ditifluoroacetate (22)

This was prepared from $26(0.100 \mathrm{~g}, 0.36 \mathrm{mmol})$ and phenol $56(0.090 \mathrm{~g}, 0.36 \mathrm{mmol})$. After workup, the resulting residue was purified by flash column chromatography, eluting with a gradient of $7 \% \mathrm{EtOAc}$ in $\mathrm{CH}_{2} \mathrm{Cl}_{2}$, to $30 \%$ EtOAc in $\mathrm{CH}_{2} \mathrm{Cl}_{2}$ to yield intermediate acetamide 72 as a white solid $(0.119 \mathrm{~g}, 74 \%)$, which was immediately deprotected using $\mathrm{K}_{2} \mathrm{CO}_{3}(0.073$ $\mathrm{g}, 0.53 \mathrm{mmol})$. After workup, the resulting oil was treated with trifluoroacetic acid $(\sim 0.3$ $\mathrm{mL})$ in ether $(5 \mathrm{~mL})$ and stirred at room temperature $18 \mathrm{~h}$ to afford 22 as a white solid $(0.077$ g, 50\% from 72): mp $120-123{ }^{\circ} \mathrm{C} .{ }^{1} \mathrm{H}-\mathrm{NMR}\left(500 \mathrm{MHz}\right.$; DMSO- $\left.d_{6}\right): \delta 14.37$ (s, $\left.1 \mathrm{H}\right), 9.15$ (s, $1 \mathrm{H}), 8.92$ (br s, $2 \mathrm{H}), 8.39$ (d, $J=9.5 \mathrm{~Hz}, 1 \mathrm{H}), 7.97$ (d, $J=8.5 \mathrm{~Hz}, 1 \mathrm{H}), 7.72(\mathrm{~s}, 1 \mathrm{H}), 7.56$ $(\mathrm{d}, J=9.5 \mathrm{~Hz}, 1 \mathrm{H}), 7.42(\mathrm{dd}, J=8.0,8.0 \mathrm{~Hz}, 1 \mathrm{H}), 7.23(\mathrm{dd}, J=2.0,1.5 \mathrm{~Hz}, 1 \mathrm{H}), 7.14-$ $7.05(\mathrm{~m}, 3 \mathrm{H}), 5.34(\mathrm{~s}, 2 \mathrm{H}), 4.30(\mathrm{q}, J=6.0 \mathrm{~Hz}, 1 \mathrm{H}), 2.44(\mathrm{t}, J=5.0 \mathrm{~Hz}, 3 \mathrm{H}), 1.54(\mathrm{~d}, J=$ $6.0 \mathrm{~Hz}, 3 \mathrm{H}) ;{ }^{13} \mathrm{C}-\mathrm{NMR}(126 \mathrm{MHz}$, DMSO-d6) $\delta(159.5+159.2+159.0+158.7,1 \mathrm{C})$, $158.8,155.1,143.3,142.4,139.1,136.7,130.8,129.5,124.3,120.9,120.7,115.7,115.6$, 114.8, 114.4, 103.5, 69.1, 58.3, 30.9, 19.3; ESIMS $\mathrm{m} / z$ (rel. intensity) $308\left(\mathrm{MH}^{+}, 100\right)$; HRMS calcd for $\mathrm{C}_{19} \mathrm{H}_{22} \mathrm{~N}_{3} \mathrm{O}, 308.1763$; found, 308.1755 .

\section{(E)-Methyl 4-(2-Cyanovinyl)-3-nitrobenzoate (77). ${ }^{23}$}

Compound $76(2.00 \mathrm{~g}, 9.56 \mathrm{mmol})$ was diluted in anhydrous $\mathrm{CH}_{2} \mathrm{Cl}_{2}(24 \mathrm{~mL})$ and cooled to $-15{ }^{\circ} \mathrm{C}$. (Triphenylphosphoranylidene)acetonitrile (3.08 g, $10.2 \mathrm{mmol}$ ) was diluted in anhydrous $\mathrm{CH}_{2} \mathrm{Cl}_{2}(30 \mathrm{~mL})$ and added to the reaction mixture dropwise over $50 \mathrm{~min}$. The mixture was stirred a total of $90 \mathrm{~min}$, warmed to room temperature, and concentrated. The residue was purified by flash column chromatography, eluting with a gradient of $10 \%$ EtOAc in hexanes to 35\% EtOAc in hexanes. Fractions containing pure $\mathbf{7 7}$ were saved, and the remaining eluate was concentrated and repurified using the same column gradient to yield 77 as a white flocculent solid $(1.76 \mathrm{~g}, 79 \%) ;{ }^{1} \mathrm{H}-\mathrm{NMR}\left(500 \mathrm{MHz}, \mathrm{CDCl}_{3}\right) \delta 8.72(\mathrm{~d}, J$ $=1.7 \mathrm{~Hz}, 1 \mathrm{H}), 8.32(\mathrm{dd}, J=8.1,1.7 \mathrm{~Hz}, 1 \mathrm{H}), 7.87(\mathrm{~d}, J=8.1 \mathrm{~Hz}, 1 \mathrm{H}), 7.69(\mathrm{~d}, J=11.8$ $\mathrm{Hz}, 1 \mathrm{H}), 5.77(\mathrm{~d}, J=11.8 \mathrm{~Hz}, 1 \mathrm{H}), 3.94(\mathrm{~s}, 3 \mathrm{H}) ;{ }^{13} \mathrm{C}-\mathrm{NMR}\left(126 \mathrm{MHz}, \mathrm{CDCl}_{3}\right) \delta 164.2$, 147.1, 145.7, 134.7, 133.3, 132.8, 131.1, 126.2, 115.6, 101.5, 53.0; ESIMS m/z (rel. intensity) $233\left(\mathrm{MH}^{+}, 100\right)$;

\section{Methyl 2-Aminoquinoline-7-carboxylate (78). ${ }^{23}$}

Compound $77(2.2 \mathrm{~g}, 9.47 \mathrm{mmol})$ was diluted in DMF/glacial AcOH $(1: 1,20 \mathrm{~mL})$ and one portion of iron powder $(1.85 \mathrm{~g}, 33.2 \mathrm{mmol}$, divided into two roughly equal amounts) was added in smaller portions. The mixture was heated to $100{ }^{\circ} \mathrm{C}$ for $90 \mathrm{~min}$, after which the second portion of iron was added in smaller portions. After a total of $2 \mathrm{~h} 50$ min of heating, the mixture was cooled, concentrated to dryness, and the mixture was treated with sat. aq. $\mathrm{NaHCO}_{3}(100 \mathrm{~mL})$. This mixture was exhaustively extracted with EtOAc (total, $700 \mathrm{~mL}$ ), and the organic phase was washed with sat. aq. $\mathrm{NaCl}(200 \mathrm{~mL})$, dried over anhydrous sodium sulfate, and concentrated. The resulting yellow residue was diluted with EtOAc (10 $\mathrm{mL})$ and heated until dissolution occurred. Hexanes $(100 \mathrm{~mL})$ were then added, and the mixture was sonicated vigorously until a precipitate formed. The precipitate was collected and washed with hexanes to yield $\mathbf{7 8}$ as a pale-yellow crystalline solid $(1.59 \mathrm{~g}, 83 \%) .{ }^{1} \mathrm{H}-$ NMR $\left(500 \mathrm{MHz}, \mathrm{CDCl}_{3}\right) \delta 8.40(\mathrm{~s}, 1 \mathrm{H}), 7.96(\mathrm{~d}, J=8.8 \mathrm{~Hz}, 1 \mathrm{H}), 7.91(\mathrm{dd}, J=8.3,1.6 \mathrm{~Hz}$, $1 \mathrm{H}), 7.70(\mathrm{~d}, J=8.3 \mathrm{~Hz}, 1 \mathrm{H}), 6.87(\mathrm{~d}, J=8.8 \mathrm{~Hz}, 1 \mathrm{H}), 5.19(\mathrm{~s}, 2 \mathrm{H}), 3.99(\mathrm{~s}, 3 \mathrm{H}) ;{ }^{13} \mathrm{C}-$ 
NMR (126 MHz, $\left.\mathrm{CDCl}_{3}\right) \delta 167.0,157.1,146.0,138.2,131.4,127.8,127.6,126.1,122.8$, 113.8, 52.4; ESIMS m/z (rel. intensity) $203\left(\mathrm{MH}^{+}, 100\right)$.

\section{Methyl 2-Acetamidoquinoline-7-carboxylate (79)}

Compound $78(1.89 \mathrm{~g}, 9.37 \mathrm{mmol})$ was diluted with anhydrous dioxane $(60 \mathrm{~mL})$, and $\mathrm{N}$ acetylimidazole $(1.24 \mathrm{~g}, 11.2 \mathrm{mmol})$ and a catalytic amount $(\sim 0.050 \mathrm{~g})$ of DMAP were added. The mixture was heated at $100{ }^{\circ} \mathrm{C}$ for $19 \mathrm{~h}$, cooled, and concentrated, and the resulting residue was suspended in $\mathrm{CH}_{2} \mathrm{Cl}_{2}(300 \mathrm{~mL})$. The organic layer was washed with $\mathrm{H}_{2} \mathrm{O}(200 \mathrm{~mL})$, and the aqueous layer was extracted with $\mathrm{CH}_{2} \mathrm{Cl}_{2}(2 \times 200 \mathrm{~mL})$. The organic layers were washed with $\mathrm{H}_{2} \mathrm{O}(400 \mathrm{~mL})$ and sat. aq. $\mathrm{NaCl}(300 \mathrm{~mL})$, dried over anhydrous sodium sulfate, and concentrated. The residue was diluted in $\mathrm{CH}_{2} \mathrm{Cl}_{2}(10 \mathrm{~mL})$, and hexanes $(150 \mathrm{~mL})$ were added until a precipitate formed. This was collected and dried to yield $\mathbf{7 9}$ as a tan iridescent solid $(2.08 \mathrm{~g}, 91 \%)$ : $\mathrm{mp} 218-219.5^{\circ} \mathrm{C} .{ }^{1} \mathrm{H}-\mathrm{NMR}\left(500 \mathrm{MHz}, \mathrm{CDCl}_{3}\right) \delta 8.68$ (br s, $1 \mathrm{H}), 8.56-8.49(\mathrm{~m}, 2 \mathrm{H}), 8.22(\mathrm{~d}, J=9.0 \mathrm{~Hz}, 1 \mathrm{H}), 8.06(\mathrm{dd}, J=8.4,1.7 \mathrm{~Hz}, 1 \mathrm{H})$, $7.85(\mathrm{~d}, J=8.4 \mathrm{~Hz}, 1 \mathrm{H}), 4.00(\mathrm{~s}, 3 \mathrm{H}), 2.28(\mathrm{~s}, 3 \mathrm{H}) ;{ }^{13} \mathrm{C}-\mathrm{NMR}\left(126 \mathrm{MHz}, \mathrm{CDCl}_{3}\right) \delta 169.3$, 166.8, 151.8, 145.8, 138.4, 131.4, 129.8, 128.7, 127.9, 124.7, 116.2, 52.5, 24.9; ESIMS $\mathrm{m} / \mathrm{z}$ (rel. intensity) $245\left(\mathrm{MH}^{+}, 100\right)$.

\section{N-(7-(Hydroxymethyl)quinolin-2-yl)acetamide (80)}

Compound $79(0.732 \mathrm{~g}, 3.0 \mathrm{mmol})$ was diluted in anhydrous THF $(10 \mathrm{~mL})$ and cooled to $-15{ }^{\circ} \mathrm{C}$. $\mathrm{LiAlH}_{4}(1 \mathrm{M}$ in THF, $4.5 \mathrm{~mL}, 4.5 \mathrm{mmol}$ ) was added dropwise over $5 \mathrm{~min}$, and the mixture was stirred for $1 \mathrm{~h}$. The reaction was quenched by the addition of EtOAc $(10 \mathrm{~mL})$ and sat. aq. sodium potassium tartrate solution $(20 \mathrm{~mL})$ and stirred until two layers formed. The layers were separated, and the aqueous layer was extracted with EtOAc $(4 \times 50 \mathrm{~mL})$. The organic phase was washed with sat. aq. $\mathrm{NH}_{4} \mathrm{Cl}(50 \mathrm{~mL})$, the aqueous phase was reextracted with $20 \mathrm{~mL}$ EtOAc following this wash, and the combined organic layers were washed with sat. aq. $\mathrm{NaCl}(50 \mathrm{~mL})$, and dried over anhydrous sodium sulfate. Concentration afforded a white residue, which was precipitated from minimal EtOAc with hexanes to afford crude 80 as a white solid $(0.433 \mathrm{~g}, 67 \%)$, which was used in the following step without further purification; ${ }^{1} \mathrm{H}-\mathrm{NMR}\left(500 \mathrm{MHz}, \mathrm{CDCl}_{3}\right) \delta 8.41(\mathrm{~d}, J=8.9 \mathrm{~Hz}, 1 \mathrm{H}), 8.32$ $(\mathrm{s}, 1 \mathrm{H}), 8.17(\mathrm{~d}, J=8.9 \mathrm{~Hz}, 1 \mathrm{H}), 7.81(\mathrm{~s}, 1 \mathrm{H}), 7.79(\mathrm{~d}, J=8.3 \mathrm{~Hz}, 1 \mathrm{H}), 7.47(\mathrm{~d}, J=8.3$ $\mathrm{Hz}, 1 \mathrm{H}), 4.91$ (s, $2 \mathrm{H}), 2.28$ (s, $3 \mathrm{H}) ;{ }^{13} \mathrm{C}$ NMR $\left(126 \mathrm{MHz}, \mathrm{CDCl}_{3}\right) \delta 169.1,151.1,146.6$, 143.1, 138.5, 127.9, 125.6, 124.5, 124.3, 114.0, 65.0, 25.0; ESIMS $m / z$ (rel. intensity) 217 $\left(\mathrm{MH}^{+}, 100\right)$

\section{$\mathrm{N}$-(7-Formylquinolin-2-yl)acetamide (81)}

Dess-Martin periodinane $(0.869 \mathrm{~g}, 2.05 \mathrm{mmol})$ was diluted in anhydrous $\mathrm{CH}_{2} \mathrm{Cl}_{2}(25 \mathrm{~mL})$, and alcohol $80(0.364 \mathrm{~g}, 1.71 \mathrm{mmol})$ was added in one portion. The mixture was stirred at room temperature for $70 \mathrm{~min}$ and then quenched by the addition of sat. aq. $\mathrm{Na}_{2} \mathrm{~S}_{2} \mathrm{O}_{3}(15$ $\mathrm{mL}$ ). After being stirred for $15 \mathrm{~min}$, the layers were separated, and the aqueous layer was extracted with $\mathrm{CH}_{2} \mathrm{Cl}_{2}(2 \times 20 \mathrm{~mL})$. The organic layers were washed with sat. aq. $\mathrm{NaHCO}_{3}$ and sat. aq. $\mathrm{NaCl}(20 \mathrm{~mL}$ each). The organic layer was dried over anhydrous sodium sulfate, concentrated, and the residue was purified by flash column chromatography, eluting with a gradient of $\mathrm{CH}_{2} \mathrm{Cl}_{2}$ to $40 \%$ EtOAc in $\mathrm{CH}_{2} \mathrm{Cl}_{2}$, to yield $\mathbf{8 1}$ as a yellow amorphous solid 
(0.300 g, 82\%); mp 199-200 ${ }^{\circ} \mathrm{C} .{ }^{1} \mathrm{H}-\mathrm{NMR}\left(500 \mathrm{MHz} ; \mathrm{CDCl}_{3}\right): \delta 10.21(\mathrm{~d}, J=0.5 \mathrm{~Hz}, 1 \mathrm{H})$, 8.57 (br d, $J=9.0 \mathrm{~Hz}, 1 \mathrm{H}), 8.29$ (t, $J=0.7 \mathrm{~Hz}, 1 \mathrm{H}), 8.25(\mathrm{~d}, J=9.0 \mathrm{~Hz}, 1 \mathrm{H}), 7.96$ (dd, $J=$ $8.3,1.4 \mathrm{~Hz}, 1 \mathrm{H}), 7.92(\mathrm{~d}, J=8.4 \mathrm{~Hz}, 1 \mathrm{H}), 2.32(\mathrm{~s}, 3 \mathrm{H})$; the acetamidoquinoline $\mathrm{N}-\mathrm{H}$ proton is broadened into the baseline $\sim 8.3 \mathrm{PPM} ;{ }^{13} \mathrm{C}-\mathrm{NMR}\left(126 \mathrm{MHz} ; \mathrm{CDCl}_{3}\right): \delta 192.0$, $151.9,139.2,137.7,132.3,129.8,129.0,122.6,116.7,26.1$; one of the quinoline carbons is broadened into the baseline and is not visible; ESIMS $\mathrm{m} / z$ (rel. intensity) $215\left(\mathrm{MH}^{+}, 14\right)$.

\section{Purified NOS Enzyme Assays}

Rat and human nNOS, murine macrophage iNOS, bovine eNOS, and rat nNOS double mutant D597N/M336V, were recombinant enzymes, expressed in E. coli and purified as previously reported. ${ }^{49,50,51}$ To test for enzyme inhibition, the hemoglobin capture assay was used to measure nitric oxide production. The assay was performed at $37{ }^{\circ} \mathrm{C}$ in HEPES buffer (100 mM, with $10 \%$ glycerol, $\mathrm{pH}$ 7.4) in the presence of $10 \mu \mathrm{M}_{\mathrm{L}}$-arginine. Also included were $100 \mu \mathrm{M} \mathrm{NADPH}, 0.83 \mathrm{mM} \mathrm{CaCl}_{2}$, approximately 320 units $/ \mathrm{mL}$ of calmodulin, $10 \mu \mathrm{M}$ $\mathrm{H}_{4} \mathrm{~B}$, and human oxyhemoglobin $(3 \mu \mathrm{M})$. For iNOS, $\mathrm{CaCl}_{2}$ and calmodulin were omitted and replaced with HEPES buffer (as neither are required for activation of iNOS). The assay was performed in 96-well plates using a Synergy 4 BioTek hybrid reader, and the dispensing of NOS enzyme and hemoglobin were automated; after $30 \mathrm{sec}$ (maximum delay), NO production was read by monitoring the absorbance at $401 \mathrm{~nm}$ (resulting from the conversion of oxyhemoglobin to methemoglobin). Kinetic readouts were performed for 3 or $5 \mathrm{~min}$. Each compound was assayed at least in duplicate, and seven to nine concentrations (500 $\mu \mathrm{M}-50 \mathrm{nM}$ or $100 \mu \mathrm{M}-10 \mathrm{nM}$ for eNOS and iNOS; $50 \mu \mathrm{M}$ to $5 \mathrm{nM}$ for nNOS) were used to construct dose-response curves. $\mathrm{IC}_{50}$ values were calculated by non-linear regression using GraphPad Prism software, and $K_{\mathrm{i}}$ values were obtained using the Cheng-Prusoff equation ${ }^{52}$ $\left[K_{\mathrm{i}}=\mathrm{IC}_{50} /\left(1+[\mathrm{S}] / K_{\mathrm{m}}\right)\right]^{53}$ with the following $K_{\mathrm{m}}$ values: $1.3 \mu \mathrm{M}$ (rat nNOS), $1.6 \mu \mathrm{M}$ (human nNOS), $8.2 \mu \mathrm{M}$ (murine macrophage iNOS), $1.7 \mu \mathrm{M}$ (bovine eNOS), and $1.9 \mu \mathrm{M}$ (rat nNOS D597N/M336V double mutant). ${ }^{38}$

\section{Inhibitor Complex Crystal Preparation}

The preparations of rat nNOS (wild type or D597n/M336V double mutant), bovine eNOS, and human nNOS heme domains used for crystallographic studies were carried out using the procedures described previously. ${ }^{42,54}$ The rat nNOS heme domain (WT or double mutant, at $9 \mathrm{mg} / \mathrm{mL}$ containing $20 \mathrm{mM}$ histidine), or the bovine eNOS heme domain (at $10 \mathrm{mg} / \mathrm{mL}$ containing $2 \mathrm{mM}$ imidazole) were used for the sitting drop vapor diffusion crystallization setup under conditions previously reported. ${ }^{55,56}$ Human nNOS crystals were obtained with the triple K301R/R354A/G357D mutant heme domain sample at $10 \mathrm{mg} / \mathrm{mL}$. By slightly modifying the original conditions ${ }^{42}$ where the monoclinic $\mathrm{C} 2$ crystals grew, a new crystal form belonging to the $\mathrm{P} 2{ }_{1} 2_{1} 2_{1}$ space group was obtained. ${ }^{42}$ Fresh crystals ( $1-2$ days old) were first passed stepwise through cryoprotectant solutions and then soaked with $10 \mathrm{mM}$ inhibitor for $4-6 \mathrm{~h}$ at $4{ }^{\circ} \mathrm{C}$ before being flash cooled with liquid nitrogen.

\section{X-ray Diffraction Data Collection, Data Processing, and Structural Refinement}

The cryogenic $(100 \mathrm{~K}) \mathrm{X}$-ray diffraction data were collected remotely at the Stanford Synchrotron Radiation Lightsource (SSRL) or Advanced Light Source (ALS) through the 
data collection control software Blu-Ice ${ }^{57}$ and a crystal mounting robot. When a Q315r CCD detector was used, $100-125^{\circ}$ of data were typically collected with $0.5^{\circ}$ per frame. If a Pilatus pixel array detector was used, $140-160^{\circ}$ of fine-sliced data were collected with $0.2^{\circ}$ per frame. Raw CCD data frames were indexed, integrated, and scaled using HKL2000, ${ }^{58}$ but the pixel array data were processed with $\mathrm{XDS}^{59}$ and scaled with Scala (or Aimless). ${ }^{60}$ The binding of inhibitors was detected by initial difference Fourier maps calculated with REFMAC. ${ }^{61}$ The inhibitor molecules were then modeled in COOT $^{62}$ and refined using REFMAC or PHENIX. ${ }^{63}$ Disordering in portions of inhibitors bound in the NOS active sites was often observed, sometimes resulting in poor density quality. However, partial structural features usually could still be visible if the contour level of the sigmaA weighted $2 \mathrm{~m}|\mathrm{Fo}|-$ $\mathrm{D}|\mathrm{Fc}|$ map dropped to $0.5 \sigma$, which afforded the building of reasonable models into the disordered regions. Water molecules were added in REFMAC and checked by COOT. The TLS $^{64}$ protocol was implemented in the final stage of refinements with each subunit as one TLS group. The omit Fo - Fc density maps were calculated by removing inhibitor coordinates from the input PDB file before running one more round of TLS refinement in REFMAC or in PHENIX (simulated annealling protocol with a $2000 \mathrm{~K}$ initial temperature). The resulting map coefficients DELFWT and PHDELWT were used to generate maps. The refined structures were validated in COOT before deposition in the RCSB protein data bank. The crystallographic data collection and structure refinement statistics are summarized in Table S1 of the Supporting Information, with the PDB accession codes included.

\section{Caco-2 Permeability Assay}

Caco-2 monolayer assays were performed by Cyprotex US, LLC (Watertown, MA) using the following standard procedure: Caco-2 cells, grown in tissue culture flasks, were trypsinized, re-suspended, and grown and differentiated in 96-well plates for three weeks; monolayer formation was determined by measuring transport of Lucifer yellow, an impermeable dye. All assays were performed at a concentration of $10 \mu \mathrm{M}$ for $2 \mathrm{~h}$. For apical to basolateral (A-->B) permeability, compounds were added on the apical side (A), with permeation determined at the receiving (basolateral, B) side, where the receiving buffer was removed for analysis by LC/MS/MS using an Agilent 6410 mass spectrometer (ESI, MRM mode) coupled with an Agilent 1200 HPLC, using propranolol as an analytical internal standard. Buffers used were $100 \mu \mathrm{M}$ Lucifer yellow in transport buffer $(1.98 \mathrm{~g} / \mathrm{L}$ glucose in 10 mM HEPES, $1 \times$ Hank's Balanced Salt Solution, pH 6.5) (apical side) and transport buffer, $\mathrm{pH} 7.4$ (basolateral side). Apparent permeability $\left(\mathrm{P}_{\mathrm{app}}\right)$ is expressed using the following equation: $\mathrm{P}_{\mathrm{app}}=(\mathrm{dQ} / \mathrm{dt}) / \mathrm{C}_{0} \mathrm{~A}$, where the numerator is the rate of permeation, $\mathrm{C}_{0}$ is initial concentration, and $\mathrm{A}$ is the monolayer area $\left(0.11 \mathrm{~cm}^{2}\right)$. For bidirectional permeability, the efflux ratio was defined as $\mathrm{P}_{\text {app }}(\mathrm{B}-->\mathrm{A}) / \mathrm{P}_{\text {app }}(\mathrm{A}-->\mathrm{B})$; high efflux ratio values (>3) indicate that a compound may be a substrate for P-gp or other active transport systems.

\section{Supplementary Material}

Refer to Web version on PubMed Central for supplementary material. 


\section{Acknowledgments}

The authors are grateful to the National Institutes of Health (GM049725, to R.B.S., GM057353 to T.L.P., and F32GM109667 to M.A.C.), for support of this work. L.J.R. is currently supported on NIH GM081568 and NSF grant 13-573. P.M. is supported by grants UNCE 204011 and PRVOUK P24/LF1/3 from Charles University, Prague, Czech Republic, and A.P. is supported by a Lambert Fellowship (Chemistry of Life Processes Institute, Northwestern University) and by the Katherine L. Kreighbaum Scholarship (Northwestern University). M.A.C and A.P. wish to thank Drs. Arsen Gaisin and Neha Malik of the Center for Molecular Innovation and Drug Discovery (Northwestern University) for valuable assistance with preparative HPLC, and Mr. Saman Shafaie and Dr. S. Habibi Goudarzi for assistance with HRMS experiments. We also wish to thank the SSRL and ALS beamline staff for their support during X-ray diffraction and data collection. Off-target $K_{\mathrm{i}}$ determinations were generously provided by the National Institute of Mental Health's Psychoactive Drug Screening Program, contract \#HHSN-271-2013-00017-C (NIMH PDSP), directed by Dr. Bryan L. Roth (University of North Carolina at Chapel Hill) and project officer Jamie Driscoll (NIH).

\section{Abbreviations Used}

$\begin{array}{ll}\text { nNOS } & \text { neuronal nitric oxide synthase } \\ \text { iNOS } & \text { inducible nitric oxide synthase } \\ \text { eNOS } & \text { endothelial nitric oxide synthase } \\ \text { FMN } & \text { flavin mononucleotide } \\ \text { H }_{\mathbf{4}} \text { B } & (6 R)-5,6,7,8 \text {-tetrahydrobiopterin } \\ \text { tPSA } & \text { total polar surface area } \\ \text { Papp } & \text { apparent permeability } \\ \text { HEPES } & \text { 4-(2-hydroxyethyl)-1-piperazineethanesulfonic acid, PDSP, psychoactive drug } \\ & \text { screening program } \\ \text { WT } & \text { wild-type. }\end{array}$

\section{References Cited}

1. Hobbs A, Higgs A, Moncada S. Inhibition of nitric oxide synthase as a potential therapeutic target. Annu. Rev. Pharmacol. Toxicol. 1999; 39:191-220. [PubMed: 10331082]

2. Förstermann U, Sessa WC. Nitric oxide synthases: regulation and function. Eur. Heart J. 2012; 33:829-837. [PubMed: 21890489]

3. Torreilles F, Salman-Tabcheh S, Guerin M, Torreilles J. Neurodegenerative disorders: the role of peroxynitrite. Brain Res. Brain Res. Rev. 1999; 30:153-163. [PubMed: 10525172]

4. Uehara T, Nakamura T, Yao D, Shi ZQ, Gu Z, Ma Y, Masliah E, Nomura Y, Lipton SA. SNitrosylated protein-disulphide isomerase links protein misfolding to neurodegeneration. Nature. 2006; 441:513-517. [PubMed: 16724068]

5. Zhang L, Dawson VL, Dawson TM. Role of nitric oxide in Parkinson's disease. Pharmacol. Ther. 2006; 109:33-41. [PubMed: 16005074]

6. Dorheim M-A, Tracey WR, Pollock JS, Grammas P. Nitric oxide synthase activity is elevated in brain microvessels in Alzheimer's disease. Biochem. Biophys. Res. Commun. 1994; 205:659-665. [PubMed: 7528015]

7. Dreschel DA, Estevez AG, Barbeito L, Beckman JS. Nitric oxide-mediated oxidative damage and the progressive demise of motor neurons in ALS. Neurotoxic. Res. 2012; 22:251-264.

8. Huang Z, Huang PL, Panahian N, Dalkara T, Fishman MC, Moskowitz MA. Effects of cerebral ischemia in mice deficient in neuronal nitric oxide synthase. Science. 1994; 265:1883-1885. [PubMed: 7522345] 
9. Hantraye P, Brouillet E, Ferrante R, Palfi S, Dolan R, Matthews RT, Beal MF. Inhibition of neuronal nitric oxide synthase prevents MPTP-induced Parkinsonism in baboons. Nat. Med. 1996; 2:1017-1021. [PubMed: 8782460]

10. Watanabe Y, Kato H, Araki T. Protective action of neuronal nitric oxide synthase inhibitor in the MPTP mouse model of Parkinson's disease. Metab. Brain Dis. 2008; 23:51-69. [PubMed: 18030609]

11. Ikeda K, Iwasaki Y, Kinoshita M. Neuronal nitric oxide synthase inhibitor, 7-nitroindazole, delays motor dysfunction and spinal motoneuron degeneration in the wobbler mouse. J. Neurol. Sci. 1998; 160:9-15. [PubMed: 9804111]

12. Siddhanta U, Presta A, Fan B, Wolan D, Rousseau DL, Stuehr DJ. Domain swapping in inducible NO synthase: electron transfer cccurs between flavin and heme groups located on adjacent subunits in the dimer. J. Biol. Chem. 1998; 273:18950-18958. [PubMed: 9668073]

13. Rosen GM, Tsai P, Pou S. Mechanism of free-radical generation by nitric oxide synthase. Chem. Rev. 2002; 102:1191-1199. [PubMed: 11942793]

14. Alderton WK, Cooper CE, Knowles RG. Nitric oxide synthases: structure, function and inhibition. Biochem. J. 2001; 357:593-615. [PubMed: 11463332]

15. Mukherjee P, Cinelli MA, Kang S, Silverman RB. Development of nitric oxide synthase (NOS) inhibitors for neurodegenerative diseases and neuropathic pain. Chem. Soc. Rev. 2014; 43:68146838. [PubMed: 24549364]

16. Kobayashi Y, Ikeda K, Shinozuka K, Nara Y, Yamori Y, Hattori K. L-nitroarginine increases blood pressure in the rat. Clin. Exp. Pharmacol. Physiol. 1991; 18:397-399. [PubMed: 1914242]

17. Seelig A. The role of size and charge for blood-brain barrier permeation of drugs and fatty acids. J. Mol. Neurosci. 2007; 33:32-41. [PubMed: 17901543]

18. Cinelli MA, Li H, Chreifi G, Martasek P, Roman LJ, Poulos TL, Silverman RB. Simplified 2aminoquinoline-based scaffold for potent and selective neuronal nitric oxide synthase inhibition. J. Med. Chem. 2014; 57:1513-1530. [PubMed: 24472039]

19. Besnard J, Ruda GF, Setola V, Abecassis K, Rodriguiz RM, Huang XP, Norval S, Sassano MF, Shin AI, Webster LA, Simeons FR, Stojanovski L, Prat A, Seidah NG, Constam DB, Bickerton GR, Read KD, Wetsel WC, Gilbert IH, Roth BL, Hopkins AL. Automated design of ligands to polypharmacological profiles. Nature. 2012; 492:215-220. [PubMed: 23235874]

20. Klabunde T, Evers A. GPCR antitarget modeling: pharmacophore models for biogenic amine binding GPCRs to avoid GPCR-mediated side effects. ChemBioChem. 2005; 6:876-889. [PubMed: 15791686]

21. Lowe JA III, Qian W, Volkmann RA, Heck S, Nowakowski J, Nelson R, Nolan C, Liston D, Ward K, Zorn S, Johnson C, Vanase M, Faraci WS, Verdries KA, Baxter J, Doran S, Sanders M, Ashton M, Whittle P, Stefaniak M. A new class of selective and potent inhibitors of neuronal nitric oxide synthase. Bioorg. Med. Chem. Lett. 1999; 9:2569-2572. [PubMed: 10498210]

22. Lowe JA III, Qian W, Drozda SE, Volkmann RA, Nason D, Nelson RB, Nolan C, Liston D, Ward K, Faraci S, Verdries K, Seymour P, Majchrzak M, Villalobos A, White WF. Structure-activity relationships of potent, selective inhibitors of neuronal nitric oxide synthase based on the 6phenyl-2-aminopyridine structure. J. Med. Chem. 2004; 47:1575-1586. [PubMed: 14998342]

23. Nason DM, Heck SD, Bodenstein MS, Lowe JA III, Nelson RB, Liston DR, Nolan CE, Lanyon LF, Ward KM, Volkmann RA. Substituted 6-phenylpyridin-2-ylamines: selective and potent inhibitors of nitric oxide synthase. Bioorg. Med. Chem. Lett. 2004; 14:4511-4514. [PubMed: 15357982]

24. Ramnauth J, Renton P, Dove P, Annedi SC, Speed J, Silverman S, Mladenova G, Maddaford SP, Zinghini S, Rakhit S, Andrews J, Lee DKH, Zhang D, Porreca F. 1,2,3,4-Tetrahydroquinolinebased selective human neuronal nitric oxide synthase (nNOS) inhibitors: lead optimization studies resulting in the identification of $N$-(1-(2-(methylamino)ethyl)-1,2,3,4-tetrahydroquinolin-6yl)thiophene-2-carboximidamide as a preclinical development Candidate. J. Med. Chem. 2012; 55:2882-2983. [PubMed: 22335555]

25. Annedi SC, Ramnauth J, Maddaford SP, Renton P, Rakhit S, Mladenova G, Dove P, Silverman S, Andrews JS, Felice MD, Porreca F. Discovery of cis- $N$-(1-(4-(Methylamino)cyclohexyl)indolin-6yl)thiophene-2-carboximidamide: A 1,6-disubstituted indoline derivative as a highly selective 
inhibitor of human neuronal nitric oxide synthase (nNOS) without any cardiovascular liabilities. J. Med. Chem. 2012; 55:943-955. [PubMed: 22175766]

26. Flinspach M, Li H, Jamal J, Yang W, Huang H, Hah J-M, Gomez-Vidal JA, Litzinger EA, Silverman RB, Poulos TL. Structural basis for dipeptide amide isoform-selective inhibition of neuronal nitric oxide synthase. Nat. Struct. Mol. Biol. 2004; 11:54-59. [PubMed: 14718923]

27. Kang S, Tang W, Li H, Chreifi G, Martasek P, Roman LJ, Poulos TL, Silverman RB. Nitric oxide synthase inhibitors that interact with both heme propionate and tetrahydrobiopterin show high isoform selectivity. J. Med. Chem. 2014; 57:4382-4396. [PubMed: 24758147]

28. Xue F, Li H, Fang J, Roman LJ, Martasek P, Poulos TL, Silverman RB. Peripheral but crucial: A hydrophobic pocket (Tyr706, Leu337, and Met336) for potent and selective inhibition of neuronal nitric oxide synthase. Biooorg. Med. Chem. Lett. 2010; 20:6258-6261.

29. Inglis S, Jones R, Fritz D, Stojkoski C, Booker G, Pyke S. Synthesis of 5-, 6-and 7-substituted-2aminoquinolines as SH3 domain ligands. Org. Biomol. Chem. 2005; 3:2543-2557. [PubMed: 15999186]

30. Kóródi F. A simple new synthetic method for the preparation of 2-aminoquinolines. Synth. Commun. 1991; 21:1841-1846.

31. Smith JA, Jones RK, Booker GW, Pyke SM. Sequential and selective Buchwald-Hartwig amination reactions for the controlled functionalization of 6-bromo-2-chloroquinoline: synthesis of ligands for the Tec Src homology 3 domain. J. Org. Chem. 2008; 78:8880-8892. [PubMed: 18950225]

32. Sun W, Blanton MP, Gabriel JL, Canney DJ. Bioisosteric replacement in the design and synthesis of ligands for nicotinic acetylcholine receptors. Med. Chem. Res. 2005; 14:241-259.

33. Romera JL, Cid JM, Trabanco A. Potassium iodide catalysed monoalkylation of anilines under microwave radiation. Tetrahedron Lett. 2004; 45:8797-8800.

34. Shin G-J, Moon JY, Bae AN, Kim EG, Seo SH. Preparation of quinolinecarboxylic acid-amide derivatives as Fab I inhibitors. Repub. Korean Kongkae Taeho Kongbo. 2009 KR20090063869.

35. Labby KJ, Xue F, Kraus JM, Ji H, Mataka J, Li H, Martásek P, Roman LJ, Poulos TL, Silverman RB. Intramolecular hydrogen bonding: A potential strategy for more bioavailable inhibitors of neuronal nitric oxide synthase. Bioorg. Med. Chem. 2012; 20:2435-2443. [PubMed: 22370337]

36. Hevel JM, Marletta MA. Nitric-oxide synthase assays. Methods Enzymol. 1994; 233:250-258. [PubMed: 7516999]

37. Delker SL, Ji H, Li H, Jamal J, Fang J, Xue F, Silverman RB, Poulos TL. Unexpected binding modes of nitric oxide synthase inhibitors effective in the prevention of cerebral palsy. J. Am. Chem. Soc. 2010; 132:5437-5442. [PubMed: 20337441]

38. Delker SL, Xue F, Li H, Jamal J, Silverman RB, Poulos TL. Role of zinc in isoform-selective inhibitor binding to neuronal nitric oxide synthase. Biochemistry. 2010; 49:10803-10810. [PubMed: 21138269]

39. Mukherjee P, Li J, Sevrioukova I, Chreifi G, Martasek P, Roman LJ, Poulos TL, Silverman RB. Novel 2,4-disubstituted pyrimidines as potent, selective, and cell-permeable inhibitors of neuronal nitric oxide synthase. J. Med. Chem. 2014; 58:1067-1088. [PubMed: 25489882]

40. Huang H, Li H, Martasek P, Roman LJ, Poulos TJ, Silverman RB. Structure-guided design of selective inhibitors of neuronal nitric oxide synthase. J. Med. Chem. 2013; 56:3024-3032. [PubMed: 23451760]

41. Fedorov R, Vasan R, Ghosh DK, Schlichting I. Structures of nitric oxide synthase isoforms complexed with the inhibitor AR-R17477 suggest a rational basis for specificity and inhibitor design. Proc. Nat. Acad. Sci. 2004; 101:5892-5897. [PubMed: 15071192]

42. Kang S, Li H, Tang W, Martásek P, Roman LJ, Poulos TL, Silverman RB. 2-Aminopyridines with a truncated side chain to improve human neuronal nitric oxide synthase inhibitory potency and selectivity. J. Med. Chem. 2015; 58:5548-5560. [PubMed: 26120733]

43. Li H, Jamal J, Plaza C, Pineda SH, Chreifi G, Jing Q, Cinelli MA, Silverman RB, Poulos TL. Crystal structures of human constitutive nitric oxide synthases. Acta Crystallogr., Sect. D: Biol. Crystallogr. 2014; D70:2667-2674. [PubMed: 25286850]

44. Lohmann C, Huwel S, Galla HJ. Predicting blood-brain barrier permeability of drugs: evaluation of different in vitro assays. J. Drug Targeting. 2002; 10:263-276. 
45. Stewart BH, Chan OH, Lu RH, Reyner EL, Shmid HL, Hamilton HW, Steinbaugh BA, Taylor MD. Comparison of intestinal permeabilities determined in multiple in vitro and in situ models: relationship to absorption in humans. Pharm. Res. 1995; 12:693-699. [PubMed: 7479555]

46. Hazeldine ST, Polin L, Kushner J, White K, Bouregeois NM, Crantz B, Palomino E, Corbett TH, Horwitz JP II. Synthesis and biological evaluation of some bioisosteres and congeners of the antitumor agent, 2-\{4-[(7-chloro-2-quinoxalinyl)oxy]phenoxy\}propionic acid (XK469). J. Med. Chem. 2002; 45:3130-3137. [PubMed: 12086498]

47. Hartmann, R.; Marchais-Oberwinkler, S.; Xu, K.; Werth, R. Biaryl derivatives as selective 17-betahydroxysteroid dehydrogenase type 2 inhibitors. US20140057953 A1.

48. Nhu D, Duffy S, Avery VM, Hughes A, Baell JB. Antimalarial 3-arylamino-5benzylamino-1,2,4,5-tetrazines. Bioorg. Med. Chem. Lett. 2010; 20:4496-4498. [PubMed: 20584608]

49. Roman LJ, Sheta EA, Martasek P, Gross SS, Liu Q, Masters BSS. High-level expression of functional rat neuronal nitric oxide synthase in Escherichia coli. Proc. Natl. Acad. Sci. U.S.A. 1995; 92:8428-8432. [PubMed: 7545302]

50. Hevel JM, White KA, Marletta MA. Purification of the inducible murine macrophage nitric oxide synthase: identification as a flavoprotein. J. Biol. Chem. 1991; 266:22789-22791. [PubMed: 1720773]

51. Gerber NC, Ortiz de Montellano PR. Neuronal nitric oxide synthase: expression in Escherichia coli, irreversible inhibition by phenyldiazene, and active site topology. J. Biol. Chem. 1995; 270:17791-17796. [PubMed: 7543092]

52. Cheng Y-C, Prusoff WH. Relationship between the inhibition constant $\left(K_{\dot{\mathrm{j}}}\right)$ and the concentration of the inhibitor which causes 50 per cent inhibition (IC50) of an enzymatic reaction. Biochem. Pharmacol. 1973; 22:3099-3108. [PubMed: 4202581]

54. Li H, Jamal J, Delker S, Plaza C, Ji H, Jing Q, Huang H, Kang S, Silverman RB, Poulos TL. The mobility of a conserved tyrosine residue controls isoform-dependent enzyme-inhibitor interaction in nitric oxide synthases. Biochemistry. 2014; 53:5272-5279. [PubMed: 25089924]

55. Li H, Shimizu H, Flinspach M, Jamal J, Yang W, Xian M, Cai T, Wen EZ, Jia Q, Wang PG, Poulos TL. The novel binding mode of $N$-alkyl- $N$ '-hydroxyguanidine to neuronal nitric oxide synthase provides mechanistic insights into NO biosynthesis. Biochemistry. 2002; 41:13868 13875. [PubMed: 12437343]

56. Raman CS, Li H, Martásek P, Kral V, Masters BSS, Poulos TL. Crystal structure of constitutive endothelial nitric oxide synthase: a paradigm for pterin function involving a novel metal center. Cell. 1998; 95:939-950. [PubMed: 9875848]

57. McPhillips TM, McPhillips SE, Chiu HJ, Cohen AE, Deacon AM, Ellis PJ, Garman E, Gonzalez A, Sauter NK, Phizackerley RP, Soltis SM, Kuhn P. Blu-Ice and the Distributed Control System: software for data acquisition and instrument control at macromolecular crystallography beamlines. J. Synchrotron Radiat. 2002; 9:401-406. [PubMed: 12409628]

58. Otwinowski Z, Minor W. Processing of X-ray diffraction data collected in oscillation mode. Methods Enzymol. 1997; 276:307-326.

59. Kabsch W. XDS. Acta Crystallogr., Sect. D: Biol. Crystallogr. 2010; 66:125-132. [PubMed: 20124692]

60. Evans PR. Scaling and assessment of data quality. Acta Crystallogr., Sect. D: Biol. Crystallogr. 2006; 62:72-82. [PubMed: 16369096]

61. Murshudov GN, Vagin AA, Dodson EJ. Refinement of macromolecular structures by the maximum-likelihood method. Acta Crystallogr. 1997; D53:240-255.

62. Emsley P, Cowtan K. Coot: model-building tools for molecular graphics. Acta Crystallogr. 2004; D60:2126-2132.

63. Adams PD, Afonine PV, Bunkóczi G, Chen VB, Davis IW, Echols N, Headd JJ, Hung L-W, Kapral GJ, Grosse-Kunstleve RW, McCoy AJ, Moriarty NW, Oeffner R, Read RJ, Richardson DC, Richardson JS, Terwilliger TC, Zwart PH. PHENIX: a comprehensive Python-based system for macromolecular structure solution. Acta Crystallogr., Sect. D: Biol. Crystallogr. 2010; D66:213-221. [PubMed: 20124702] 
64. Winn MD, Isupov MN, Murshudov GN. Use of TLS parameters to model anisotropic displacements in macromolecular refinement. Acta Crystallogr. 2001; D57:122-133. 
<smiles>Nc1ccc2ccc(CCNCCc3cccc(F)c3)cc2n1</smiles>
$\times 2 \mathrm{HCl}$<smiles>Nc1ccc2ccc(CCNCCc3cccc(Cl)c3)cc2n1</smiles>
$\times 2 \mathrm{HCl}$

2

Figure 1.

Aminquinoline-containing nNOS inhibitors $\mathbf{1}$ and $\mathbf{2}$ 
A<smiles>[R]c1cccc(CCNCCc2ccc3ccc(N)nc3c2)c1</smiles>
$\times 2 \mathrm{HCl}$

$$
\begin{aligned}
& R=F, 1 \\
& R=C l, 2
\end{aligned}
$$<smiles>Cc1nc2n(c(=O)c1CCN1CCC(c3noc4cc(F)ccc34)CC1)CCCC2</smiles><smiles>O=C(c1ccc(F)cc1)C1CCN(CCn2c(=O)[nH]c3ccccc3c2=O)CC1</smiles><smiles>O=C(CCCN1CCC(O)(c2ccc(Cl)cc2)CC1)c1ccc(F)cc1</smiles>

B<smiles>Nc1cccc(-c2ccc(CCN3CCNCC3)cc2)n1</smiles>
$\mathrm{N}$<smiles>CN(C)CCOc1ccc(-c2cccc(N)n2)c2c1CCCC2</smiles><smiles>CCc1cc(-c2cccc(N)n2)c(OC)cc1OCCN(C)C</smiles>

5<smiles>CN(C)CCc1cccc(OCc2ccc3ccc(N)nc3c2)c1</smiles>

Figure 2.

(A) Similarity of $\mathbf{1}$ and $\mathbf{2}$ to known "promiscuous" CNS binders; (B) truncation-inversion strategy (3 to $\mathbf{4}$ and 5 ) and design of compound 6 


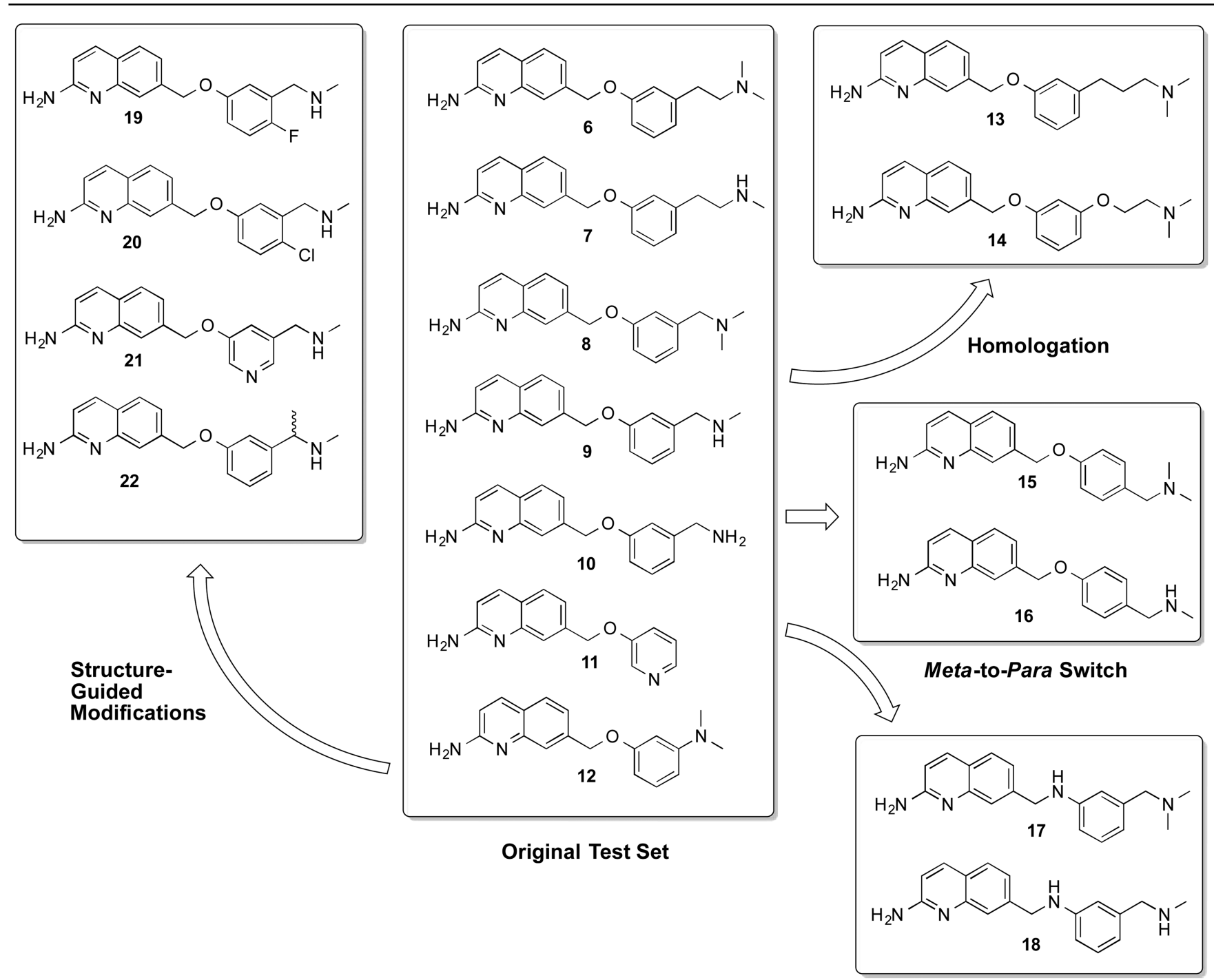

Bioisosteric Replacement

Figure 3.

Molecules investigated in this study and overall design strategy 

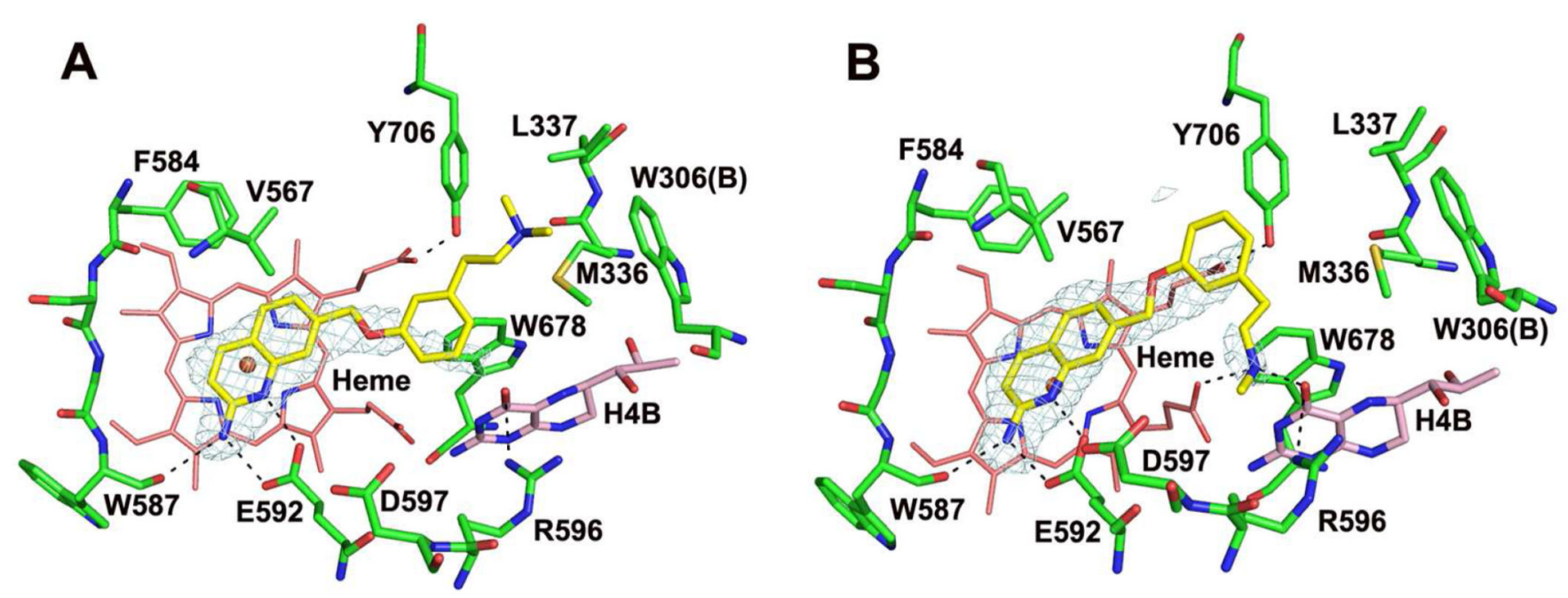

Figure 4.

Active site structure of 6 (A) or 7 (B) bound to rat nNOS. The omit Fo - Fc density map for the inhibitor is shown at the $2.5 \sigma$ contour level. The tail of $\mathbf{6}$ shows weaker density indicative of disordering. The alkylamine of 7 displaces a water molecule, thus making Hbonds with both $\mathrm{H}_{4} \mathrm{~B}$ and heme. Major hydrogen bonds are shown as dashed lines. Figures prepared using PyMol (www.pymol.org) 

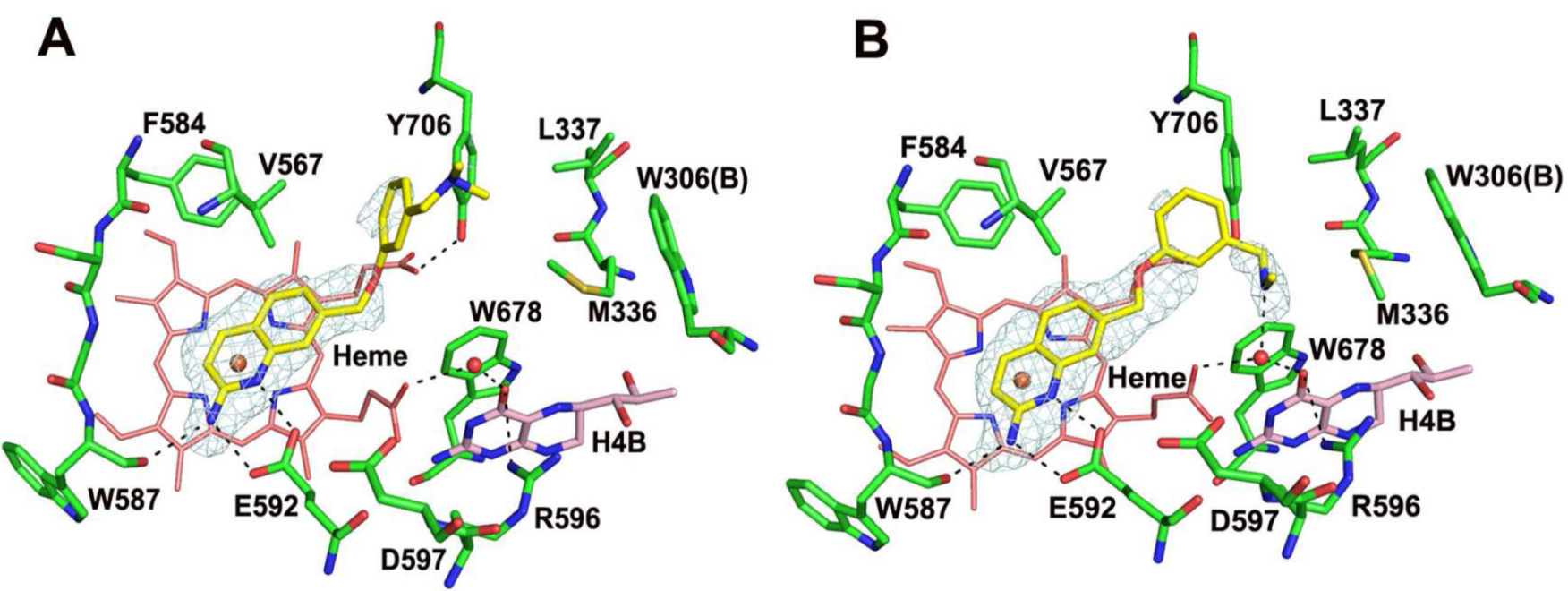

Figure 5.

Active site structure of 8 (A) or 9 (B) bound to rat nNOS. The omit Fo - Fc density map for the inhibitor is shown at the $2.5 \sigma$ contour level. The tail of $\mathbf{8}$ shows weaker density, indicative of disordering. The dimethylamine of $\mathbf{9}$ makes a H-bond with the water molecule bridging both $\mathrm{H}_{4} \mathrm{~B}$ and heme. Major hydrogen bonds are shown as dashed lines. 

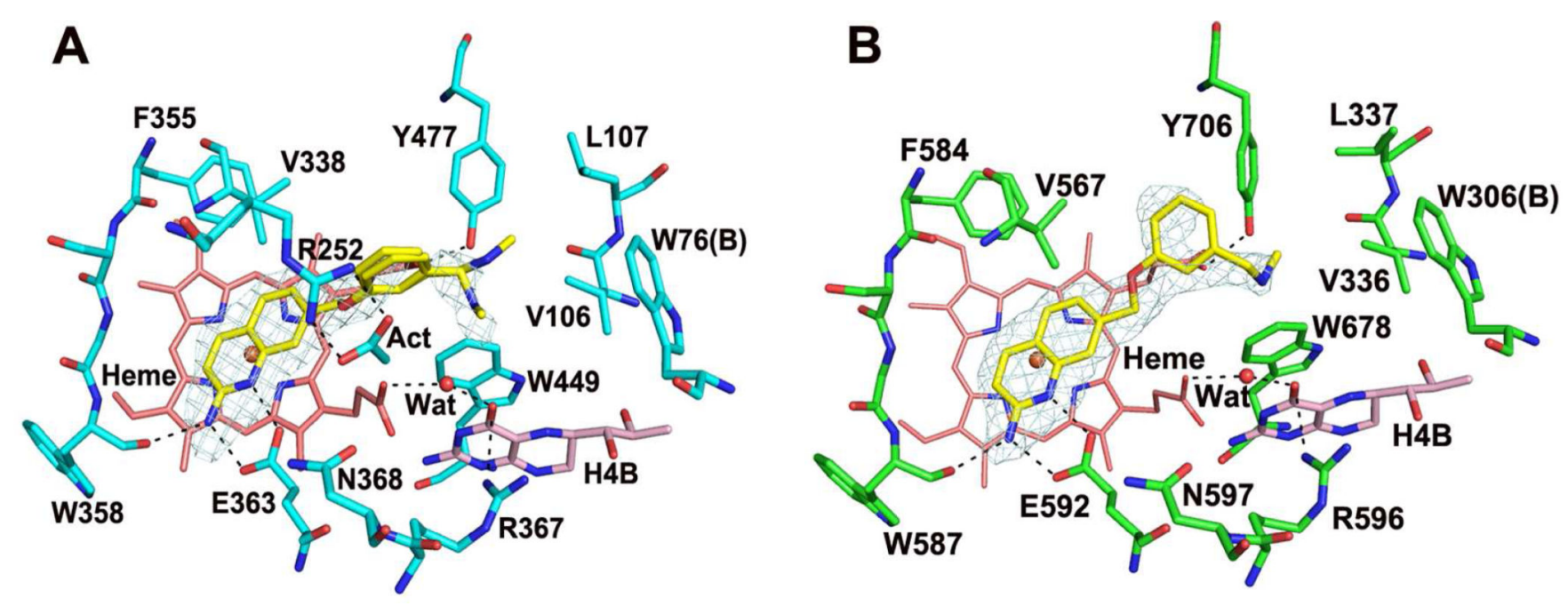

Figure 6.

Active site structure of 9 bound to bovine eNOS (A) and rat nNOS D597N/M336V double mutant (B). The omit Fo - Fc density map for the inhibitor is shown at the $2.5 \sigma$ contour level. An acetate ion (Act) is stabilized by Arg252 in eNOS, which in turn makes contacts with the phenyl ring of 9 . Major hydrogen bonds are shown as dashed lines. 


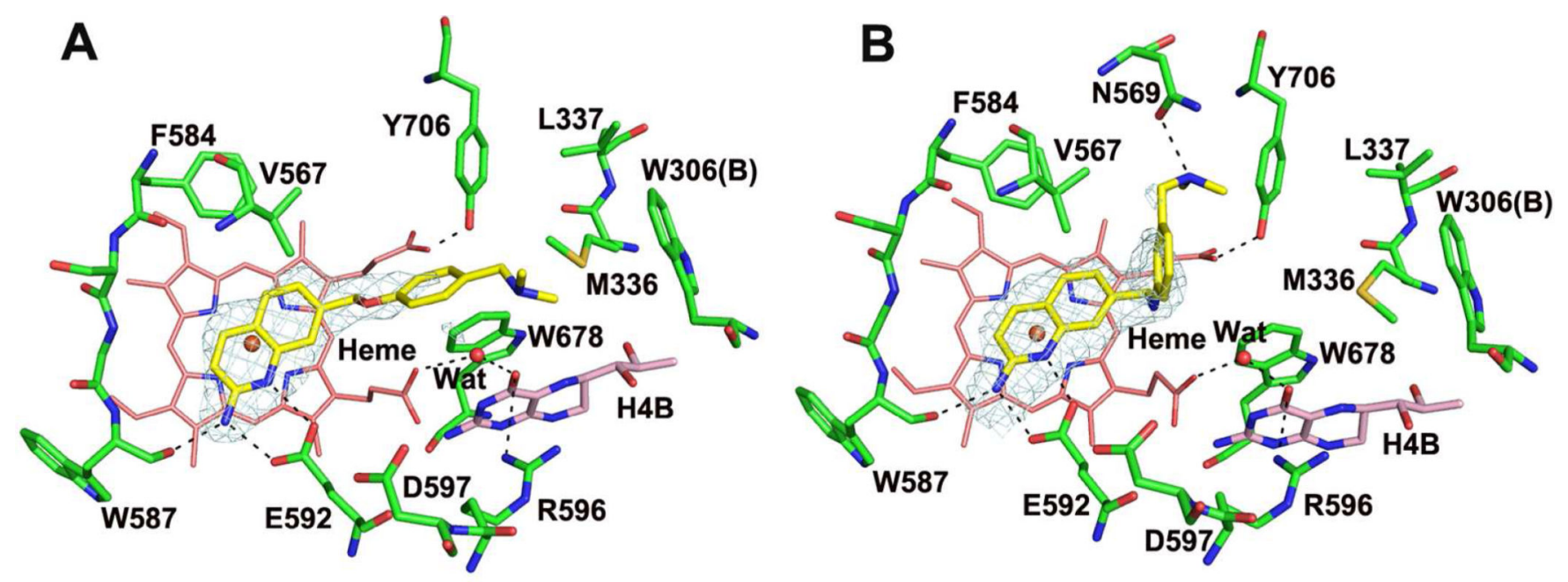

Figure 7.

Active site structure of $\mathbf{1 5}$ (A) or $\mathbf{1 7}$ (B) bound to rat nNOS. The omit Fo - Fc density map for the inhibitor is shown at the $2.5 \sigma$ contour level. Major hydrogen bonds are shown as dashed lines. 

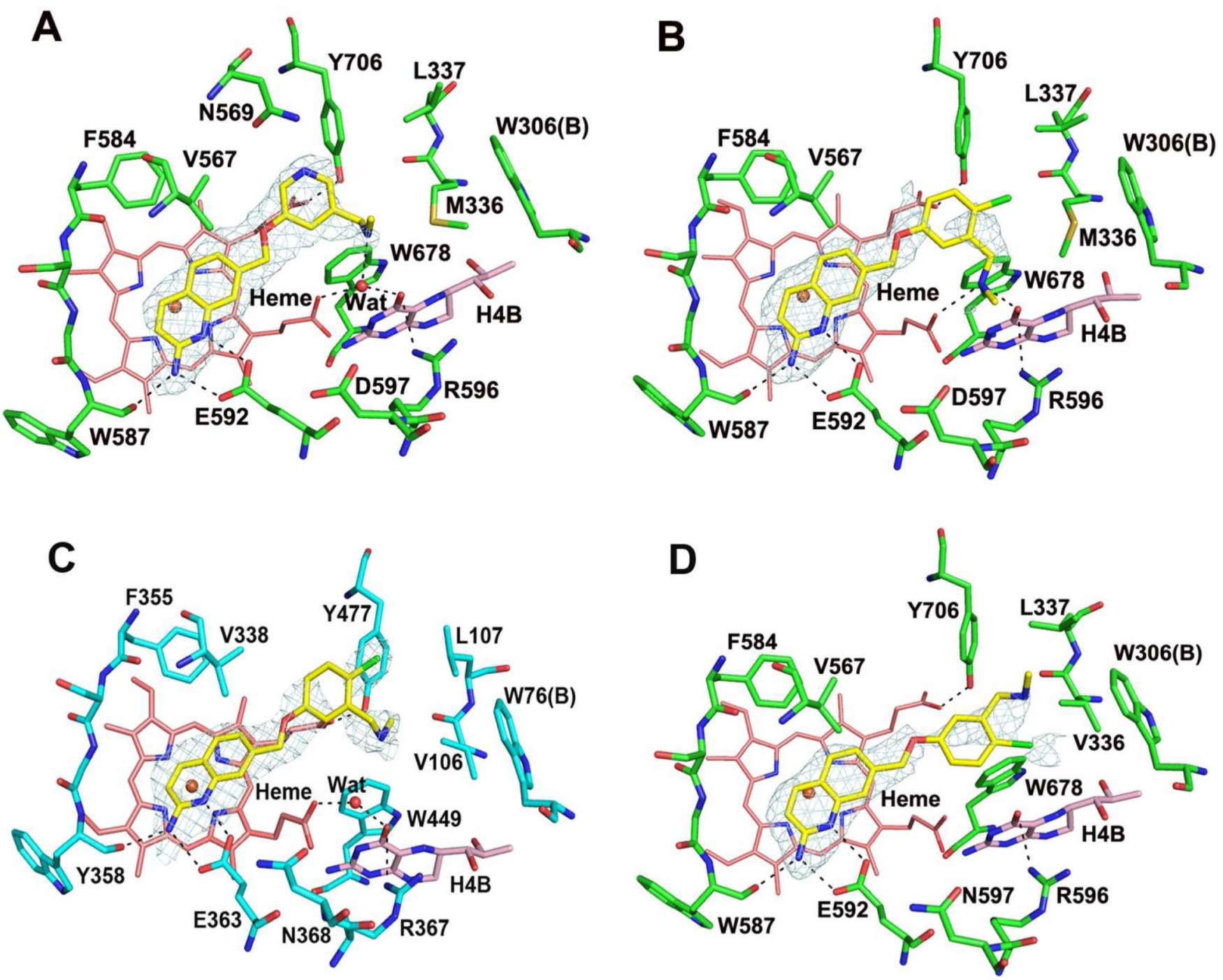

Figure 8.

Active site structure of $\mathbf{2 1}$ (A) or $\mathbf{2 0}$ (B) bound to rat nNOS, 20 bound to acetate-free eNOS (C), or 20 bound to rat nNOS D597N/M336V double mutant (D). The omit Fo - Fc density map for the inhibitor is shown at the $2.5 \sigma$ contour level. The dimethylamine of $\mathbf{2 0}$ displaces the water molecule bridging $\mathrm{H}_{4} \mathrm{~B}$ and heme in the WT nNOS, but not in the acetate-free eNOS or the nNOS double mutant structures. Major hydrogen bonds are shown as dashed lines. 

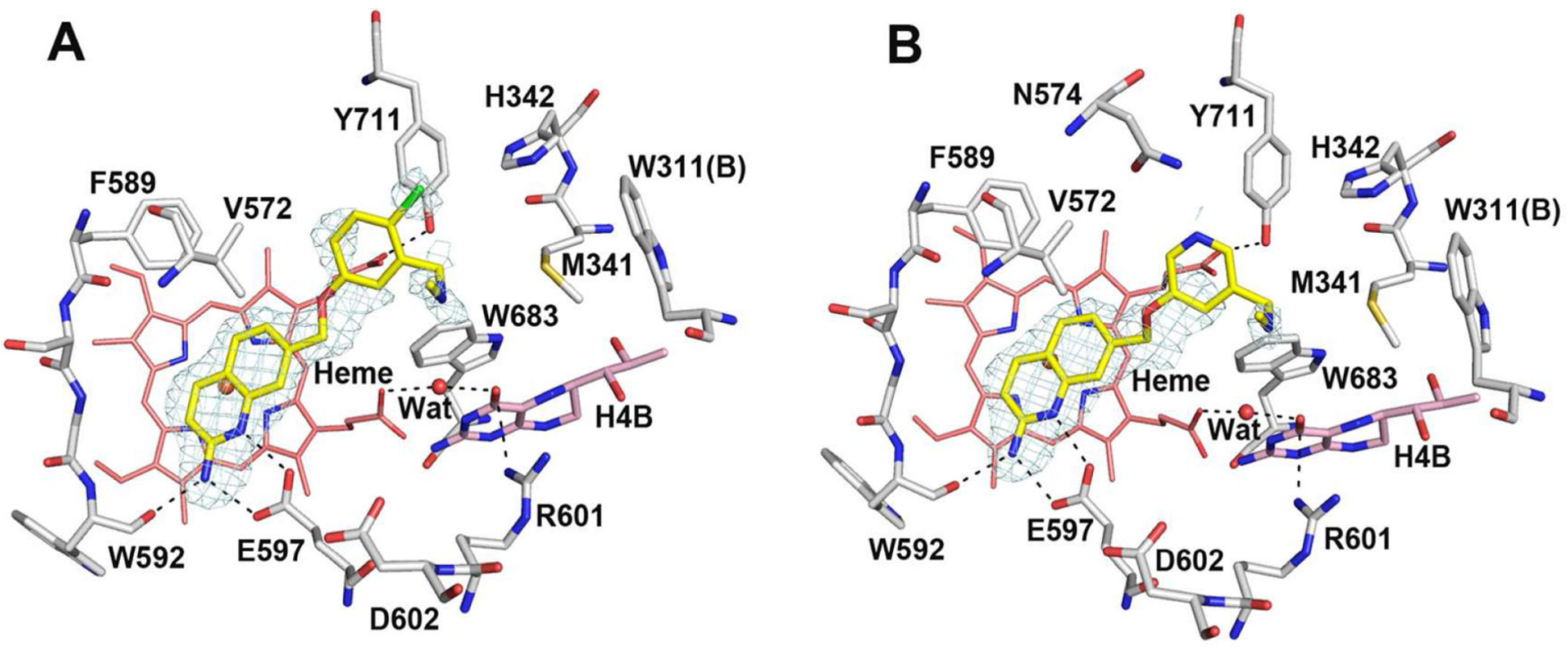

Figure 9.

Active site structure of $\mathbf{2 0}$ (A) or $\mathbf{2 1}$ (B) bound to human nNOS. The omit Fo - Fc density map for the inhibitor is shown at the $2.5 \sigma$ contour level. Major hydrogen bonds are shown as dashed lines. 
<smiles>Cc1ccc2ccc(C)nc2c1</smiles>

23

24
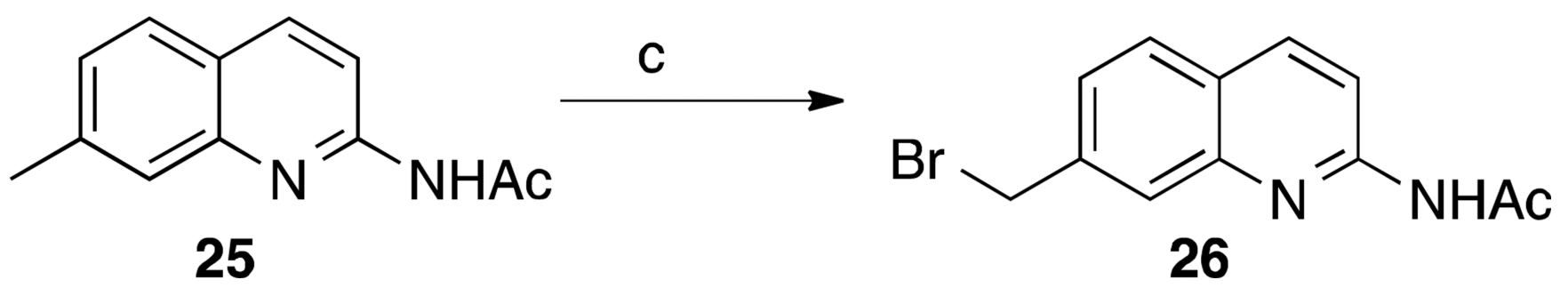

Scheme $1^{\text {a }}$

aReagents and conditions: (a) LHMDS, $\mathrm{Pd}_{2}(\mathrm{dba})_{3}$, DavePhos, THF/dioxane, $100{ }^{\circ} \mathrm{C}$; (b) $\mathrm{N}$ acetylimidazole, THF, reflux; (c) NBS, $\left(\mathrm{PhCO}_{2}\right)_{2}$, benzene, reflux. 

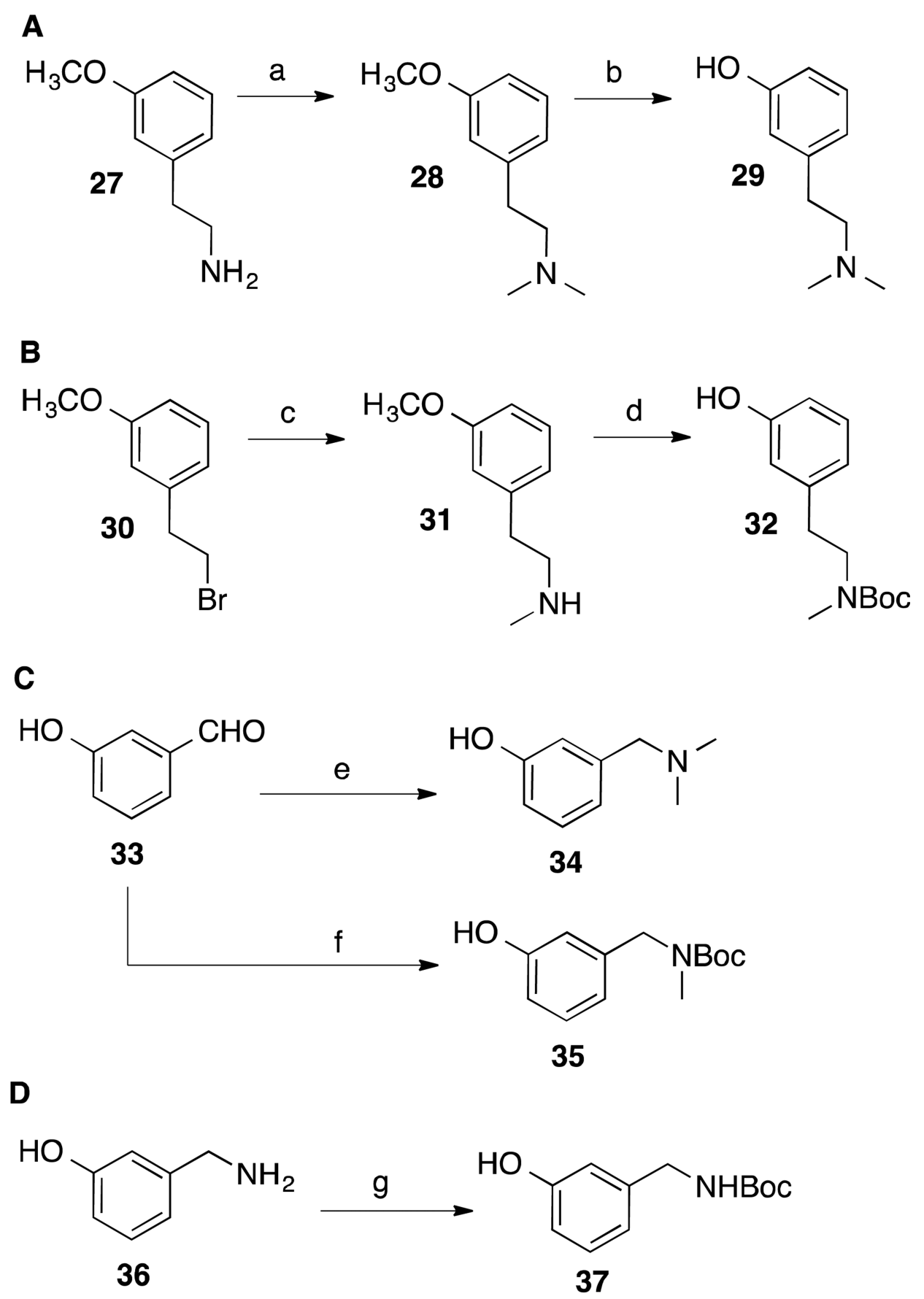

Scheme $2^{\mathbf{a}}$

aReagents and conditions: (a) formalin, formic acid, DMF, $60{ }^{\circ} \mathrm{C}-120^{\circ} \mathrm{C}, 5 \mathrm{~h}$; (b) $48 \%$ $\mathrm{HBr}$, AcoH, reflux; (c) $40 \% \mathrm{MeNH}_{2}$ in $\mathrm{H}_{2} \mathrm{O}$, THF/ $\mathrm{H}_{2} \mathrm{O}$, r.t.; (d) i. $48 \% \mathrm{HBr}$, HOAc, reflux, ii. $\mathrm{Boc}_{2} \mathrm{O}, \mathrm{Et}_{3} \mathrm{~N}$, THF, r.t.; (e) i. $\mathrm{Me}_{2} \mathrm{NH}-\mathrm{HCI}, \mathrm{Et}_{3} \mathrm{~N}, \mathrm{CHCl}_{3} / \mathrm{MeOH}_{2} \mathrm{Na}_{2} \mathrm{SO}_{4}$, r.t., ii. $\mathrm{Na}(\mathrm{OAc})_{3} \mathrm{BH}$, r.t., (f) $i$. $\mathrm{MeNH}_{2}$ in THF, cat. $\mathrm{AcOH}, \mathrm{CHCl}_{3} / \mathrm{MeOH}, \mathrm{Na}_{2} \mathrm{SO}_{4}$, r.t.; ii. $\mathrm{NaBH}_{4}$, $\mathrm{MeOH}, 0{ }^{\circ} \mathrm{C}$ - r.t., iii. $\mathrm{Boc}_{2} \mathrm{O}$, THF, r.t.; (g) $\mathrm{Boc}_{2} \mathrm{O}$, THF, $0{ }^{\circ} \mathrm{C}$ - r.t. 
A

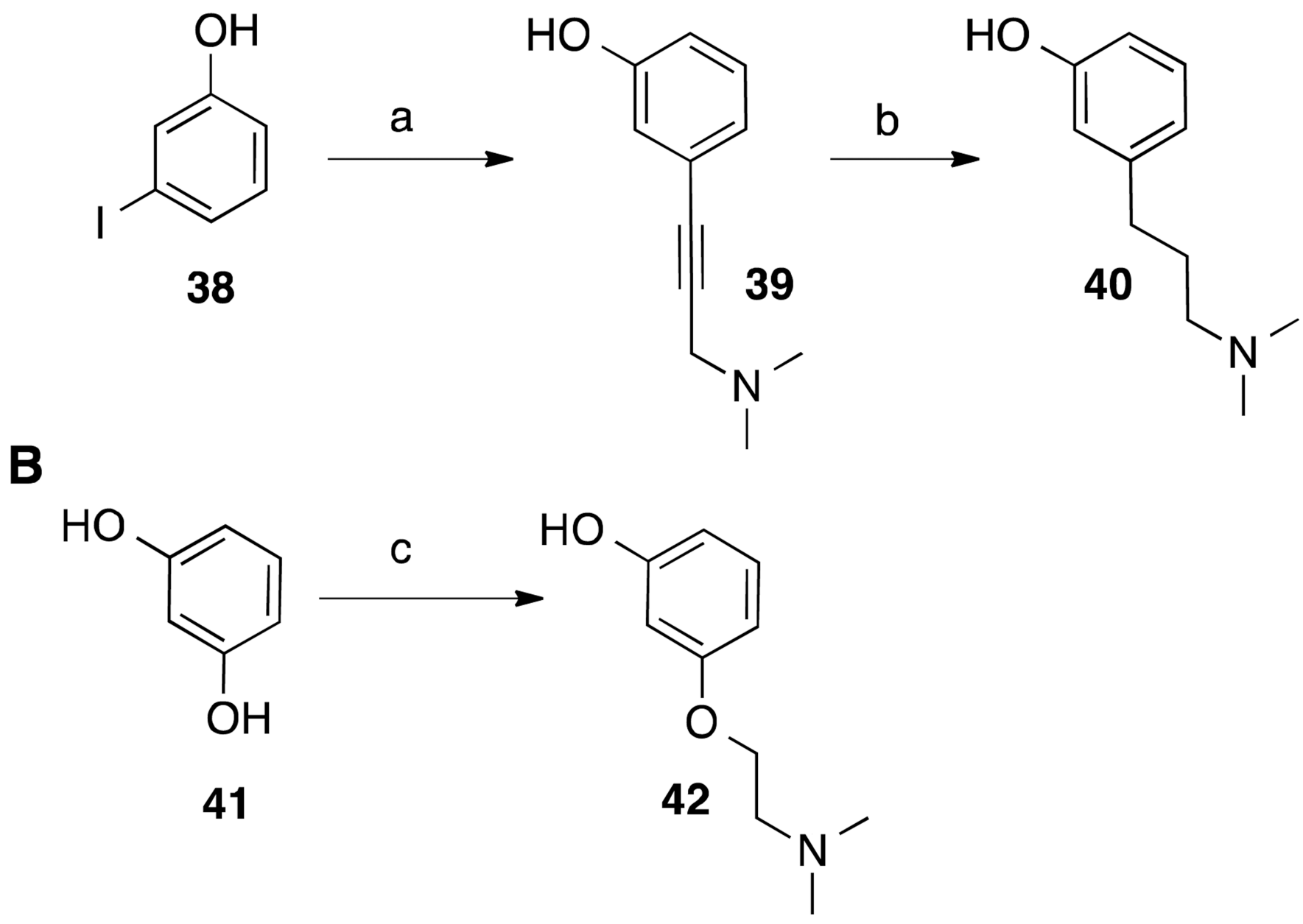

Scheme $3^{\text {a }}$

aReagents and conditions: (a) $N, N$-dimethylpropargylamine $\mathrm{Cul}$ (10 mol\%), $\mathrm{Pd}\left(\mathrm{PPh}_{3}\right)_{4}(5$ mol\%), THF/Et $3 \mathrm{~N}$, r.t.; (b) $\mathrm{H}_{2}, \mathrm{Pd} / \mathrm{C}, \mathrm{MeOH}$, r.t.; (c) $N, N$-dimethylethanolamine, $\mathrm{PPh}_{3}$, DEAD, THF, $0{ }^{\circ} \mathrm{C}$; r.t. 


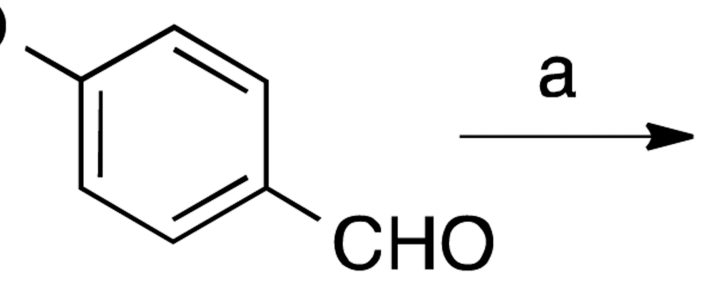

43

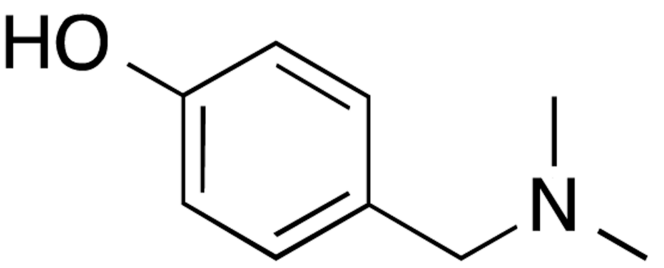

44

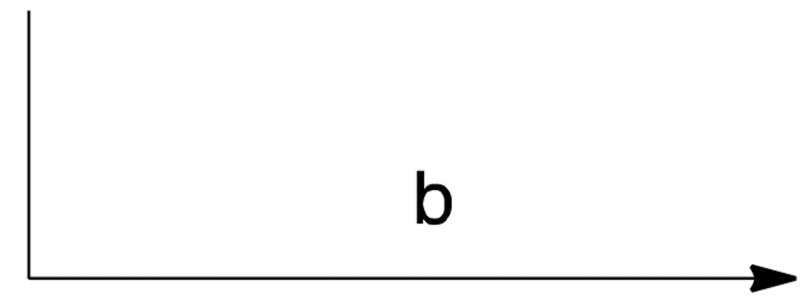

$\mathrm{HO}$

Scheme $4^{\text {a }}$

aReagents and conditions: (a) $i$. $\mathrm{Me}_{2} \mathrm{NH}-\mathrm{HCl}, \mathrm{Et}_{3} \mathrm{~N}, \mathrm{Na}_{2} \mathrm{SO}_{4}, \mathrm{CHCl}_{3} / \mathrm{MeOH}$, r.t.; $i$.

$\mathrm{Na}(\mathrm{OAc})_{3} \mathrm{BH}$, r.t., (b) $i$. $\mathrm{MeNH}_{2}$ in THF, $\mathrm{CHCl}_{3} / \mathrm{MeOH}, \mathrm{Na}_{2} \mathrm{SO}_{4}$, $\mathrm{AcOH}$, r.t., ii. $\mathrm{NaBH}_{4}$, $\mathrm{MeOH}, 0^{\circ} \mathrm{C}$ - r.t., iii. $\mathrm{Boc}_{2} \mathrm{O}$, THF, r.t. 


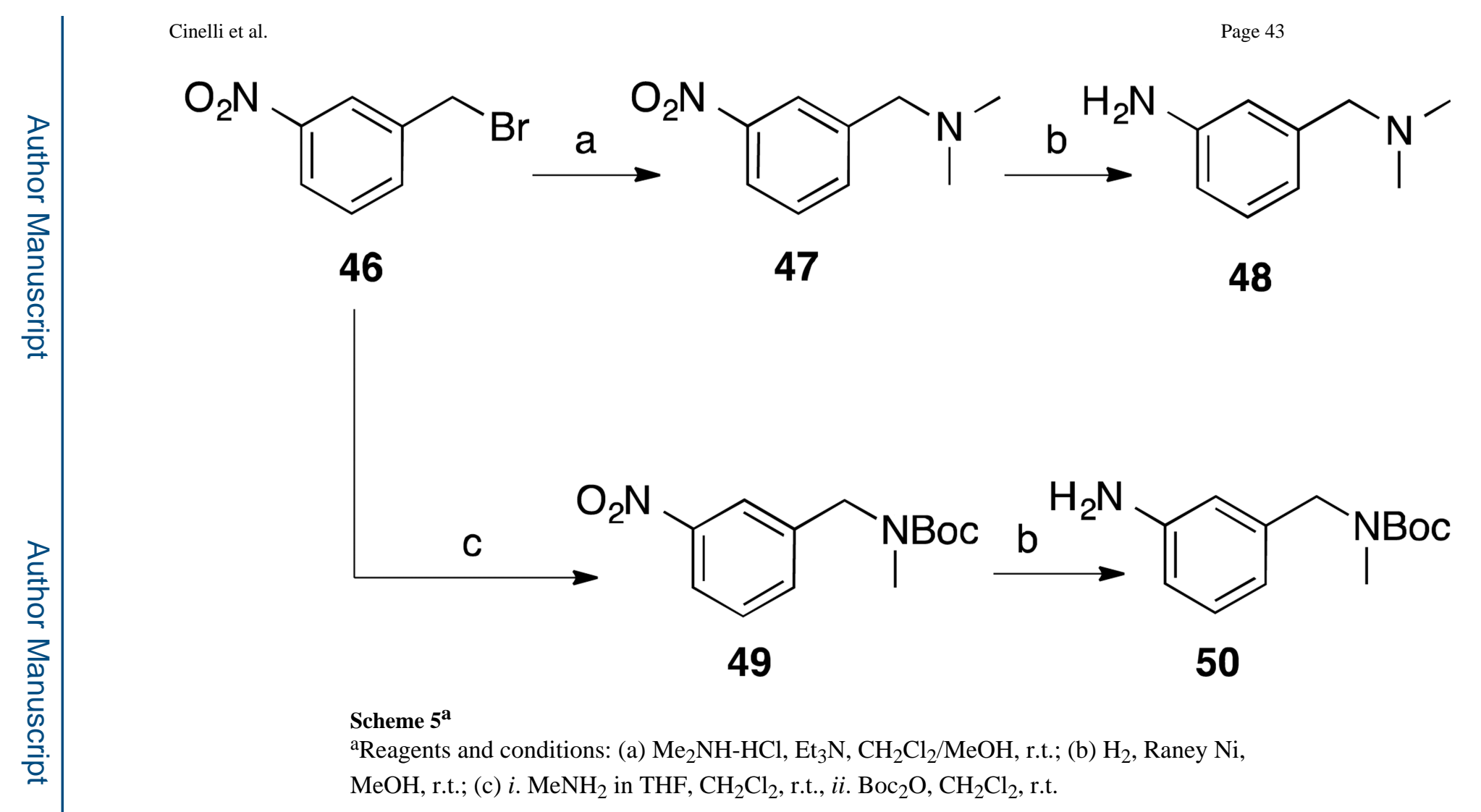


A<smiles>[R7]C(=O)c1cc(O)ccc1[R2]</smiles>

$\mathrm{R}_{1}=\mathrm{H}, \mathrm{R}_{2}=\mathrm{F}, \mathbf{5 1}$

$\mathrm{R}_{1}=\mathrm{H}, \mathrm{R}_{2}=\mathrm{F}, 54$

$\mathrm{R}_{1}=\mathrm{H}, \mathrm{R}_{2}=\mathrm{Cl}, 52$

$\mathrm{R}_{1}=\mathrm{H}, \mathrm{R}_{2}=\mathrm{Cl}, 55$

$\mathrm{R}_{1}=\mathrm{CH}_{3}, \mathrm{R}_{2}=\mathrm{H}, 53$

$\mathrm{R}_{1}=\mathrm{CH}_{3}, \mathrm{R}_{2}=\mathrm{H}, 56$

B
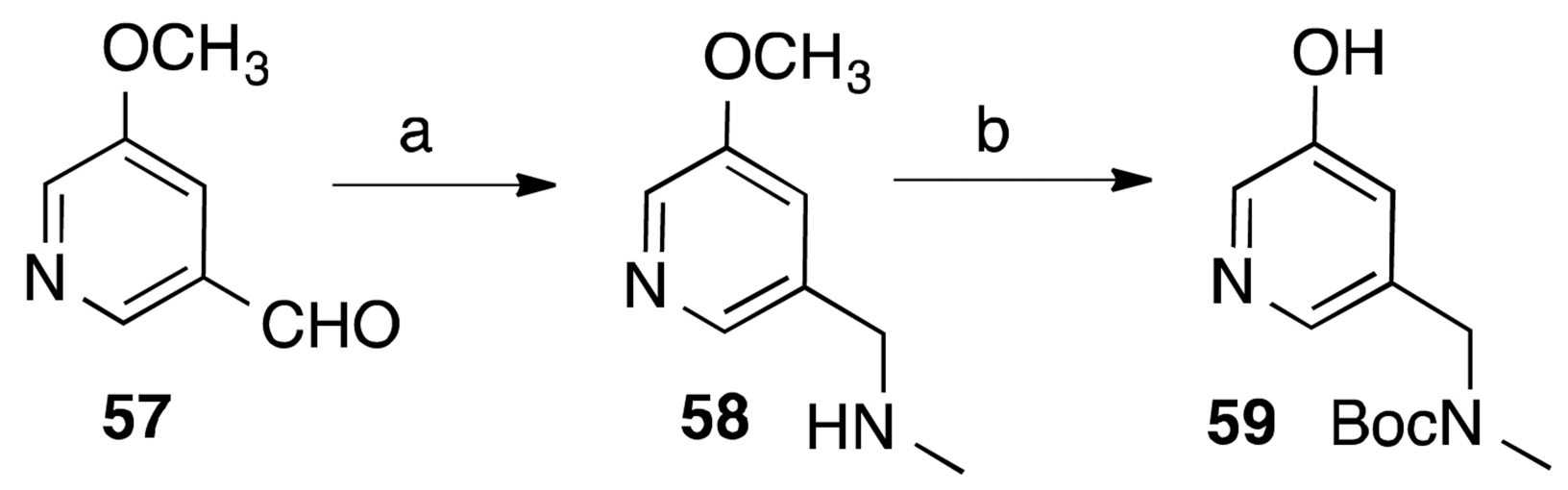

Scheme $6^{\mathbf{a}}$

aReagents and conditions: (a) $i$. $\mathrm{MeNH}_{2}$ in THF, cat. $\mathrm{AcOH}, \mathrm{CHCl}_{3} / \mathrm{MeOH}, \mathrm{Na}_{2} \mathrm{SO}_{4}$, r.t, ii. $\mathrm{NaBH}_{4}, \mathrm{MeOH}, 0^{\circ} \mathrm{C}$ - r.t., iii. $\mathrm{Boc}_{2} \mathrm{O}$, THF, r.t.; (b) $i . \mathrm{HBr} / \mathrm{H}_{2} \mathrm{O}, \mathrm{AcOH}, 130{ }^{\circ} \mathrm{C}$, ii. $\mathrm{Et}_{3} \mathrm{~N}$, $\mathrm{Boc}_{2} \mathrm{O}, \mathrm{THF} / \mathrm{MeOH}$, r.t. 


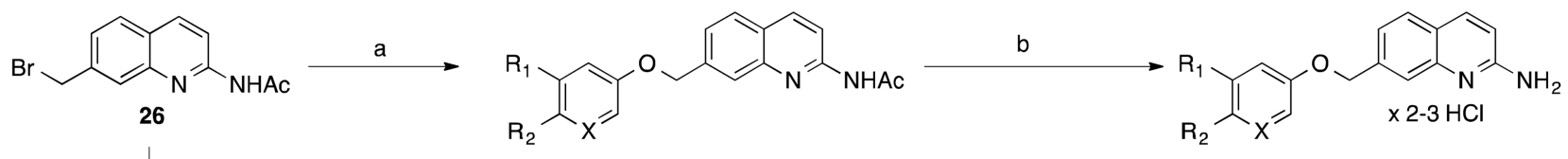

c

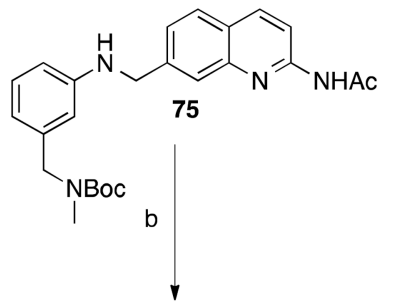

When $\mathrm{X}=\mathrm{CH}$ :

$\mathrm{R}_{2}=\mathrm{H}, \mathrm{R}_{1}=ح^{\mathrm{N}} \backslash, 60$

When $\mathrm{X}=\mathrm{N}$ :

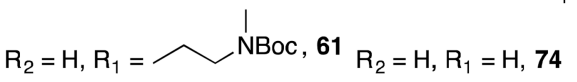

$R_{2}=H, R_{1}=\widehat{N}_{N^{\prime}}^{\prime}, 62$

$\mathrm{R}_{2}=\mathrm{H}, \mathrm{R}_{1}=\widehat{\mathrm{NBoc}}_{\mathrm{I}} 63$

$\mathrm{R}_{2}=\mathrm{H}, \mathrm{R}_{1}=\widehat{\mathrm{NHBOC}}_{\mathrm{N}} 64$

$R_{2}=H, R_{1}=-N$

$\mathrm{R}_{2}=\mathrm{H}, \mathrm{R}_{1}=\widehat{N}_{\mathrm{N}^{\prime}, 66}$

$\mathrm{R}_{2}=\mathrm{H}, \mathrm{R}_{1}=-\mathrm{O}_{\mathrm{I}}^{N^{\prime}, 67}$

$R_{1}=H, R_{2}=\widehat{N}_{N^{\prime}}, 68$

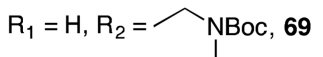

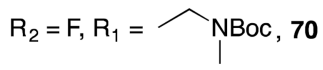

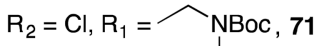

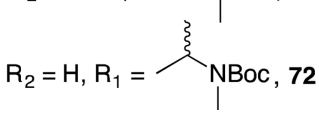

$R_{2}=H, R_{1}=N^{\prime}, 73$

$\mathrm{R}_{2}=\mathrm{H}, \mathrm{R}_{1}=\overbrace{}^{\mathrm{N}}, 6 \quad \mathrm{R}_{2}=\mathrm{H}, \mathrm{R}_{1}=\overbrace{\mathrm{N}}^{\prime}, 21$

$\mathrm{R}_{2}=\mathrm{H}, \mathrm{R}_{1}=\mathrm{H}_{\mathrm{N}}^{\mathrm{H}}, 7 \quad \mathrm{R}_{2}=\mathrm{H}, \mathrm{R}_{1}=\mathrm{H}, 11$

$R_{2}=H, R_{1}=\widehat{I}_{N^{\prime}, 8}^{\prime}$

$\mathrm{R}_{2}=\mathrm{H}, \mathrm{R}_{1}=\widehat{\mathrm{H}}_{\mathrm{H}}^{\prime}, 9$

$\mathrm{R}_{2}=\mathrm{H}, \mathrm{R}_{1}=\widehat{\mathrm{NH}_{2}, 10}$

$R_{2}=H, R_{1}=-\stackrel{N}{N} \backslash, 12$

$\mathrm{R}_{2}=\mathrm{H}, \mathrm{R}_{1}=\widehat{N}_{\mathrm{N}^{\prime}, 13}$

$R_{2}=H, R_{1}=-\overbrace{\mid}^{N^{\prime}, 14}$

$R_{1}=H, R_{2}=\widehat{N}_{i}^{\prime}, 15$

$R_{1}=H, R_{2}=\widehat{N}_{\mathrm{H}^{\prime}}^{\prime}, 16$

$R_{2}=F, R_{1}=\widehat{N}_{\mathrm{H}^{\prime}}^{\prime}, 19$

$\mathrm{R}_{2}=\mathrm{Cl}, \mathrm{R}_{1}=\widehat{\mathrm{N}}_{\mathrm{N}^{\prime}, \mathbf{2 0}}$

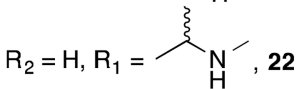

Scheme $7^{\mathbf{a}}$

${ }^{\text {a}}$ Reagents and conditions: (a) $i$. Phenols $29,32,34,35,37,40,42,44,45,54-56,59,3-$

(dimethylamino)phenol, or 3-hydroxypyridine $\mathrm{NaH}, \mathrm{DMF}, 0{ }^{\circ} \mathrm{C}$, ii. 26 (in DMF), $0{ }^{\circ} \mathrm{C}$; (b) $i$. $\mathrm{K}_{2} \mathrm{CO}_{3}$, $\mathrm{MeOH}$, reflux, ii. $\mathrm{HCl} / \mathrm{MeOH}$, ether, r.t., or TFA/DCM (for 72), after isolation, 5 min-overnight; 50 (2.5 eq.), cat. $\mathrm{Kl}$, $\mu$ wave, $\mathrm{MeCN}, 110{ }^{\circ} \mathrm{C}$. 


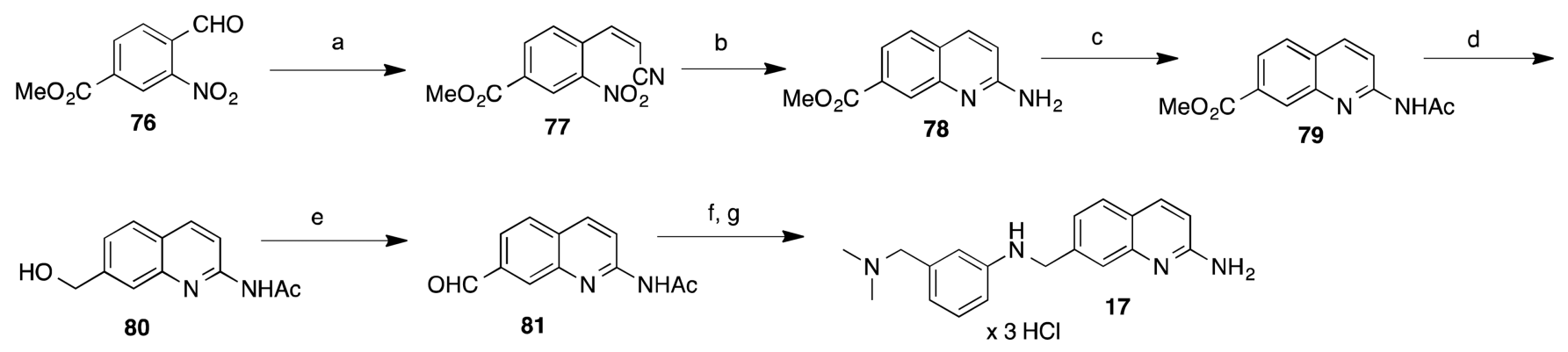

\section{Scheme $8^{\text {a }}$}

aReagents and conditions: (a) (triphenylphosphoranylidene)acetonitrile (slow addition), $\mathrm{CH}_{2} \mathrm{Cl}_{2},-10{ }^{\circ} \mathrm{C}$ (b) Fe powder, DMF/AcOH, $100{ }^{\circ} \mathrm{C}$; (c) $\mathrm{N}$-acetylimidazole cat. DMAP, dioxane, $100{ }^{\circ} \mathrm{C}$; (d) $\mathrm{LiAlH}_{4}$ (1.5 eq.), THF, $-10{ }^{\circ} \mathrm{C}-0{ }^{\circ} \mathrm{C}$; (e) $\mathrm{PPh}_{3}, \mathrm{CBr}_{4}$, THF, $0{ }^{\circ} \mathrm{C}$ - r.t.; (e) Dess-Martin periodinane, $\mathrm{CH}_{2} \mathrm{Cl}_{2}$, r.t.; (f) $i .{ }_{48}, \mathrm{EtOH}, \mathrm{AcOH}, \mathrm{Na}_{2} \mathrm{SO}_{4}, 60^{\circ} \mathrm{C}$, ii. $\mathrm{NaBH}_{4}$, r.t., (g) $i$. $\mathrm{K}_{2} \mathrm{CO}_{3}$, $\mathrm{MeOH}$, reflux; ii. $\mathrm{HCl} / \mathrm{MeOH}$, ether, r.t. (after iso;ation). 


\section{Table 2}

Inhibition of rat and human nNOS by select compounds ${ }^{a}$

\begin{tabular}{cccc}
\hline & \multicolumn{2}{c}{$\boldsymbol{K}_{\mathrm{i}}(\boldsymbol{\mu M}) \boldsymbol{a}$} & \\
\cline { 2 - 3 } Compound & $\begin{array}{c}\text { Selectivity } \\
(\text { Rat/Human) }\end{array}$ \\
\cline { 2 - 3 } & Rat nNOS & $\begin{array}{c}\text { Human } \\
\text { nNOS }\end{array}$ & \\
\hline $\mathbf{1}$ & 0.049 & 0.318 & 6.5 \\
$\mathbf{2}$ & 0.066 & 0.440 & 6.7 \\
$\mathbf{6}$ & 0.468 & 1.86 & 4.0 \\
$\mathbf{8}$ & 0.179 & 0.855 & 4.8 \\
$\mathbf{9}$ & 0.142 & 0.911 & 6.4 \\
$\mathbf{1 5}$ & 0.283 & 1.08 & 3.8 \\
$\mathbf{1 7}$ & 0.375 & 0.657 & 1.8 \\
$\mathbf{2 0}$ & 0.058 & 0.295 & 5.1 \\
$\mathbf{2 1}$ & 0.043 & 0.507 & 11.8 \\
\hline
\end{tabular}

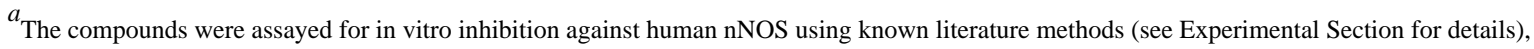
and $K_{\mathrm{i}}$ values are calculated directly from IC 50 values. IC 50 values are the average of at least two replicates from 7-9 data points; all experimental standard error values are less than $12 \%$ and all correlation coefficients are good $\left(\mathrm{R}^{2}>0.87\right)$. Selectivity values are ratios of respective $K_{\mathrm{i}}$ values; rat nNOS $K_{\mathrm{i}}$ values are from Table 1. 


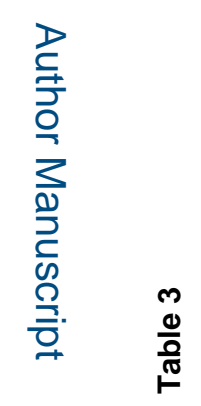

로을
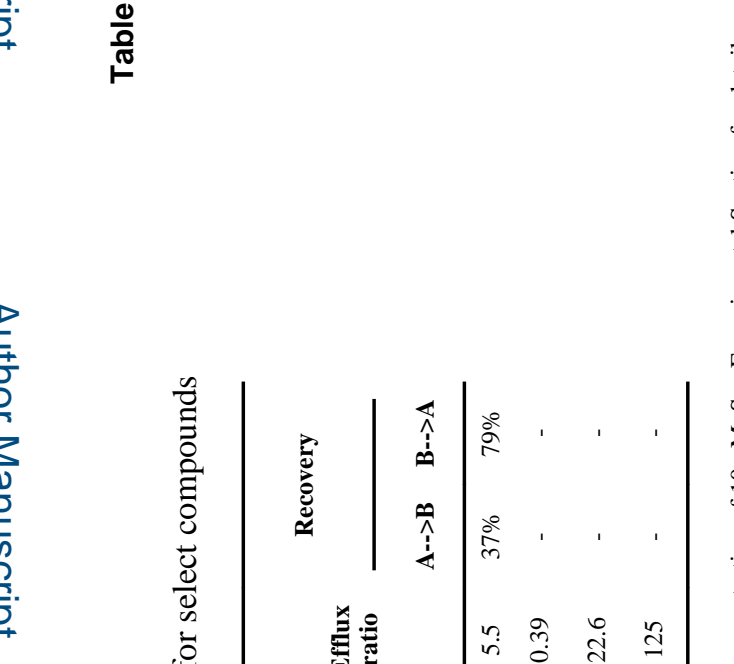

$\frac{10}{10}$
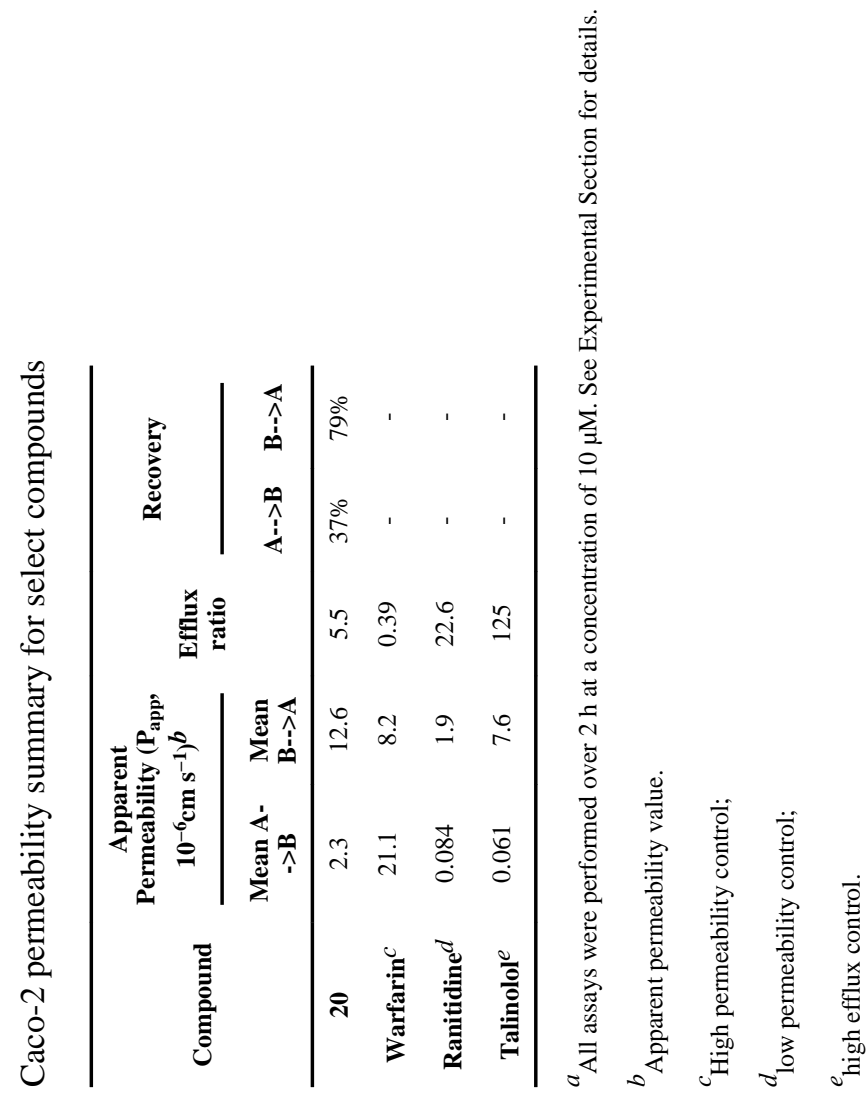

J Med Chem. Author manuscript; available in PMC 2016 November 12. 


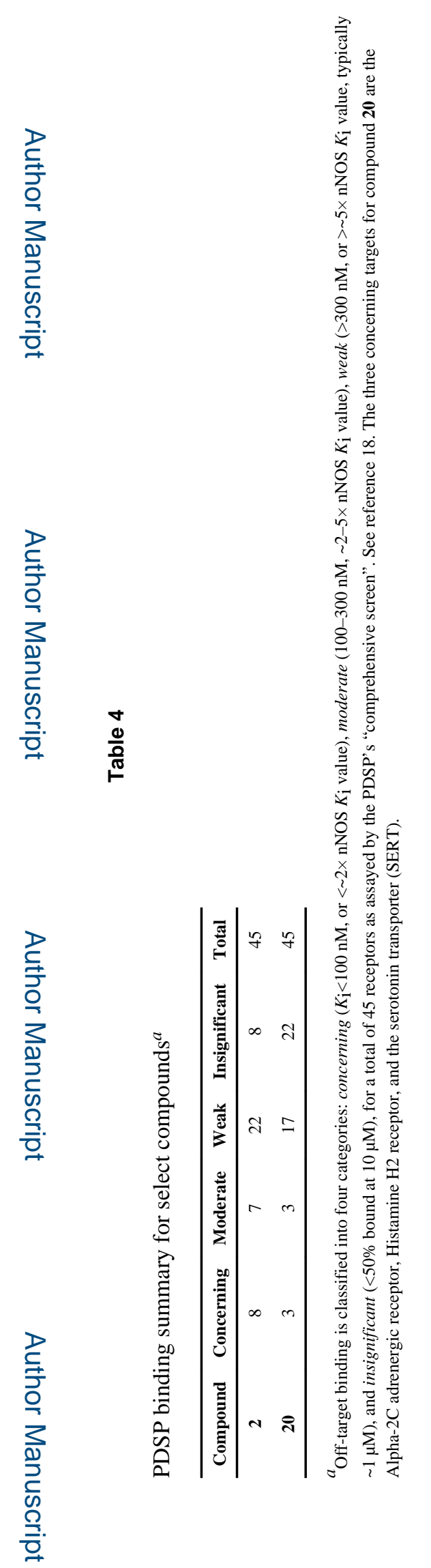

J Med Chem. Author manuscript; available in PMC 2016 November 12. 